\title{
The 2007 HMDA Data
}

Robert B. Avery, Kenneth P. Brevoort, and Glenn B. Canner, of the Division of Research and Statistics, prepared this article. Cheryl R. Cooper, Christa N. Gibbs, Rebecca Tsang, and Sean Wallace provided research assistance.

The Home Mortgage Disclosure Act of 1975 (HMDA) requires most mortgage lending institutions with offices in metropolitan areas to publicly disclose information about their home-lending activity. The information includes characteristics of the home mortgages that lenders originate or purchase during a calendar year, the geographic location of the properties related to these loans, and demographic and other information about the borrowers. ${ }^{1}$ The disclosures are intended not only to help the public determine whether institutions are adequately serving their communities' housing finance needs but also to facilitate enforcement of the nation's fair lending laws and to inform investment in both the public and private sectors.

Under the 1975 act, the Federal Reserve Board implements the provisions of HMDA through regulation. $^{2}$ In addition, the Federal Financial Institutions Examination Council (FFIEC) is responsible for collecting the HMDA data and facilitating public access to the information. ${ }^{3}$ Each September, the FFIEC releases summary tables pertaining to lending activity from the previous calendar year for each reporting lender and an aggregation of home-lending activity by metropolitan statistical area (MSA). ${ }^{4}$ The FFIEC also makes available a consolidated data file contain-

1. A description of the items reported under HMDA is provided in appendix A.

2. HMDA is implemented by Regulation C (12 C.F.R. pt. 203) of the Federal Reserve Board. More information about the regulation is available at www.federalreserve.gov.

3. The FFIEC (www.ffiec.gov) was established by federal law in 1979 as an interagency body to prescribe uniform examination procedures, and to promote uniform supervision, among the federal agencies responsible for the examination and supervision of financial institutions. The member agencies are the Board of Governors of the Federal Reserve System, the Federal Deposit Insurance Corporation, the National Credit Union Administration, the Office of the Comptroller of the Currency, and the Office of Thrift Supervision.

4. For the 2007 data, the FFIEC prepared more than 63,000 MSA-specific reports on behalf of reporting institutions. These and other reports are made available to the public by the FFIEC. ing virtually all the reported information for each lending institution. ${ }^{5}$

The HMDA data consist of information reported by about 8,600 home lenders, including all of the nation's largest mortgage originators. The loans reported are estimated to represent about 80 percent of all home lending nationwide; thus, they likely provide a broadly representative picture of home lending in the United States.

This article presents key findings from the 2007 HMDA data. In doing so, it highlights the notable changes in relationships that are revealed when the 2007 data are compared with data from earlier years. ${ }^{6}$ Because of the importance of the loan-pricing information included in the HMDA data and because of the recent turmoil in the residential mortgage market, particularly the higher-priced segment of the market, much of the focus here is on the data pertaining to that market segment. ${ }^{7}$

5. The only reported items not included in the data made available to the public are the date of application and the date on which action was taken on the application. These items are withheld to help ensure that the individuals involved in the application cannot be identified.

6. Previously published assessments include Robert B. Avery, Kenneth P. Brevoort, and Glenn B. Canner (2007), "The 2006 HMDA Data," Federal Reserve Bulletin, vol. 93 (December 21), pp. A73A109; Robert B. Avery, Kenneth P. Brevoort, and Glenn B. Canner (2006), "Higher-Priced Home Lending and the 2005 HMDA Data," Federal Reserve Bulletin, vol. 92 (September 8), pp. A123-66; and Robert B. Avery, Glenn B. Canner, and Robert E. Cook (2005), "New Information Reported under HMDA and Its Application in Fair Lending Enforcement," Federal Reserve Bulletin, vol. 91 (Summer), pp. 344-94.

7. Borrowers in the higher-priced market segment generally fall into one of two market categories- "subprime" or "near prime" (sometimes referred to as "alt-A"). Individuals in the subprime category generally pay the highest prices because they tend to pose the greatest credit or prepayment risk. Statistics prepared by the lending industry do not characterize lending as higher priced but rather use the terms subprime or alt-A. Thus, when presenting data from industry sources on loan performance or other aspects of the mortgage market, this article will often refer to data on the subprime, alt-A, or prime lending market.

Mortgages with annual percentage rates (APRs, which encompass interest rates and fees) above designated thresholds are referred to here as "higher-priced loans"; all other loans are referred to as "lower priced." For loans with spreads above designated thresholds, revised Regulation $\mathrm{C}$ requires the reporting of the spread between the APR on a loan and the rate on Treasury securities of comparable maturity. The thresholds for reporting differ by lien status: 3 percentage points for first liens and 5 percentage points for junior, or subordinate, liens.

Further details are in note 12, p. A126, of Avery, Brevoort, and Canner, "Higher-Priced Home Lending and the 2005 HMDA Data." 


\section{TURMOIL IN THE MORTGAGE MARKET}

Both primary and secondary mortgage markets experienced considerable stress in 2007, a condition that has continued into 2008. ${ }^{8}$ Delinquency rates on higher-priced home loans, particularly those with adjustable-rate features, first began to increase notably in 2006; those rates then rose sharply during 2007 and far outpaced the performance problems that also emerged in the lower-priced segment of the market. ${ }^{9}$

One consequence of deteriorating loan performance and widespread declines in home values was a sharp contraction in 2007 in the willingness of lenders and investors to offer loans to higher-risk borrowers or, in some cases, to offer certain loan products that entailed features associated with elevated credit risk. ${ }^{10}$ Moreover, to the extent that credit was still available, loan prices rose sharply, largely because of concerns about repayment prospects. In addition, many lenders whose business models relied on a robust secondary market to purchase the loans they originated were forced to cease or curtail operations, as they could no longer obtain funds to operate or find investors willing to purchase their loan originations.

Difficulties in the higher-priced portion of the mortgage market spilled over to other market segments, including the market for loans for large amounts (the so-called jumbo market), in which credit spreads widened substantially. The widening of spreads led to higher interest rates on such loans, which effectively reduced credit availability. ${ }^{11}$

The 2007 HMDA data reflect the difficulties in the housing and mortgage markets. Many reporting institutions experienced a sharp reduction in loan applica-

8. See, for example, Randall S. Kroszner (2007), "The Challenges Facing Subprime Mortgage Borrowers," speech delivered at the Consumer Bankers Association 2007 Fair Lending Conference, Washington, November 5, www.federalreserve.gov/newsevents/speech/ kroszner20071105a.htm.

9. Data from LoanPerformance, a subsidiary of First American CoreLogic, Inc., show that 20.4 percent of the subprime loans with adjustable-rate features were seriously delinquent at the end of 2007. By comparison, 8.2 percent of fixed-rate subprime loans, 1.0 percent of fixed-rate prime loans, and 4.2 percent of adjustable-rate prime loans were seriously delinquent at the end of that year.

10. Industry sources indicate that the dollar amount of originations of subprime loans fell 68 percent from 2006 to 2007, to a level of only $\$ 191$ billion. Subprime loan originations in 2007 were the smallest since 2001. See Inside Mortgage Finance (2008), The 2008 Mortgage Market Statistical Annual, vol. 1: The Primary Market (Bethesda, Md.: Inside Mortgage Finance Publications).

11. Jumbo loans are loans that exceed the size limits set for loans that Fannie Mae and Freddie Mac are permitted to purchase (conforming loans). Fannie Mae and Freddie Mac are government-sponsored enterprises that focus on conventional loans that meet certain size limits and other underwriting criteria. Available data indicate that the dollar amount of originations of jumbo loans fell nearly 30 percent from 2006 to 2007. See Inside Mortgage Finance, The 2008 Mortgage Market Statistical Annual. tions and originations, particularly in the higherpriced segments of the mortgage market. Also, some lenders that had previously reported HMDA data ceased operations during 2007 and did not file a HMDA report even though they extended loans during part of that year. ${ }^{12}$ Although nonreporting by lenders that ceased operations affects the comprehensiveness of the HMDA data each year to some extent, nonreporting in 2007 had a much larger effect than in previous years. For 2007, many more lenders than in earlier years ceased operations because of a bankruptcy or other adverse business event, and the nonreporting institutions accounted for a significant minority of the loans originated in 2006 and an even larger share of the higher-priced loans made that year. Most important, the effects of nonreporting in the 2007 HMDA data amplified the measured decline in higher-priced lending from 2006. The amplification occurred because some of the lenders that ceased operations originated loans in 2007, and according to these institutions' lending profiles in 2006, a disproportionate share of those originations consisted of higher-priced loans. For this reason, some caution should be exercised in using the 2007 data to document the full extent of the disruptions in the higherpriced lending market in that year. The effects of nonreporting are difficult to quantify. This issue, among others, is addressed later in the article.

\section{GENERAL FINDINGS FROM THE 2007 HMDA DATA}

For 2007, lenders covered by HMDA reported information on 21.4 million applications for home loans. Almost all of the applications were for loans to be secured by one- to four-family (referred to here as "single family") houses (table 1). These applications resulted in more than 10.4 million loan extensions (data not shown in table). Lenders also reported information on 4.8 million loans that they had purchased from other institutions and on 433,000 requests for pre-approvals of home-purchase loans that had not resulted in a loan origination (data not shown in table); the pre-approval requests were turned down by the lender or were granted but not acted on by the applicant.

The total number of reported applications fell about 6.0 million, and the number of reported loans fell 3.5 million-or 22 percent and 25 percent,

12. As in earlier years, some institutions ceased operations because of a merger or acquisition. Lending by these institutions is reported, in most cases, by the acquiring institution on a consolidated basis or as two distinct filings. 
1. Home loan and reporting activity of lending institutions covered under the Home Mortgage Disclosure Act, 1990-2007 Number

\begin{tabular}{|c|c|c|c|c|c|c|c|c|}
\hline \multirow{3}{*}{ Year } & \multicolumn{6}{|c|}{$\begin{array}{l}\text { Applications received for home loans on } 1-4 \text { family properties, } \\
\text { and home loans purchased from another institution (millions) }\end{array}$} & \multirow{3}{*}{ Reporters } & \multirow{3}{*}{$\begin{array}{c}\text { Disclosure } \\
\text { reports }^{2}\end{array}$} \\
\hline & \multicolumn{4}{|c|}{ Applications } & \multirow{2}{*}{$\begin{array}{c}\text { Loans } \\
\text { purchased }\end{array}$} & \multirow[b]{2}{*}{ Total $^{1}$} & & \\
\hline & $\begin{array}{l}\text { Home } \\
\text { purchase }\end{array}$ & Refinance & $\begin{array}{c}\text { Home } \\
\text { improvement }\end{array}$ & Total $^{1}$ & & & & \\
\hline 1990. & 3.3 & 1.1 & 1.2 & 5.5 & 1.2 & 6.7 & 9,332 & 24,041 \\
\hline 1991. & 3.3 & 2.1 & 1.2 & 6.6 & 1.4 & 7.9 & 9,358 & 25,934 \\
\hline 1992 . & 3.5 & 5.2 & 1.2 & 10.0 & 2.0 & 12.0 & 9,073 & 28,782 \\
\hline 1993. & 4.5 & 7.7 & 1.4 & 13.6 & 1.8 & 15.4 & 9,650 & 35,976 \\
\hline 1994 . & 5.2 & 3.8 & 1.7 & 10.7 & 1.5 & 12.2 & 9,858 & 38,750 \\
\hline 1995. & 5.5 & 2.7 & 1.8 & 10.0 & 1.3 & 11.2 & 9,539 & 36,611 \\
\hline 1996. & 6.3 & 4.5 & 2.1 & 13.0 & 1.8 & 14.8 & 9,328 & 42,946 \\
\hline 1997. & 6.8 & 5.4 & 2.2 & 14.3 & 2.1 & 16.4 & 7,925 & 47,416 \\
\hline 1998 . & 8.0 & 11.4 & 2.0 & 21.4 & 3.2 & 24.7 & 7,836 & 57,294 \\
\hline 1999 . & 8.4 & 9.4 & 2.1 & 19.9 & 3.0 & 22.9 & 7,832 & 56,966 \\
\hline 2000 . & 8.3 & 6.5 & 2.0 & 16.8 & 2.4 & 19.2 & 7,713 & 52,776 \\
\hline 2001 . & 7.7 & 14.3 & 1.9 & 23.8 & 3.8 & 27.6 & 7,631 & 53,066 \\
\hline 2002 . & 7.4 & 17.5 & 1.5 & 26.4 & 4.8 & 31.2 & 7,771 & 56,506 \\
\hline 2003 . & 8.2 & 24.6 & 1.5 & 34.3 & 7.2 & 41.5 & 8,121 & 65,808 \\
\hline $2004 \ldots \ldots$ & 9.8 & 16.1 & 2.2 & 28.1 & 5.1 & 33.3 & 8,853 & 72,246 \\
\hline 2005 . & 11.7 & 15.9 & 2.5 & 30.2 & 5.9 & 36.0 & 8,848 & 78,193 \\
\hline 2006 . & 10.9 & 14.0 & 2.5 & 27.5 & 6.2 & 33.7 & 8,886 & 78,638 \\
\hline 2007. & 7.6 & 11.5 & 2.2 & 21.4 & 4.8 & 26.2 & 8,610 & 63,055 \\
\hline
\end{tabular}

NOTE: Here and in all subsequent tables, components may not sum to totals because of rounding, and, except as noted, applications exclude requests for pre-approval that were denied by the lender or were accepted by the lender but not acted upon by the borrower. In this article, applications are defined as being for a loan on a specific property; they are thus distinct from requests for pre-approval, which are not related to a specific property.

1. Applications for multifamily homes are included only in the total columns; for 2007, these applications numbered 54,232.

respectively_from 2006 (2006 data not shown in tables). Lending for both home purchase and refinancing fell as slower house price appreciation and, in some areas, outright declines in property values diminished the attractiveness of buying and selling properties or limited opportunities to refinance outstanding loans. The imposition of tighter underwriting standards, an increase in mortgage interest rates, and the elimination of some loan products used to stretch affordability also contributed to the reduction in lending. Finally, a portion of the decline in lending activity was due to the nonreporting of loans made by institutions that reported data for 2006 but discontinued operations during 2007.

\section{Reporting Institutions}

For 2007, 8,610 institutions reported under HMDA: 3,910 commercial banks, 929 savings institutions (savings and loans and savings banks), 2,019 credit unions, and 1,752 mortgage companies (table 2). In total, the number of reporting institutions fell about 3 percent from 2006, primarily because of a relatively large decline in the number of independent mortgage companies - that is, mortgage companies that were neither subsidiaries of depository institutions nor
2. A report covers the mortgage lending activity of a lender in a single metropolitan statistical area in which it had an office during the year.

SOURCE: Here and in the subsequent tables and figure except as noted, Federal Financial Institutions Examination Council, data reported under the Home Mortgage Disclosure Act (www.ffiec.gov/hmda).

affiliates of bank or savings association holding companies that reported data.

In total, 169 institutions that reported 2006 data did not report data pertaining to 2007 lending activity (these institutions ceased operations and were not merged into, or acquired by, another reporting entity). Some of the institutions that did not report were high-volume originators. In the aggregate, these nonreporting institutions accounted for about 2.4 million loans or applications that did not result in a credit extension, or about 7 percent of all the loan and

2. Distribution of reporters covered by the Home Mortgage Disclosure Act, by type of institution, 2006-07

\begin{tabular}{|c|c|c|c|c|}
\hline \multirow{2}{*}{ Type } & \multicolumn{2}{|c|}{2006} & \multicolumn{2}{|c|}{2007} \\
\hline & Number & Percent & Number & Percent \\
\hline Depository institution & & & & \\
\hline Commercial bank .... & 3,900 & 43.9 & 3,910 & 45.4 \\
\hline Savings institution .... & 946 & 10.6 & 929 & 10.8 \\
\hline Credit union ........ & 2,036 & 22.9 & 2,019 & 23.4 \\
\hline All $\ldots . . .$. & 6,882 & 77.4 & 6,858 & 79.7 \\
\hline Mortgage company & & & & \\
\hline Independent $\ldots \ldots \ldots$ & 1,328 & 14.9 & 1,124 & 13.1 \\
\hline Affiliated $^{1} \ldots \ldots \ldots \ldots$ & 676 & 7.6 & 628 & 7.3 \\
\hline All ..... & 2,004 & 22.6 & 1,752 & 20.3 \\
\hline All institutions . & 8,886 & 100 & 8,610 & 100 \\
\hline
\end{tabular}

1. Subsidiary of a depository institution or an affiliate of a bank holding company. 
application records included in the 2006 HMDA data. (The effects of such nonreporting on the 2007 data are discussed in more detail later in the article.)

\section{Disposition of Applications, Loan Types, and Activities Related to the Home Ownership and Equity Protection Act}

For purposes of analysis, loan applications and loans reported under HMDA can be grouped in many ways; here the analysis focuses on 25 distinct product categories characterized by loan and property type, purpose of the loan, and lien and owner-occupancy status. Each product category contains information on the number of total and pre-approval applications, application denials, originated loans, loans with prices above the reporting thresholds established by Regulation $\mathrm{C}$ for identifying higher-priced loans, loans covered by the Home Ownership and Equity Protection Act (HOEPA), and the mean and median annual percentage rate (APR) spreads for loans priced above the reporting thresholds specified in Regulation $\mathrm{C}$ (tables 3 and 4). ${ }^{13}$ The following sections highlight some notable aspects of the HMDA data for 2007 and, where relevant, earlier years.

\section{Conventional and Government-Backed Loans}

As in earlier years, most reported home loan activity in 2007 involved conventional loans-that is, nongovernment-backed loans (table 3). Such loans accounted for about 94 percent of all loan extensions in 2007.

The share of all HMDA-reported loans backed by the Federal Housing Administration (FHA) had fallen over the past several years, from about 16 percent in 2000 to less than 3 percent in 2005 and 2006. More-limited product availability and the imposition of tighter underwriting standards in the higher-priced segment of the conventional mortgage market in 2007 encouraged borrowers to take out FHA loans. Also, toward the latter part of 2007, the FHA created a new lending program, FHASecure, to help qualified individuals with higher-priced conventional loans refi-

13. HOEPA is implemented by Federal Reserve Board Regulation Z (12 C.F.R. pt. 226). Transition rules governing the reporting of the expanded HMDA data create problems for assessing the data on loan pricing, manufactured-home lending, and pre-approvals. The transition rules had a large influence on the data reported for 2004 and much smaller effects on the 2005 and 2006 data. In the 2007 data, transition rules affected only about 2,100 applications and 192 loans; the analyses here exclude those applications and loans when considering data on loan pricing, manufactured-home lending, and preapprovals. nance into an FHA loan. ${ }^{14}$ The number of FHAbacked first-lien loans used to purchase homes or refinance a home loan increased nearly 20 percent from 2006, and the FHA's share of all home lending increased to 4.6 percent in 2007 (data not shown in tables). ${ }^{15}$ The sharp curtailment of credit availability in the subprime portion of the market, recent steps to increase the maximum loan values that are eligible for FHA loan insurance, and a newly enacted foreclosure prevention law are likely to result in a higher incidence of FHA-insured lending in 2008. ${ }^{16}$

\section{Loan Size and Borrower Incomes}

For each loan made, the HMDA data include the amount borrowed and the incomes of the borrowers that were relied on in the loan underwriting decision. The analysis in this section considers four loan categories: (1) conventional loans that met the threshold for reporting as higher-priced loans under HMDA, (2) all other conventional loans, (3) FHA-insured loans, and (4) loans guaranteed by the Department of Veterans Affairs. The analysis is limited to site-built, owner-occupied, one- to four-family units, and the four categories are applied separately to homepurchase loans and to refinancings.

For 2007, about 91 percent of conventional loans for home purchase and about the same proportion of such loans for refinancing, whether higher priced or not, were within the conforming loan-size limits established for Fannie Mae and Freddie Mac (table 5). ${ }^{17}$ Higher-priced loans tended to be somewhat smaller than others; for example, among conventional home-purchase loans, the mean size of higher-priced mortgages was $\$ 208,000$, compared with $\$ 248,000$ for others (table 5, memo item).

FHA-insured loans tend to be considerably smaller than conventional loans; the difference reflects the relatively low insurance limits of the FHA and the focus of the program on lower- and middle-income borrowers who tend to buy more modestly priced

14. See U.S. Department of Housing and Urban Development, Federal Housing Administration (2007), "Bush Administration to Help Nearly One-Quarter of a Million Homeowners Refinance, Keep Their Homes," press release, August 31, www.hud.gov/news/ release.cfm?content $=$ pr07-123.cfm.

15. In contrast, the number of reported first-lien home-purchase loans or refinancings that involved loans guaranteed by the Department of Veterans Affairs fell about 2 percent from 2006.

16. Housing and Economic Recovery Act of 2008, Pub. L. No. 110-289 (2008).

17. For 2007, the conforming loan-size limit was $\$ 417,000$ for a single-unit property, with limits 50 percent higher for properties in Alaska and Hawaii. Higher limits are also established for two-, three-, and four-unit properties; however, because the HMDA data do not distinguish among properties with fewer than five units, the analysis here uses the $\$ 417,000$ limit. 
homes. For 2007, the mean size of FHA-insured home-purchase loans was $\$ 142,000$.

Borrower incomes differ substantially by loan product and loan pricing (table 6). Most notably, the mean income of borrowers with conventional loans, regardless of loan pricing, was about 72 percent higher than that of borrowers with FHA-insured loans (data derived from memo items in table). Among those obtaining conventional home-purchase mortgages, the mean income of individuals meeting the conforming loan-size limit established for Fannie Mae and Freddie Mac was $\$ 83,600$, versus a mean income of $\$ 293,100$ for those exceeding the conforming loan-size limit. Again, among borrowers with conventional loans, those using higher-priced loans to purchase a home or to refinance had a mean income about 20 percent lower than that of borrowers not paying higher prices.

\section{Non-Owner-Occupant Lending}

Part of the strong performance of housing markets over the first half of this decade was due to the growth in sales of homes to investors or individuals purchasing second or vacation homes, units collectively described as "non-owner occupied." HMDA data help document the role of investors and second-home buyers in the housing market because the data indicate whether the subject property is intended as the borrower's principal dwelling - that is, as an owneroccupied unit. ${ }^{18}$

The share of non-owner-occupant lending among first-lien loans to purchase one- to four-family sitebuilt homes rose in every year between 1996, when it was 6.4 percent, and 2005, when it reached a high of 17.3 percent (table 7). For 2006, the share fell somewhat, to 16.5 percent, and in 2007 it declined further, to 14.9 percent. Falling non-owner-occupant lending likely reflected the reduced incentives for such borrowing as house prices weakened or fell in many parts of the country and as the imposition of tighter lending standards for borrowers in this market segment reduced access to credit.

\section{Piggyback Lending}

In recent years, so-called piggyback loans emerged as an important segment of the conventional mortgage

18. An investment property is a non-owner-occupied dwelling that is intended to be continuously rented. Some non-owner-occupied units - vacation homes and second homes - are for the primary use of the owner and thus would not be considered investment properties. The HMDA data do not, however, distinguish between these two types of non-owner-occupied dwellings. market, particularly regarding loans to purchase homes. In piggyback lending, borrowers simultaneously receive a first-lien mortgage and a junior-lien (piggyback) loan. The piggyback loan finances the portion of the purchase price not being financed by the first mortgage and sometimes any cash payment that might have been made; the junior-lien loan may amount to as much as 20 percent of the purchase price.

Piggyback loans are generally used to reduce the cost of financing a home purchase. Often, they are designed to have a first-lien loan that can be financed at a lower price than a single loan for the total amount borrowed, such that the gains from the reduced finance costs on the first-lien loan outweigh the higher finance costs on the junior-lien loan portion of the total borrowing. A prime example is the practice of structuring the first-lien loan to avoid paying for private mortgage insurance (PMI) (for more information about PMI, see appendix B). Many of these loan transactions are structured so that the first-lien loan is eligible for sale to Fannie Mae or Freddie Mac, both of which require PMI on first-lien loans for amounts that exceed 80 percent of the value of the property backing the loan. Another example is the structuring of the loan transaction so that the first-lien loan can be more readily securitized in the secondary market. This practice has been common in the secondary market for subprime loans. Yet another example arises when the total amount requested exceeds the loan-size limits for Fannie Mae and Freddie Mac, thereby requiring the borrower to pay the higher interest rate usually charged on jumbo loans. Keeping the size of the first-lien loan within the amount that conforms to the loan-size limits of Fannie Mae and Freddie Mac can possibly result in lower overall financing costs.

The HMDA data can be used to help document the extent of piggyback lending over time. However, because not all lenders submit HMDA data, some of the junior-lien loans that are reported may not have the corresponding first-lien loan reported, and some of the first-lien loans that are reported may not have the associated junior-lien loan reported. Also, some piggyback loans may be home equity lines of credit (HELOCs) rather than closedend loans. Under the provisions of Regulation C, lenders need not report HELOCs. Nonetheless, a loan-matching process can be undertaken to determine which reported junior-lien loans appear to be associated with a reported first-lien loan. A juniorlien loan was identified as a piggyback to a reported first-lien loan if both loans (1) were conventional 
3. Disposition of applications for home loans, and origination and pricing of loans, by type of home and type of loan, 2007

\begin{tabular}{|c|c|c|c|c|c|c|c|c|c|c|c|c|}
\hline \multirow{4}{*}{ Type of home and loan } & \multicolumn{4}{|c|}{ Applications } & \multicolumn{8}{|c|}{ Loans originated } \\
\hline & \multirow{3}{*}{$\begin{array}{l}\text { Number } \\
\text { submitted }\end{array}$} & \multirow{2}{*}{\multicolumn{3}{|c|}{ Acted upon by lender }} & \multirow{3}{*}{ Number } & \multicolumn{7}{|c|}{ Loans with APR spread above the threshold ${ }^{1}$} \\
\hline & & & & & & \multirow[b]{2}{*}{ Number } & \multirow[b]{2}{*}{ Percent } & \multicolumn{5}{|c|}{ Distribution, by percentage points of APR spread } \\
\hline & & Number & \begin{tabular}{|c|}
$\begin{array}{l}\text { Number } \\
\text { denied }\end{array}$ \\
\end{tabular} & $\begin{array}{l}\text { Percent } \\
\text { denied }\end{array}$ & & & & 3-3.99 & 4-4.99 & $5-6.99$ & $7-8.99$ & $\begin{array}{l}9 \text { or } \\
\text { more }\end{array}$ \\
\hline \multirow{2}{*}{\multicolumn{13}{|c|}{$\begin{array}{c}\text { 1-4 FAMILY } \\
\text { NONBUSINESS RELATED }\end{array}$}} \\
\hline & & & & & & & & & & & & \\
\hline \multicolumn{10}{|l|}{$\begin{array}{l}\text { NONBUSINESS RELATED } \\
\text { Owner occupied }\end{array}$} & & & \\
\hline \multicolumn{13}{|l|}{ Site-built } \\
\hline \multicolumn{13}{|l|}{$\begin{array}{r}\text { Home purchase } \\
\text { Conventional }\end{array}$} \\
\hline First lien... & $4,654,084$ & $4,120,941$ & 783,972 & 19.0 & $2,928,820$ & 411,263 & 14.0 & 49.4 & 17.1 & 26.8 & 6.5 & 3 \\
\hline Junior lien .......... & 927,255 & 828,053 & 170,231 & 20.6 & 548,567 & 118,673 & 21.6 & & $\ldots$ & 65.8 & 30.0 & 4.3 \\
\hline \multicolumn{13}{|l|}{ Government backed } \\
\hline First lien ........... & 550,551 & 493,260 & 79,818 & 16.2 & 392,157 & 11,504 & 2.9 & 91.1 & 3.5 & 1.7 & 3.6 & .1 \\
\hline Junior lien & 1,348 & 1,138 & 85 & 7.5 & 1,008 & 65 & 6.4 & $\ldots$ & $\ldots$ & 76.9 & 18.5 & 4.6 \\
\hline \multicolumn{13}{|l|}{ Refinance } \\
\hline \multicolumn{13}{|l|}{ Conventional } \\
\hline First lien... & $8,550,904$ & $6,920,906$ & $2,758,715$ & 39.9 & $3,391,604$ & 735,150 & 21.7 & 39.1 & 19.6 & 33.8 & 7.4 & .1 \\
\hline \multirow{2}{*}{\multicolumn{13}{|c|}{ Government backed }} \\
\hline $\begin{array}{l}\text { Government backed } \\
\text { First lien .......... }\end{array}$ & 342,768 & & & 315 & & & & 92.1 & & & & \\
\hline Junior lien ......... & 710 & $\begin{array}{r}208,014 \\
527\end{array}$ & $\begin{array}{l}91,100 \\
151\end{array}$ & 28.7 & 316 & $\begin{array}{r}11,093 \\
63\end{array}$ & 19.9 & & & 65.1 & 31.7 & 3.2 \\
\hline \multirow{2}{*}{\multicolumn{13}{|c|}{ Home improvement }} \\
\hline Conventional & & & & & & & & & & & & \\
\hline First lien ... & 721,417 & 627,577 & 277,983 & 44.3 & 291,043 & 87,774 & 30.2 & 38.8 & 21.7 & 30.3 & 8.8 & .5 \\
\hline $\begin{array}{l}\text { Junior lien ........ } \\
\text { Government backed }\end{array}$ & 949,861 & 863,800 & 341,244 & 39.5 & 429,624 & 72,114 & 16.8 & & & 45.3 & 32.5 & 22.2 \\
\hline $\begin{array}{l}\text { Government backed } \\
\text { First lien }\end{array}$ & & & & & & & & & & & & \\
\hline $\begin{array}{l}\text { First lien .......... } \\
\text { Junior lien ........ }\end{array}$ & $\begin{array}{r}10,962 \\
3,407\end{array}$ & $\begin{array}{l}9,614 \\
2789\end{array}$ & 2,347 & 24.4 & 6,666 & $\begin{array}{r}410 \\
1044\end{array}$ & 6.2 & 59.5 & 7.6 & $\begin{array}{l}22.7 \\
398\end{array}$ & $\begin{array}{r}8.0 \\
316\end{array}$ & $\begin{array}{r}2.2 \\
28.5\end{array}$ \\
\hline Unsecured & & & & & & & & & & & & \\
\hline $\begin{array}{l}\text { or government } \\
\text { backed) } \ldots \ldots\end{array}$ & 347,359 & 340,661 & 167,456 & 49.2 & 146,395 & $\ldots$ & $\ldots$ & $\ldots$ & $\ldots$ & $\ldots$ & $\ldots$ & $\ldots$ \\
\hline Manufactured & & & & & & & & & & & & \\
\hline Conventional, first lien & & & & & & & & & & & & \\
\hline Home purchase ..... & 359,351 & 347,819 & 175,312 & 50.4 & 94,247 & 57,954 & 61.5 & 25.8 & 23.9 & 31.0 & 13.5 & 5.8 \\
\hline Refinance........ & 146,597 & 132,750 & 64,384 & 48.5 & 55,069 & 30,880 & 56.1 & 29.1 & 26.2 & 32.9 & 9.8 & 2.0 \\
\hline Other............... & 141,807 & 127,179 & 48,899 & 38.4 & 69,077 & 16,142 & 23.4 & 36.0 & 12.2 & 24.8 & 16.5 & 10.4 \\
\hline Non-owner occupied ${ }^{4}$ & & & & & & & & & & & & \\
\hline Conventional, first lien & & & & & & & & & & & & \\
\hline Home purchase ..... & 908,416 & 813,364 & 167,875 & 20.6 & 564,719 & 112,711 & 20.0 & 59.4 & 20.0 & 15.6 & 4.5 & .5 \\
\hline Refinance........ & 927,485 & 799,914 & 269,634 & 33.7 & 447,071 & 79,204 & 17.7 & 52.8 & 18.5 & 21.8 & 6.5 & $\begin{array}{llll}.4 & & & \end{array}$ \\
\hline Other......... & 275,273 & 244,145 & 87,984 & 36.0 & 129,959 & 31,731 & 24.4 & 15.5 & 7.3 & 45.0 & 21.6 & 10.6 \\
\hline BusinESS RELATED ${ }^{3}$ & & & & & & & & & & & & \\
\hline Conventional, first lien & 19798 & 17626 & 1983 & 113 & 14863 & 881 & 59 & 605 & 145 & 237 & 10 & 2 \\
\hline $\begin{array}{l}\text { Home purchase ...... } \\
\text { Refinance.......... }\end{array}$ & $\begin{array}{l}19,98 \\
27,267\end{array}$ & $\begin{array}{l}17,020 \\
24,630\end{array}$ & 2,977 & $\begin{array}{l}11.3 \\
12.1\end{array}$ & $\begin{array}{l}14,803 \\
20,707\end{array}$ & $\begin{array}{r}881 \\
1,112\end{array}$ & 5.4 & $\begin{array}{l}00.5 \\
600\end{array}$ & $\begin{array}{l}14.9 \\
165\end{array}$ & 202 & 2.0 & .2 \\
\hline $\begin{array}{l}\text { Refinance........... } \\
\text { Other................ }\end{array}$ & 7,156 & $\begin{array}{r}24,030 \\
6,867\end{array}$ & 1,074 & 15.6 & 5,463 & 149 & 2.7 & 28.9 & 11.4 & 45.0 & 12.1 & 2.7 \\
\hline MULTIFAMILY 5 & & & & & & & & & & & & \\
\hline Conventional, first lien & & & & & & & & & & & & \\
\hline Home purchase ..... & 48,635 & 46,057 & 1,991 & 4.3 & 43,063 & 2,904 & 6.7 & 44.7 & 23.0 & 11.6 & 15.1 & 5.6 \\
\hline Refinance. . & 43,127 & 37,951 & 4,333 & 11.4 & 32,401 & 2,808 & 8.7 & 51.1 & 27.9 & 13.2 & 7.5 & .3 \\
\hline Other ......... & 15,488 & 13,356 & 1,728 & 12.9 & 11,164 & 491 & 4.4 & 34.6 & 13.4 & 31.6 & 13.8 & 6.5 \\
\hline Total & $21,389,258$ & $18,337,983$ & $5,952,496$ & 32.5 & $10,441,353$ & $1,907,774$ & 18.3 & 36.4 & 15.7 & 34.1 & 11.5 & 2.4 \\
\hline
\end{tabular}

Note: Excludes transition-period applications (those submitted before 2004) and transition-period loans (those for which the application was submitted before 2004).

1. Annual percentage rate (APR) spread is the difference between the APR on the loan and the yield on a comparable-maturity Treasury security. The threshold for first-lien loans is a spread of 3 percentage points; for junior-lien loans, it is a spread of 5 percentage points.

2. Loans covered by the Home Ownership and Equity Protection Act of 1994 (HOEPA), which does not apply to home-purchase loans.

loans involving property in the same census tract, (2) were originated by the same lender with approximately the same dates of loan application and clos-
3. Business-related applications and loans are those for which the lender reported that the race, ethnicity, and sex of the applicant or co-applicant are "not applicable"; all other applications and loans are nonbusiness related.

4. Includes applications and loans for which occupancy status was missing.

5. Includes business-related and nonbusiness-related applications and loans for owner-occupied and non-owner-occupied properties.

... Not applicable.

ing, and (3) had the same owner-occupancy status and identical borrower income, race or ethnicity, and sex. 
3. Disposition of applications for home loans, and origination and pricing of loans, by type of home and type of loan, 2007-Continued

\begin{tabular}{|c|c|c|c|c|c|c|c|c|}
\hline \multirow{2}{*}{\multicolumn{3}{|c|}{$\begin{array}{l}\text { Loans originated } \\
\text { Loans with APR spread above the threshold }{ }^{1}\end{array}$}} & \multirow{2}{*}{\multicolumn{6}{|c|}{$\begin{array}{l}\text { MEMO } \\
\text { Transition-period applications (those submitted before 2004) }\end{array}$}} \\
\hline & & & & & & & & \\
\hline \multicolumn{2}{|c|}{ APR spread (percentage points) } & \multirow{2}{*}{$\begin{array}{c}\text { Number of } \\
\text { HOEPA- } \\
\text { covered } \\
\text { loans }{ }^{2}\end{array}$} & \multirow[b]{2}{*}{$\begin{array}{l}\text { Number } \\
\text { submitted }\end{array}$} & \multirow[b]{2}{*}{$\begin{array}{c}\text { Number } \\
\text { denied }\end{array}$} & \multirow[b]{2}{*}{$\begin{array}{l}\text { Percent } \\
\text { denied }\end{array}$} & \multicolumn{2}{|c|}{ Loans originated } & \multirow{2}{*}{$\begin{array}{c}\text { Number o } \\
\text { HOEPA- } \\
\text { covered } \\
\text { loans }^{2}\end{array}$} \\
\hline Mean & Median & & & & & Number & $\begin{array}{c}\text { Percent with } \\
\text { APR spread } \\
\text { above threshold }\end{array}$ & \\
\hline $\begin{array}{l}4.5 \\
6.6\end{array}$ & $\begin{array}{l}4.0 \\
6.3\end{array}$ & & $\begin{array}{r}305 \\
19\end{array}$ & $\begin{array}{r}10 \\
1\end{array}$ & $\begin{array}{l}5.9 \\
9.1\end{array}$ & $\begin{array}{r}67 \\
6\end{array}$ & $\begin{array}{l}6.0 \\
0\end{array}$ & $\begin{array}{l}\ldots \\
\cdots\end{array}$ \\
\hline $\begin{array}{l}3.5 \\
6.7\end{array}$ & $\begin{array}{l}3.2 \\
6.4\end{array}$ & $\ldots$ & $\begin{array}{r}26 \\
0\end{array}$ & $\begin{array}{l}0 \\
0\end{array}$ & $\begin{array}{l}0 \\
0\end{array}$ & $\begin{array}{r}12 \\
0\end{array}$ & $\begin{array}{c}50.0 \\
0\end{array}$ & $\ldots$ \\
\hline $\begin{array}{l}4.8 \\
6.9\end{array}$ & $\begin{array}{l}4.5 \\
6.6\end{array}$ & $\begin{array}{l}3,145 \\
1,951\end{array}$ & $\begin{array}{r}1,488 \\
36\end{array}$ & $\begin{array}{r}17 \\
1\end{array}$ & $\begin{array}{l}1.6 \\
4.2\end{array}$ & $\begin{array}{r}30 \\
4\end{array}$ & $\begin{array}{l}20.0 \\
25.0\end{array}$ & $\begin{array}{l}0 \\
0\end{array}$ \\
\hline $\begin{array}{l}3.4 \\
6.7\end{array}$ & $\begin{array}{l}3.2 \\
6.4\end{array}$ & $\begin{array}{r}120 \\
0\end{array}$ & $\begin{array}{r}16 \\
1\end{array}$ & $\begin{array}{l}2 \\
0\end{array}$ & $\begin{array}{c}22.2 \\
0\end{array}$ & $\begin{array}{l}4 \\
0\end{array}$ & $\begin{array}{c}25.0 \\
0\end{array}$ & $\begin{array}{l}0 \\
0\end{array}$ \\
\hline 4.8 & 4.5 & 1,214 & 3 & 0 & 0 & 2 & 0 & 0 \\
\hline 7.5 & 7.3 & 2,827 & 1 & 0 & 0 & 0 & 0 & 0 \\
\hline \multirow{3}{*}{$\begin{array}{l}4.5 \\
7.5\end{array}$} & 3.6 & 6 & 0 & 0 & 0 & 0 & 0 & 0 \\
\hline & 7.4 & 6 & 0 & 0 & 0 & 0 & 0 & 0 \\
\hline & $\ldots$ & $\ldots$ & 0 & 0 & 0 & 0 & 0 & $\ldots$ \\
\hline 5.5 & 5.0 & & 4 & 0 & 0 & 1 & 0 & \\
\hline 5.1 & 4.8 & 1,184 & 9 & 0 & 0 & 1 & 0 & 0 \\
\hline 5.6 & 5.1 & 810 & 4 & 0 & 0 & 1 & 0 & 0 \\
\hline 4.2 & 3.8 & & 50 & 0 & 0 & 11 & 0 & \\
\hline 4.4 & 3.9 & 156 & 94 & 3 & 5.0 & 9 & 33.3 & $\ddot{0}$ \\
\hline 6.2 & 5.9 & 73 & 6 & 0 & 0 & 4 & 50.0 & 0 \\
\hline 4.2 & 3.7 & & 5 & 0 & 0 & 5 & 0 & \\
\hline 4.3 & 3.8 & 3 & 5 & 0 & 0 & 5 & 0 & 0 \\
\hline 5.3 & 5.2 & 1 & 1 & 0 & 0 & 1 & 0 & 0 \\
\hline 5.0 & 4.2 & & 32 & 0 & 0 & 25 & 16.0 & \\
\hline 4.4 & 4.0 & 6 & 1 & 0 & 0 & 1 & 0 & 0 \\
\hline 5.5 & 5.1 & 2 & 9 & 0 & 0 & 3 & 0 & 0 \\
\hline 5.1 & 4.8 & 11,504 & 2,115 & 34 & 2.3 & 192 & 14.1 & 0 \\
\hline
\end{tabular}

Extent of piggyback lending. The HMDA data show that lenders extended a substantial number of juniorlien loans to help individuals purchase homes (for both owner-occupied and non-owner-occupied purposes) in 2005 and 2006 but that such lending contracted sharply in 2007.19 For 2005, lenders

19. A similar matching process was used to identify piggyback loans used for refinancing. HMDA reporting requirements, however, are less comprehensive for refinance loans, and therefore junior-lien loans used for refinancing are less likely to be reported. As a result, we do not report data on piggyback loan transactions used for refinancing. reported on about 1.37 million junior-lien loans used to purchase homes; for 2006, they reported on about 1.43 million (data not shown in tables). In 2007, lenders covered by HMDA reported information on only about 600,000 junior-lien loans to purchase homes, a decline of nearly 60 percent from the 2006 level.

Regarding piggyback lending, our matching algorithm indicates that about 12 percent of the 2.9 million 2007 first-lien home-purchase loans on owneroccupied site-built homes for one to four families 
4. Home-purchase lending that began with a request for pre-approval: Disposition and pricing, by type of home, 2007

\begin{tabular}{|c|c|c|c|c|c|c|}
\hline \multirow{3}{*}{ Type of home } & \multicolumn{3}{|c|}{ Requests for pre-approval } & \multicolumn{3}{|c|}{ Applications preceded by requests for pre-approval ${ }^{1}$} \\
\hline & \multirow[b]{2}{*}{$\begin{array}{l}\text { Number acted } \\
\text { upon by lender }\end{array}$} & \multirow[b]{2}{*}{$\begin{array}{l}\text { Number } \\
\text { denied }\end{array}$} & \multirow[b]{2}{*}{$\begin{array}{l}\text { Percent } \\
\text { denied }\end{array}$} & \multirow[b]{2}{*}{$\begin{array}{l}\text { Number } \\
\text { submitted }\end{array}$} & \multicolumn{2}{|c|}{ Acted upon by lender } \\
\hline & & & & & Number & Number denied \\
\hline \multirow{2}{*}{\multicolumn{7}{|c|}{$\begin{array}{c}\text { 1-4 FAMILY } \\
\text { NoNBUSINESS RELATED }\end{array}$}} \\
\hline \multirow{2}{*}{\multicolumn{7}{|c|}{$\begin{array}{l}\text { NONBUSINESS RELATED } \\
\text { Owner occupied }\end{array}$}} \\
\hline & & & & & & Site-built \\
\hline \multicolumn{7}{|l|}{ Conventional } \\
\hline First lien .. & 754,318 & 209,478 & 27.8 & 420,435 & 371,847 & 37,300 \\
\hline Junior lien .......... & 95,782 & 28,538 & 29.8 & 54,088 & 48,760 & 5,585 \\
\hline \multicolumn{7}{|l|}{ Government backed } \\
\hline First lien..$\ldots \ldots$ & 85,606 & 31,821 & 37.2 & 55,236 & 48,944 & 5,524 \\
\hline Junior lien . . . . . . . . . . . . & 95 & 13 & 13.7 & 84 & 72 & 4 \\
\hline \multicolumn{7}{|l|}{ Manufactured } \\
\hline Conventional, first lien ........... & 45,358 & 22,802 & 50.3 & 42,728 & 37,831 & 20,624 \\
\hline Other $\ldots \ldots \ldots \ldots \ldots \ldots \ldots \ldots \ldots$ & 6,418 & 2,361 & 36.8 & 4,918 & 3,632 & 1,094 \\
\hline \multicolumn{7}{|l|}{ Non-owner occupied ${ }^{4}$} \\
\hline Conventional, first lien & 69,916 & 16,237 & 23.2 & 48,688 & 42,576 & 6,639 \\
\hline Other $\ldots \ldots \ldots \ldots \ldots \ldots \ldots$ & 6,040 & 1,850 & 30.6 & 4,637 & 4,020 & 1,032 \\
\hline \multirow{2}{*}{\multicolumn{7}{|c|}{$\begin{array}{l}\text { BuSINESS RELATED }^{3} \\
\text { Conventional, first lien ...... }\end{array}$}} \\
\hline & 1,169 & 131 & 11.2 & 1,126 & 943 & 102 \\
\hline Other $\ldots \ldots \ldots \ldots \ldots \ldots \ldots$ & 209 & 19 & 9.1 & 202 & 161 & 12 \\
\hline \\
\hline Conventional, first lien $\ldots \ldots \ldots \ldots \ldots$ & 321 & 109 & 34.0 & 220 & 164 & 23 \\
\hline Other $\ldots \ldots \ldots \ldots \ldots \ldots \ldots \ldots \ldots \ldots \ldots$ & 35 & 1 & 2.9 & 34 & 22 & 1 \\
\hline Total & $1,065,267$ & 313,360 & 29.4 & 632,396 & $\mathbf{5 5 8 , 9 7 2}$ & 77,940 \\
\hline \multicolumn{3}{|c|}{$\begin{array}{l}\text { NOTE: Excludes transition-period requests for pre-approval (those submitted } \\
\text { before 2004). See general note to table } 1 \text {. } \\
\text { 1. These applications are included in the total of } 21,389,258 \text { reported in } \\
\text { table } 3 \text {. }\end{array}$} & \multicolumn{3}{|c|}{$\begin{array}{l}\text { 4. Includes applications and loans for which occupancy status was missing. } \\
\text { 5. Includes business-related and nonbusiness-related applications and loans } \\
\text { for owner-occupied and non-owner-occupied properties. } \\
\text {. . Not applicable. }\end{array}$} & $\begin{array}{l}\text { status was missing. } \\
\text { lications and loans }\end{array}$ \\
\hline
\end{tabular}

involved a piggyback loan reported by the same lender, a proportion that was down 45 percent from 2006 (data not shown in tables).

Changing nature of piggyback lending. A comparison of the 2007 HMDA data with the HMDA data for earlier years suggests that the nature of piggyback lending has changed. The HMDA data for 2005, 2006, and 2007 can be used to distinguish three types of piggyback loan arrangements: (1) those likely to be used as substitutes for PMI, (2) those intended primarily to keep the size of the first-lien loan within the limits set for loans that Fannie Mae and Freddie Mac are allowed to purchase in a given year, and (3) those used for other purposes, most likely to facilitate sale of the loan to the secondary market.

For purposes of this analysis, piggyback loans were assumed to be in the first category if two conditions were satisfied: (1) The first-lien loan in a piggyback loan transaction was not higher priced, and (2) the combined loan amount of the first- and junior-lien loans was less than the conforming loan-size limit. Piggyback loans were assumed to be in the second category if three conditions were satisfied: (1) The first-lien loan in a piggyback loan transaction was not higher priced, (2) the amount of the first-lien loan was under the conforming loan-size limit, and (3) the combined loan amount of the first- and junior-lien loans exceeded the conforming loan-size limit. For the first two categories of piggyback loans, the presumption is that the piggyback loan was used to facilitate sales to Fannie Mae or Freddie Mac. Consequently, in the analysis, we distinguish between loans that have been sold to Fannie Mae and Freddie Mac and those that might be sold. The third category of piggyback loans consists of those that do not appear eligible to be sold to these two entities because the first-lien loan is higher-priced or the loan amount exceeds the conforming loan-size limit. ${ }^{20}$

The analysis indicates that the share of piggyback loans used to keep the first-lien loan within the

20. Higher-priced loans are generally not eligible for purchase by Fannie Mae or Freddie Mac. Such loans typically involve elevated credit risk or have other features that tend to make them ineligible for purchase by these institutions. 
4. Home-purchase lending that began with a request for pre-approval: Disposition and pricing, by type of home, 2007—Continued

\begin{tabular}{|c|c|c|c|c|c|c|c|c|c|c|c|c|c|c|}
\hline \multicolumn{10}{|c|}{ Loan originations whose applications were preceded by requests for pre-approval } & \multirow{2}{*}{\multicolumn{5}{|c|}{$\begin{array}{l}\text { MЕмо } \\
\text { Applications with transition-period requests for pre- } \\
\text { approval (request submitted before 2004) }\end{array}$}} \\
\hline \multirow[b]{3}{*}{ Number } & \multicolumn{9}{|c|}{ Loans with APR spread above the threshold ${ }^{2}$} & & & & & \\
\hline & \multirow[b]{2}{*}{ Number } & \multirow[b]{2}{*}{ Percent } & \multicolumn{5}{|c|}{ Distribution, by percentage points of APR spread } & \multicolumn{2}{|c|}{$\begin{array}{c}\text { APR spread } \\
\text { (percentage points) }\end{array}$} & \multirow[b]{2}{*}{$\begin{array}{c}\text { Number } \\
\text { submitted }\end{array}$} & \multirow[b]{2}{*}{$\begin{array}{c}\text { Number } \\
\text { denied }\end{array}$} & \multirow[b]{2}{*}{$\begin{array}{l}\text { Percent } \\
\text { denied }\end{array}$} & \multicolumn{2}{|c|}{ Loans originated } \\
\hline & & & $3-3.99$ & $4-4.99$ & $5-6.99$ & $7-8.99$ & $\begin{array}{l}9 \text { or } \\
\text { more }\end{array}$ & $\begin{array}{l}\text { Mean } \\
\text { spread }\end{array}$ & $\begin{array}{l}\text { Median } \\
\text { spread }\end{array}$ & & & & Number & $\begin{array}{c}\text { Percent } \\
\text { with APR } \\
\text { spread } \\
\text { above } \\
\text { threshold }\end{array}$ \\
\hline 302,513 & 19,003 & 6.3 & 65.5 & 18.6 & 12.9 & 2.5 & .4 & 4.0 & 3.6 & 7 & 0 & 0 & 2 & 0 \\
\hline 35,759 & 3,609 & 10.1 & $\ldots$ & $\ldots$ & 71.9 & 21.9 & 6.2 & 6.4 & 5.9 & 3 & 0 & 0 & 2 & 0 \\
\hline 41,437 & 1,357 & 3.3 & 74.3 & 9.7 & 3.5 & 12.5 & 0 & 4.0 & 3.4 & 8 & 0 & 0 & 7 & 85.7 \\
\hline & & 1.6 & $\ldots$ & $\ldots$ & 100 & 0 & 0 & 5.3 & 5.3 & 0 & 0 & 0 & 0 & 0 \\
\hline 9,754 & 6,999 & 71.8 & 14.3 & 23.2 & 45.2 & 15.1 & 2.1 & 5.6 & 5.5 & 0 & 0 & 0 & 0 & 0 \\
\hline 2,425 & 331 & 13.6 & 73.7 & .3 & 6.0 & 19.9 & 0 & 4.3 & 3.3 & 0 & 0 & 0 & 0 & 0 \\
\hline 31,846 & 3,856 & 12.1 & 60.6 & 20.4 & 14.7 & 3.7 & .5 & 4.2 & 3.7 & 1 & 0 & 0 & 1 & 0 \\
\hline 2,209 & 405 & 18.3 & .2 & 0 & 52.6 & 32.3 & 14.8 & 7.1 & 6.8 & 0 & 0 & 0 & 0 & 0 \\
\hline 803 & 53 & 6.6 & 58.5 & 17.0 & 15.1 & 9.4 & 0 & 4.4 & 3.8 & 1 & 0 & 0 & 0 & 0 \\
\hline 140 & 12 & 8.6 & 33.3 & 0 & 33.3 & 25.0 & 8.3 & 5.9 & 5.8 & 0 & 0 & 0 & 0 & 0 \\
\hline 125 & 13 & 10.4 & 76.9 & 7.7 & 7.7 & 7.7 & 0 & 3.9 & 3.2 & 0 & 0 & 0 & 0 & 0 \\
\hline 20 & 2 & 10.0 & 0 & 0 & 100 & 0 & 0 & 6.0 & 6.0 & 0 & 0 & 0 & 0 & 0 \\
\hline 427,095 & 35,641 & 8.3 & 48.0 & 17.1 & 25.4 & 8.0 & 1.5 & 4.6 & 4.1 & 20 & 0 & 0 & 12 & 50.0 \\
\hline
\end{tabular}

5. Cumulative distribution of home loans, by loan amount and by purpose, type, and pricing of loan, 2007

Percent

\begin{tabular}{|c|c|c|c|c|c|c|c|c|c|c|}
\hline \multirow{3}{*}{$\begin{array}{c}\text { Upper bound } \\
\text { of loan amount } \\
\text { (thousands of } \\
\text { dollars) })^{1}\end{array}$} & \multicolumn{5}{|c|}{ Home purchase } & \multicolumn{5}{|c|}{ Refinance } \\
\hline & \multicolumn{3}{|c|}{ Conventional } & \multirow[b]{2}{*}{ FHA } & \multirow[b]{2}{*}{ VA } & \multicolumn{3}{|c|}{ Conventional } & \multirow[b]{2}{*}{ FHA } & \multirow[b]{2}{*}{ VA } \\
\hline & $\begin{array}{l}\text { Lower } \\
\text { priced }\end{array}$ & $\begin{array}{l}\text { Higher } \\
\text { priced }\end{array}$ & Total & & & $\begin{array}{l}\text { Lower } \\
\text { priced }\end{array}$ & $\begin{array}{l}\text { Higher } \\
\text { priced }\end{array}$ & Total & & \\
\hline 24 & .2 & 1.0 & .3 & .1 & .0 & .7 & 2.3 & 1.1 & .1 & .1 \\
\hline 49 & 1.8 & 5.5 & 2.3 & 2.2 & .4 & 3.3 & 7.1 & 4.1 & 1.0 & .9 \\
\hline 74 & 6.3 & 15.5 & 7.6 & 11.3 & 2.5 & 8.9 & 16.1 & 10.5 & 6.0 & 4.7 \\
\hline 99. & 13.3 & 26.4 & 15.1 & 26.6 & 8.8 & 16.4 & 26.2 & 18.5 & 17.3 & 13.5 \\
\hline 124 & 23.2 & 37.0 & 25.2 & 42.6 & 18.5 & 25.7 & 37.2 & 28.2 & 32.7 & 25.2 \\
\hline 149 & 33.5 & 47.3 & 35.5 & 60.6 & 32.9 & 34.5 & 47.0 & 37.2 & 50.2 & 40.1 \\
\hline 174 & 43.2 & 55.6 & 45.0 & 75.0 & 47.8 & 43.5 & 55.8 & 46.2 & 65.1 & 53.0 \\
\hline 199 & 51.4 & 62.3 & 53.0 & 85.1 & 60.6 & 51.1 & 62.8 & 53.7 & 76.5 & 64.5 \\
\hline 224 & 59.1 & 68.2 & 60.4 & 90.9 & 70.4 & 58.5 & 69.0 & 60.8 & 84.8 & 74.3 \\
\hline 249 & 65.0 & 73.1 & 66.1 & 94.2 & 78.9 & 64.2 & 73.9 & 66.3 & 89.8 & 81.7 \\
\hline 274 & 70.2 & 77.2 & 71.2 & 96.3 & 85.0 & 69.6 & 77.9 & 71.4 & 93.4 & 87.5 \\
\hline 299 & 74.3 & 80.5 & 75.2 & 97.7 & 89.3 & 73.7 & 81.2 & 75.3 & 95.7 & 91.0 \\
\hline 324 & 78.3 & 83.4 & 79.0 & 98.5 & 92.5 & 77.9 & 84.1 & 79.2 & 97.3 & 93.9 \\
\hline 349 & 81.3 & 85.7 & 81.9 & 99.1 & 94.9 & 80.9 & 86.4 & 82.1 & 98.4 & 95.8 \\
\hline 374 & 84.0 & 87.9 & 84.5 & 99.7 & 96.7 & 83.8 & 88.5 & 84.8 & 99.6 & 97.5 \\
\hline 399 & 86.2 & 89.8 & 86.7 & 99.7 & 98.0 & 86.1 & 90.1 & 87.0 & 99.7 & 98.6 \\
\hline 417 & 90.5 & 91.4 & 90.6 & 99.8 & 99.5 & 90.3 & 91.5 & 90.5 & 99.7 & 99.6 \\
\hline 449 & 91.2 & 92.7 & 91.4 & 99.9 & 99.6 & 91.2 & 92.9 & 91.6 & 99.8 & 99.8 \\
\hline 499 & 92.7 & 94.6 & 93.0 & 99.9 & 99.8 & 92.9 & 94.9 & 93.3 & 99.9 & 99.9 \\
\hline 549 & 94.2 & 96.1 & 94.5 & 100 & 99.9 & 94.5 & 96.3 & 94.9 & 100 & 99.9 \\
\hline 599 & 95.2 & 97.0 & 95.5 & 100 & 99.9 & 95.5 & 97.2 & 95.9 & 100 & 100 \\
\hline 649 & 96.2 & 97.8 & 96.4 & 100 & 100 & 96.5 & 97.9 & 96.8 & 100 & 100 \\
\hline 699 & 96.8 & 98.3 & 97.0 & 100 & 100 & 97.2 & 98.4 & 97.4 & 100 & 100 \\
\hline 749 & 97.3 & 98.6 & 97.5 & 100 & 100 & 97.6 & 98.7 & 97.8 & 100 & 100 \\
\hline $799 \ldots \ldots \ldots$ & 97.7 & 98.8 & 97.9 & 100 & 100 & 98.0 & 98.9 & 98.2 & 100 & 100 \\
\hline More than 799 . & 100 & 100 & 100 & 100 & 100 & 100 & 100 & 100 & 100 & 100 \\
\hline \multicolumn{11}{|l|}{$\begin{array}{l}\text { MEMO } \\
\text { Loan amount } \\
\text { (thousands } \\
\text { of dollars) }\end{array}$} \\
\hline Mean $\ldots . .$. & 247.9 & 207.9 & 242.3 & 142.3 & 193.1 & 243.9 & 203.2 & 235.0 & 160.3 & 181.7 \\
\hline Median $^{1}$ & 194 & 157 & 189 & 134 & 179 & 195 & 157 & 186 & 149 & 168 \\
\hline
\end{tabular}

NoTE: For definitions of lower- and higher-priced lending, see text note $7 . \quad$ FHA Federal Housing Administration.

1. Loan amounts are reported under the Home Mortgage Disclosure Act to VA Department of Veterans Affairs.

the nearest $\$ 1,000$. 
6. Cumulative distribution of home loans, by borrower income and by purpose, type, and pricing of loan, 2007 Percent

\begin{tabular}{|c|c|c|c|c|c|c|c|c|c|c|}
\hline \multirow{3}{*}{$\begin{array}{l}\text { Upper bound of } \\
\text { borrower income } \\
\text { (thousands of }^{\text {dollars) }}\end{array}$} & \multicolumn{5}{|c|}{ Home purchase } & \multicolumn{5}{|c|}{ Refinance } \\
\hline & \multicolumn{3}{|c|}{ Conventional } & \multirow[b]{2}{*}{ FHA } & \multirow[b]{2}{*}{ VA } & \multicolumn{3}{|c|}{ Conventional } & \multirow[b]{2}{*}{ FHA } & \multirow[b]{2}{*}{ VA } \\
\hline & $\begin{array}{l}\text { Lower } \\
\text { priced }\end{array}$ & $\begin{array}{l}\text { Higher } \\
\text { priced }\end{array}$ & Total & & & $\begin{array}{l}\text { Lower } \\
\text { priced }\end{array}$ & $\begin{array}{l}\text { Higher } \\
\text { priced }\end{array}$ & Total & & \\
\hline 24 & 2.4 & 5.3 & 2.8 & 4.6 & .7 & 2.7 & 5.1 & 3.2 & 2.9 & 3.6 \\
\hline 49 & 24.2 & 35.1 & 25.7 & 43.5 & 28.2 & 22.6 & 33.6 & 25.0 & 34.2 & 29.4 \\
\hline 74 & 48.2 & 61.0 & 49.9 & 78.1 & 66.3 & 48.2 & 61.9 & 51.2 & 72.2 & 65.8 \\
\hline 99 . & 65.9 & 76.6 & 67.4 & 92.4 & 87.5 & 67.4 & 78.9 & 69.9 & 91.1 & 86.4 \\
\hline $124^{\circ}$ & 77.4 & 85.3 & 78.5 & 96.9 & 95.7 & 79.4 & 87.7 & 81.2 & 97.4 & 95.5 \\
\hline 149. & 84.1 & 90.0 & 84.9 & 98.4 & 98.5 & 85.9 & 92.0 & 87.3 & 99.0 & 98.5 \\
\hline & 91.5 & 94.9 & 91.9 & 99.3 & 99.8 & 92.7 & 96.1 & 93.5 & 99.7 & 99.6 \\
\hline & 94.7 & 96.9 & 95.0 & 99.6 & 99.9 & 95.6 & 97.6 & 96.0 & 99.8 & 99.9 \\
\hline & 96.3 & 97.8 & 96.5 & 99.7 & 100 & 96.9 & 98.4 & 97.2 & 99.8 & 99.9 \\
\hline More than 299 & 100 & 100 & 100 & 100 & 100 & 100 & 100 & 100 & 100 & 100 \\
\hline \multicolumn{11}{|l|}{$\begin{array}{l}\text { Mемо } \\
\text { Borrower income, } \\
\text { by selected } \\
\text { loan type } \\
\text { (thousands } \\
\text { of dollars) }\end{array}$} \\
\hline All & \multirow{3}{*}{$\begin{array}{l}105.5 \\
77\end{array}$} & \multirow{3}{*}{$\begin{array}{l}85.5 \\
62\end{array}$} & \multirow{3}{*}{$\begin{array}{l}102.8 \\
75\end{array}$} & \multirow{3}{*}{$\begin{array}{l}59.8 \\
53\end{array}$} & \multirow{3}{*}{$\begin{array}{l}68.3 \\
62\end{array}$} & \multirow{3}{*}{$\begin{array}{l}101.3 \\
76\end{array}$} & \multirow{3}{*}{$\begin{array}{l}80.6 \\
63\end{array}$} & \multirow{3}{*}{$\begin{array}{l}96.8 \\
73\end{array}$} & \multirow{3}{*}{$\begin{array}{l}64.2 \\
59\end{array}$} & \\
\hline $\begin{array}{l}\text { Mean } \ldots \ldots . . . \\
\text { Median }^{1} \ldots\end{array}$ & & & & & & & & & & \multirow[t]{3}{*}{$\begin{array}{l}67.7 \\
63\end{array}$} \\
\hline $\begin{array}{l}\text { Below the conforming } \\
\text { loan size } 3^{3}\end{array}$ & & & & & & & & & & \\
\hline Mean ….......... & \multirow{3}{*}{$\begin{array}{l}85.7 \\
71\end{array}$} & \multirow{3}{*}{$\begin{array}{l}70.5 \\
59\end{array}$} & \multirow{3}{*}{$\begin{array}{l}83.6 \\
70\end{array}$} & \multirow{3}{*}{$\cdots$} & \multirow{3}{*}{$\cdots$} & \multirow{3}{*}{$\begin{array}{l}84.5 \\
72\end{array}$} & \multirow{3}{*}{$\begin{array}{l}68.2 \\
60\end{array}$} & \multirow{3}{*}{$\begin{array}{l}80.9 \\
69\end{array}$} & \multirow{3}{*}{$\cdots$} & \\
\hline Median $^{1}$. & & & & & & & & & & \multirow{2}{*}{$\cdots$} \\
\hline $\begin{array}{l}\text { Above the conforming } \\
\text { loan size }{ }^{4}\end{array}$ & & & & & & & & & & \\
\hline Mean $\ldots \ldots \ldots \ldots \ldots$ & 298.1 & 256.3 & 293.1 & $\ldots$ & $\ldots$ & 259.1 & 218.2 & 251.2 & $\ldots$ & $\ldots$ \\
\hline Median $^{1} \ldots \ldots \ldots$ & 210 & 181 & 205 & & $\ldots$ & 184 & 163 & 180 & $\ldots$ & \\
\hline
\end{tabular}

NOTE: For loans with two or more applicants, HMDA-covered lenders report data on only two. Income for two applicants is reported jointly. For definitions of lower- and higher-priced lending, see text note 7 .

1. Income amounts are reported under HMDA to the nearest $\$ 1,000$.

2. By size, all loans backed by the FHA or VA are conforming.

3. The conforming loan-size limit established for most loan purchases by Fannie Mae and Freddie Mac is $\$ 417,000$. For more information, see text note 17.

7. Non-owner-occupied lending as a share of all first liens to purchase one- to four-family site-built homes, by number and dollar amount of loans, 1990-2007

Percent

\begin{tabular}{|c|c|c|}
\hline Year & Number & Dollar amount \\
\hline 1990 . & 6.6 & 5.9 \\
\hline 1991. & 5.6 & 4.5 \\
\hline 1992. & 5.2 & 4.0 \\
\hline 1993. & 5.1 & 3.8 \\
\hline 1994. & 5.7 & 4.3 \\
\hline 1995. & 6.4 & 5.0 \\
\hline 1996. & 6.4 & 5.1 \\
\hline 1997. & 7.0 & 5.8 \\
\hline 1998 . & 7.1 & 6.0 \\
\hline 1999 . & 7.4 & 6.4 \\
\hline $2000 \ldots$ & 8.0 & 7.2 \\
\hline 2001 . & 8.6 & 7.6 \\
\hline 2002 . & 10.5 & 9.2 \\
\hline 2003. & 11.9 & 10.6 \\
\hline 2004 . & 14.9 & 13.1 \\
\hline 2005 . & 17.3 & 15.7 \\
\hline 2006 . & 16.5 & 14.8 \\
\hline 2007. & 14.9 & 13.8 \\
\hline
\end{tabular}

conforming loan-size limit increased in 2007 from 2006 and 2005. For example, the share of lower-
4. Loans above $\$ 417,000$, the conforming loan-size limit established for most loan purchases by Fannie Mae and Freddie Mac, are sometimes referred to as jumbo loans. For more information, see text notes 11 and 17.

... Not applicable.

FHA Federal Housing Administration.

VA Department of Veterans Affairs.

priced piggyback loans used to keep the first-lien loan within the conforming loan-size limits increased from 8.8 percent in 2006 to 12.3 percent in 2007 (data derived from table 8 ). The number of piggyback loans sold to Fannie Mae or Freddie Mac that were used to keep the first-lien loan within the conforming loansize limits also increased from 2006 to 2007-by some 63 percent-despite a sharp decline in the total number of piggyback loans over this period. These results suggest that in 2007 relatively more borrowers used their piggybacks to take advantage of the lower rates available on the first-lien portion of their piggyback arrangements than to obtain a needed source of down payment.

In contrast, the data suggest that the use of piggyback loans as a substitute for PMI declined in 2007 from 2006. This was true of the loans sold to Fannie Mae and Freddie Mac as well as those that potentially were eligible for sale. The use of piggyback loans for purposes that made the loans non-eligible for sale to Fannie Mae and Freddie Mac also declined significantly. The decrease was most precipitous for higher- 
8. Distribution of piggyback loan transactions involving home purchases, by status of first-lien loan, 2004-07

\begin{tabular}{|c|c|c|c|c|c|c|c|c|}
\hline \multirow{2}{*}{ Status of first-lien loan } & \multicolumn{2}{|c|}{2004} & \multicolumn{2}{|c|}{2005} & \multicolumn{2}{|c|}{2006} & \multicolumn{2}{|c|}{2007} \\
\hline & Number & Percent & Number & Percent & Number & Percent & Number & Percent \\
\hline Higher priced & 105,463 & 18.88 & 535,004 & 50.90 & 465,154 & 43.75 & 62,461 & 16.05 \\
\hline \multicolumn{9}{|l|}{ Lower priced } \\
\hline \multicolumn{9}{|l|}{$\begin{array}{l}\text { Sold to Fannie Mae or Freddie Mac } \\
\text { Combined with junior-lien loan }\end{array}$} \\
\hline $\begin{array}{l}\text { Total is above the conforming } \\
\text { loan size } \ldots \ldots \ldots \ldots \ldots \ldots \ldots\end{array}$ & 4,503 & .81 & 7,691 & .73 & 10,154 & .95 & 16,546 & 4.25 \\
\hline $\begin{array}{l}\text { Total is less than or equal to the } \\
\text { conforming loan size } \ldots \ldots \ldots \ldots\end{array}$ & 55,233 & 9.89 & 76,804 & 7.31 & 121,821 & 11.46 & 103,831 & 26.68 \\
\hline $\begin{array}{l}\text { Not sold to Fannie Mae or Freddie Mac } \\
\text { Above the conforming loan size } \ldots \ldots \ldots \ldots . . . .\end{array}$ & 62,104 & 11.12 & 60,666 & 5.77 & 57,138 & 5.37 & 32,301 & 8.30 \\
\hline $\begin{array}{l}\text { Less than or equal to the conforming loan size } \\
\text { Combined with junior-lien loan }\end{array}$ & & & & & & & & \\
\hline $\begin{array}{l}\text { Total is above the conforming } \\
\text { loan size } \ldots \ldots \ldots \ldots \ldots \ldots \ldots\end{array}$ & 40,725 & 7.29 & 43,734 & 4.16 & 42,704 & 4.02 & 23,761 & 6.11 \\
\hline $\begin{array}{l}\text { Total is less than or equal to the } \\
\text { conforming loan size } \ldots \ldots . . .\end{array}$ & 290,602 & 52.02 & 327,270 & 31.13 & 366,306 & 34.45 & 150,254 & 38.61 \\
\hline Total lower priced & 453,167 & 81.12 & 516,165 & 49.10 & 598,123 & 56.25 & 326,693 & 83.95 \\
\hline Total & 558,630 & 100 & $1,051,169$ & 100 & $1,063,277$ & 100 & 389,154 & 100 \\
\hline
\end{tabular}

NoTE: In piggyback lending, borrowers simultaneously receive a first-lien loan and a junior-lien (piggyback) loan to purchase a home from the same lender. For definitions of higher- and lower-priced lending, see text note 7; for explanation of the conforming loan size established for most loan purchases by Fannie Mae and Freddie Mac, see note 3, table 6; for definition of jumbo loans, see note 4 , table 6 .

priced first-lien loans, which fell 87 percent. This development was consistent with, and indeed part of, the more general mortgage market turmoil in 2007.

Piggyback lending and mortgage market difficulties. Piggyback loans have contributed to the current mortgage market difficulties. As noted, many home purchases financed with piggyback loans were used to minimize the cash contributions of borrowers toward the purchase of the property. Because loan arrangements involve little borrower equity at the time of purchase, if housing prices fall, as they have in many areas of the country for the past year or so, borrowers may find that they owe more on their combined firstand junior-lien loans than the value of the property. Borrowers in these circumstances are much more likely to default than those with an equity stake in the property. ${ }^{21}$

Piggyback loan arrangements also can make it much more difficult to work out loan difficulties should borrowers fall behind on their loan payments. If property values have fallen below the amount owed on the combined loans, the junior-lien holder often has little prospect of recovering any money if the property is sold-either through a short sale or as a consequence of foreclosure. If the holders of the first-

21. See Ronel Elul (2006), "Residential Mortgage Default," Federal Reserve Bank of Philadelphia, Business Review (Third Quarter), pp. 21-30; and Kerry D. Vandell (1995), "How Ruthless Is Mortgage Default? A Review and Synthesis of the Evidence," Journal of Housing Research, vol. 6 (2), pp. 245-64. and junior-lien loans are different parties, the interests of the two loan holders may conflict, and the juniorlien holder may have little interest in working with the borrower or the holder of the first lien on a short sale or loan modification unless the first-lien holder provides the junior-lien holder with some financial incentive.

Little information is available on the frequency with which holders of first liens and junior liens differ. The HMDA data provide an opportunity to examine the relationships among loan holders in piggyback loan arrangements, as the data include information on whether or not a reported loan was held in portfolio or sold; if the loan was sold, the data also indicate the type of purchaser.

The analysis here divides lenders into groups based on the type of originator. The analysis focuses on piggyback loan transactions in which the first- and junior-lien loans were used to buy a property and the dates of the loan originations occurred in the first 10 months of the calendar year. The date restriction addresses the concern that loan sales may not be immediate and that originations near the end of the year that are reported in the data as retained in portfolio may not be, as at least some of the loan sales do not occur until the next calendar year. Because the pattern of loan holding and sale may differ by the credit risk embedded in the loans, the analysis is conducted separately for home-purchase transactions in which the first-lien loan was higher priced (table 9).

For each group, the analysis indicates the proportion of loan originations in which the lender held both 
9. Distribution of lower- and higher-priced first-lien loans in piggyback loan transactions involving home purchases, by type of lender and lien status of loan that lender held at year-end, 2004-07

Percent

\begin{tabular}{|c|c|c|c|c|}
\hline \multirow{2}{*}{$\begin{array}{l}\text { Lien status of loan } \\
\text { that lender held } \\
\text { at year-end }\end{array}$} & \multicolumn{4}{|c|}{ Type of lender } \\
\hline & Depository & $\begin{array}{l}\text { Mortgage company } \\
\text { affiliate of } \\
\text { depository }\end{array}$ & $\begin{array}{l}\text { Independent } \\
\text { mortgage } \\
\text { company }\end{array}$ & Total \\
\hline & \multicolumn{4}{|c|}{ Lower-priced first-lien loans involved in piggyback loan transactions } \\
\hline $\begin{array}{l}2004 \\
\text { First lien and junior lien }\end{array}$ & 313 & 135 & 104 & 172 \\
\hline $\begin{array}{l}\text { First lien and junior lien } \\
\text { First lien only .......... }\end{array}$ & $\begin{array}{l}31.3 \\
29.8\end{array}$ & $\begin{array}{l}13.0 \\
21.0\end{array}$ & $\begin{array}{r}10.4 \\
5.4\end{array}$ & 15.4 \\
\hline Junior lien only & 11.5 & 2.8 & & 5.8 \\
\hline \multicolumn{5}{|l|}{ Neither $^{1}$} \\
\hline Different purchaser type & 6.9 & 32.3 & 12.7 & 14.4 \\
\hline Same purchaser type $\ldots$ & 20.5 & 30.4 & 67.9 & 47.3 \\
\hline & 100 & 100 \\
\hline $\begin{array}{l}\text { Percentage of piggyback } \\
\text { loan originations ....... }\end{array}$ & 29.7 & 17.2 & 53.0 & 100 \\
\hline \multicolumn{5}{|l|}{2005} \\
\hline First lien and junior lien & 38.4 & 20.0 & 10.7 & 21.6 \\
\hline First lien only .......... & 33.8 & 25.1 & 2.8 & 17.2 \\
\hline Junior lien only . & 3.2 & 3.5 & 5.2 & 4.2 \\
\hline \multicolumn{5}{|l|}{ Neither $^{1}$ (n)........... } \\
\hline Different purchaser type & 6.6 & 23.2 & 12.4 & 12.5 \\
\hline Same purchaser type $\ldots$ & 18.0 & 28.2 & 68.9 & 44.5 \\
\hline \multicolumn{4}{|l|}{ MEMO } & 100 \\
\hline $\begin{array}{l}\text { Percentage of piggyback } \\
\text { loan originations ...... }\end{array}$ & 32.9 & 18.7 & 48.4 & 100 \\
\hline \multicolumn{5}{|l|}{2006} \\
\hline First lien and junior lien & 35.7 & 11.1 & 20.7 & 23.6 \\
\hline First lien only . . . . . . . & 38.3 & 21.5 & 5.2 & 19.5 \\
\hline Junior lien only & 1.8 & 6.1 & 1.9 & 2.8 \\
\hline \multicolumn{5}{|l|}{ Neither $^{1}$} \\
\hline Different purchaser type & 8.9 & 35.8 & 11.8 & 16.0 \\
\hline Same purchaser type $\ldots$ & 15.3 & 25.5 & 60.4 & 38.1 \\
\hline MEMo & 100 & 100 & 100 & 100 \\
\hline $\begin{array}{l}\text { Percentage of piggyback } \\
\text { loan originations ...... }\end{array}$ & 32.9 & 21.3 & 45.8 & 100 \\
\hline \multicolumn{5}{|l|}{2007} \\
\hline First lien and junior lien & 40.9 & 7.2 & 19.3 & 28.3 \\
\hline First lien only ......... & 43.0 & 67.2 & 11.0 & 38.1 \\
\hline Junior lien only . & .5 & .4 & 1.3 & .7 \\
\hline \multicolumn{5}{|l|}{ Neither $^{1} \quad$............ } \\
\hline Different purchaser type & 7.3 & 12.8 & 11.7 & 9.6 \\
\hline Same purchaser type ... & 8.3 & 12.4 & 56.7 & 23.3 \\
\hline Total ................. & 100 & 100 & 100 & 100 \\
\hline \multicolumn{5}{|l|}{ MEMO } \\
\hline \multirow[t]{2}{*}{$\begin{array}{l}\text { Percentage of piggyback } \\
\text { loan originations } \ldots . . .\end{array}$} & 51.9 & 18.7 & 29.4 & 100 \\
\hline & \multicolumn{4}{|c|}{ Higher-priced first-lien loans involved in piggyback loan transactions } \\
\hline 2004 & & & & \\
\hline $\begin{array}{l}\text { First lien and junior lien } \\
\text { First lien only ......... }\end{array}$ & $\begin{array}{l}6.4 \\
3.4\end{array}$ & $\begin{array}{l}7.2 \\
2.9\end{array}$ & $\begin{array}{r}11.7 \\
7.5\end{array}$ & $\begin{array}{l}9.5 \\
5.7\end{array}$ \\
\hline Junior lien only & 2.2 & 1.7 & 1.5 & 1.7 \\
\hline \multicolumn{5}{|l|}{$\begin{array}{l}\text { Junlor lien only } \ldots \ldots \ldots \ldots \\
\text { Neither }^{1}\end{array}$} \\
\hline Different purchaser type & 8.4 & 42.6 & 6.3 & 12.3 \\
\hline Same purchaser type $\ldots$. & 79.5 & 45.7 & 73.0 & 70.8 \\
\hline $\begin{array}{l}\text { Total } \ldots \ldots \ldots \ldots \ldots \ldots \ldots \ldots \ldots \\
\text { Мвмо }\end{array}$ & 100 & 100 & 100 & 100 \\
\hline \multicolumn{5}{|l|}{$\begin{array}{l}\text { MEMO } \\
\text { Percentage of piggyback }\end{array}$} \\
\hline loan originations ...... & 28.7 & 14.9 & 56.3 & 100 \\
\hline 2005 & & & & \\
\hline First lien and junior lien & 20.7 & 14.7 & 16.5 & 17.1 \\
\hline First lien only ........... & 25.1 & 16.7 & 4.4 & 10.7 \\
\hline Junior lien only & 1.5 & 1.7 & 4.5 & 3.5 \\
\hline Neither $^{1}$. ........... & & & & \\
\hline Different purchaser type & 2.4 & 22.7 & 14.1 & 13.1 \\
\hline 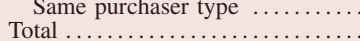 & $\begin{array}{c}50.3 \\
100-3\end{array}$ & $\begin{array}{c}44.3 \\
100\end{array}$ & $\begin{array}{c}60.5 \\
100\end{array}$ & $\begin{array}{c}55.7 \\
100\end{array}$ \\
\hline MEMO & & & & \\
\hline Percentage of piggyback & 205 & 162 & 633 & 100 \\
\hline
\end{tabular}


9. Distribution of lower- and higher-priced first-lien loans in piggyback loan transactions involving home purchases, by type of lender and lien status of loan that lender held at year-end, 2004-07-Continued

Percent

\begin{tabular}{|c|c|c|c|c|}
\hline \multirow[b]{2}{*}{$\begin{array}{l}\text { Lien status of loan } \\
\text { that lender held } \\
\text { at year-end }\end{array}$} & \multicolumn{4}{|c|}{ Type of lender } \\
\hline & Depository & $\begin{array}{l}\text { Mortgage company } \\
\text { affiliate of } \\
\text { depository }\end{array}$ & $\begin{array}{l}\text { Independent } \\
\text { mortgage } \\
\text { company }\end{array}$ & Total \\
\hline \multicolumn{5}{|l|}{2006} \\
\hline First lien and junior lien & 15.1 & 9.8 & 13.9 & 13.3 \\
\hline First lien only $\ldots \ldots \ldots \ldots$ & 10.5 & 21.5 & 6.4 & 10.6 \\
\hline Junior lien only $\ldots \ldots \ldots \ldots$. & .9 & 2.6 & 1.7 & 1.7 \\
\hline \multicolumn{5}{|l|}{ Neither $^{1}$ of } \\
\hline Different purchaser type & 6.2 & 10.0 & 12.5 & 10.5 \\
\hline Same purchaser type .... & 67.2 & 56.1 & 65.5 & 63.9 \\
\hline 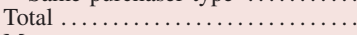 & 100 & 100 & 100 & 100 \\
\hline \multicolumn{5}{|l|}{ МЕмо } \\
\hline \multicolumn{3}{|l|}{ Percentage of piggyback } & 55.2 & 100 \\
\hline \multicolumn{5}{|l|}{2007} \\
\hline First lien and junior lien & 60.2 & 64.2 & 28.0 & 52.6 \\
\hline First lien only $\ldots \ldots \ldots \ldots$ & 12.5 & 8.0 & 2.7 & 8.0 \\
\hline Junior lien only $\ldots \ldots \ldots \ldots$ & 1.8 & 1.7 & 4.5 & 2.5 \\
\hline \multicolumn{5}{|l|}{ Neither ${ }^{1}$} \\
\hline Different purchaser type & 7.0 & .7 & 5.4 & 4.1 \\
\hline Same purchaser type ... & 18.5 & 25.4 & 59.5 & 32.7 \\
\hline Total ................. & 100 & 100 & 100 & 100 \\
\hline \multirow{2}{*}{\multicolumn{5}{|c|}{$\begin{array}{l}\text { МЕмо } \\
\text { Percentage of piggyback }\end{array}$}} \\
\hline & & & & \\
\hline \multirow[t]{2}{*}{ loan originations....} & 33.3 & 38.5 & 28.2 & 100 \\
\hline & \multicolumn{4}{|c|}{ Total } \\
\hline 2004 & & & & \\
\hline First lien and junior lien & 27.7 & 12.7 & 10.6 & 16.0 \\
\hline First lien only ......... & 26.0 & 18.6 & 5.7 & 13.9 \\
\hline Junior lien only $\ldots \ldots \ldots$ & 10.2 & 2.7 & 3.2 & 5.2 \\
\hline \multicolumn{5}{|l|}{ Neither $^{1}$} \\
\hline Different purchaser type & 7.2 & 33.6 & 11.7 & 14.1 \\
\hline Same purchaser type ... & 29.0 & 32.4 & 68.7 & 50.8 \\
\hline 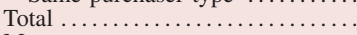 & 100 & 100 & 100 & 100 \\
\hline МЕMо & & & & \\
\hline Percentage of piggyback & & & & \\
\hline loan originations $\ldots \ldots \ldots \ldots \ldots$ & 29.6 & 16.9 & 53.5 & 100 \\
\hline 2005 & & & & \\
\hline First lien and junior lien. & 31.4 & 17.5 & 14.1 & 19.3 \\
\hline First lien only $\ldots \ldots \ldots \ldots \ldots$ & 30.4 & 21.1 & 3.8 & 13.8 \\
\hline Junior lien only $\ldots \ldots \ldots \ldots$ & 2.6 & 2.6 & 4.8 & 3.8 \\
\hline Neither $^{1}$ & 93.9 & 58.1 & 76.2 & 36.9 \\
\hline Different purchaser type & & & & \\
\hline Same purchaser type $\ldots$ & 5.0 & 23.0 & 13.4 & 12.8 \\
\hline Total .................... & 30.7 & 35.9 & 64.0 & 50.3 \\
\hline Мемо & & & & \\
\hline Percentage of piggyback & & & & \\
\hline loan originations $\ldots . .$. & 26.6 & 17.4 & 56.0 & 100 \\
\hline 2006 & & & & \\
\hline First lien and junior lien & 28.3 & 10.5 & 17.4 & 19.0 \\
\hline 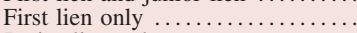 & 28.3 & 21.5 & 5.8 & 15.6 \\
\hline Junior lien only $\ldots \ldots \ldots \ldots \ldots$ & 1.5 & 4.5 & 1.8 & 2.3 \\
\hline Neither $^{1}$ & & & & \\
\hline Different purchaser type $\ldots \ldots \ldots$ & 7.9 & 24.3 & 12.1 & 13.5 \\
\hline Same purchaser type $\ldots . . . \ldots . .$. & 33.9 & 39.2 & 62.9 & 49.5 \\
\hline 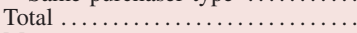 & 100 & 100 & 100 & 100 \\
\hline МЕMо & & & & \\
\hline Percentage of piggyback & & & & \\
\hline loan originations ..... & 28.6 & 21.5 & 49.9 & 100 \\
\hline 2007 & & & & \\
\hline First lien and junior lien $\ldots \ldots \ldots$ & 43.2 & 24.0 & 20.7 & 32.4 \\
\hline First lien only $\ldots \ldots \ldots \ldots \ldots \ldots$ & 39.4 & 49.7 & 9.6 & 33.0 \\
\hline Junior lien only $\ldots \ldots \ldots \ldots \ldots \ldots$ & .6 & .8 & 1.8 & 1.0 \\
\hline Neither $^{1}$ & & & & \\
\hline Different purchaser type & 7.3 & 9.2 & 10.7 & 8.7 \\
\hline Same purchaser type .... & 9.5 & 16.3 & 57.2 & 24.9 \\
\hline Total ................. & 100 & 100 & 100 & 100 \\
\hline МЕMо & & & & \\
\hline Percentage of piggyback & & & & \\
\hline loan originations ..... & 48.8 & 22.0 & 29.2 & 100 \\
\hline
\end{tabular}

Note: For definition of piggyback lending, see note to table 8; for definitions of lower- and higher-priced lending, see text note 7.

1. For purchaser types, see appendix A in the text. 
the first-lien loan and the piggyback loan at the end of the year or the incidence in which the loan holders differed. The following three lender categories are considered: (1) depository institutions, (2) mortgage company affiliates of depositories, and (3) independent mortgage companies. The analysis examines loan originations from 2004 through 2007 (excluding originations from the final two months of each year). The analysis focuses on these four years because data on lien status were not included in the HMDA data for the years before 2004 .

As mentioned earlier, the mortgage market turmoil that deepened greatly during 2007 affected many aspects of the market, including the market for piggyback loans. The HMDA data reflect these events. Regarding piggyback lending patterns, relationships found in 2004, 2005, and 2006 are in some respects similar to, but in others notably different from, relationships found in 2007. For example, independent mortgage companies were a significant source of piggyback credit until 2007. Before 2007, independent mortgage companies extended between 46 percent and 53 percent of the lower-priced piggyback loans and, depending on the year, between 55 percent and 63 percent of the higher-priced piggyback loans. From 2004 to 2006, depository institutions accounted for about 30 percent of the lower-priced piggyback loans and about 20 percent to more than 28 percent of the higher-priced piggyback loans. In 2007, the depositories accounted for a much larger share of the piggyback loans that were reported-about 52 percent of such loans that were lower priced and about 33 percent of those that were higher priced.

The HMDA data indicate that in most piggyback loan transactions one or both loans were sold by the lender. Overall, for loans originated in 2004, 2005, or 2006, both loans in higher-priced piggyback transactions were held in portfolio less than 20 percent of the time. For lower-priced piggyback transactions, both loans were held in portfolio somewhat more often. The experience in 2007 was different, particularly regarding piggyback transactions in which the firstlien loan was higher priced: Here, in more than one-half of the transactions, both loans were held in the originating institutions' portfolios. The relatively low incidence of piggyback loan holding for loans originated before 2007 means that for those loan transactions in which defaults occur, loss mitigation problems are likely to be more difficult.

Patterns of loan holding or sale differ some by originator. For each of the years considered, depository institutions were more likely than independent mortgage companies to hold in portfolio both loans in a piggyback loan transaction. For example, in 2006, depositories held both loans in lower-priced piggyback transactions about 36 percent of the time; independent mortgage companies held both loans about 21 percent of the time. Also, in 2006, depositories were more likely than other originators to hold in portfolio both loans in a piggyback transaction when the first-lien loan was higher priced. In 2007, the likelihood of a depository's holding both loans in portfolio when the first-lien loan was higher priced increased substantially, from about 15 percent of the transactions in 2006 to about 60 percent. Mortgage company affiliates of depositories also experienced a similar substantial increase in the incidence of holding both loans in a piggyback transaction involving higher-priced first-lien loans: The incidence rose from 10 percent in 2006 to 64 percent in 2007.

\section{Loans Covered by HOEPA}

Under HOEPA, certain types of mortgage loans that have rates or fees above specified levels require additional disclosures to consumers and are subject to various restrictions on loan terms. Under the 2002 revisions to Regulation C, the expanded HMDA data include a code to identify whether a loan is subject to the protections of HOEPA. 22

Before the release of the 2004 data, little information was publicly available about the extent of HOEPA-related lending or the number or types of institutions involved in that activity. ${ }^{23}$ For 2007, roughly 1,050 lenders reported extending about 11,500 loans covered by HOEPA (data not shown in tables). Only 11 lenders made 100 or more HOEPA loans, and most lenders did not report any such loans (data not shown in tables). In the aggregate, HOEPA-related lending accounts for a very small proportion of the mortgage market: HOEPA loans made up less than 0.2 percent of all the originations of home-secured refinancings and home-improvement loans reported for 2007 (data derived from table 3). ${ }^{24}$

22. This reporting requirement relates to whether the loan is subject to the original protections of HOEPA, as determined by the coverage test in the Federal Reserve Board's Regulation Z, 12 C.F.R. pt. 226.32(a). The required reporting is not triggered by the more recently adopted protections for "higher-priced mortgage loans" under Regulation $\mathrm{Z}$, notwithstanding that those protections were adopted under authority given to the Board by HOEPA. See 73 Federal Register 44522 (July 30, 2008).

23. Although the expanded HMDA data provide important new information, the data do not capture all HOEPA-related lending. Some HOEPA loans are extended by institutions not covered by HMDA, and some HOEPA loans made by HMDA-covered institutions are not reported under Regulation C, which implements HMDA. The extent of HOEPA-related lending not reported under HMDA is unknown.

24. HOEPA does not apply to home-purchase loans. 


\section{The 2007 HMDA Data on Loan Pricing}

The following sections assess the loan-pricing information in the 2007 HMDA data. The analysis considers changes in the incidence of higher-priced lending, APR spreads paid on loans above the price-reporting thresholds, and a description of the institutions involved in higher-priced lending.

\section{Factors That Influence Higher-Priced Lending}

The reported incidence of higher-priced lending under HMDA can be affected by three broad factors (to be explained shortly) that are related to mortgage market conditions and the general economic environment prevailing in a given year. In addition, the extent of nonreporting by lenders that cease operations during, or shortly after the end of, a calendar year can influence the incidence of higher-priced lending.

The three broad, market-environment-related factors that influence the incidence of higher-priced lending are (1) changes in the interest rate environment, particularly changes in short-term rates relative to longer-term rates; (2) changes in the business practices of mortgage lenders and investors, particularly in the array of products offered and the willingness or ability of the parties to bear credit risk (for example, the willingness to offer loans with high loan-to-value ratios or adjustable-rate loans with initial discounted interest rates); and (3) changes in the borrowing practices and perceptions of consumers (such as changes in preferences for investment properties or in perceptions of future house price movements) or in consumers' credit-risk profiles (for example, changes in the distribution of credit risks for those seeking and obtaining loans).

Aside from the effects that these broad economic factors may have on the incidence of higher-priced lending, changes in the number, size, and product offerings of reporters can matter. Of particular import for users of the HMDA data are the effects on the incidence of higher-priced lending of lenders that extended loans during a portion of 2007 but ceased operations during that year or in early 2008 and, consequently, did not report any data to the FFIEC. In most years, nonreporting has little effect on the HMDA data overall or on any particular aspect of the data. But, as discussed later, it has a significant influence on the 2007 data because the institutions that ceased operations were generally focused on higher-priced loans, and some of these lenders extended large numbers of such loans in previous years.

\section{Incidence of Higher-Priced Lending}

As in earlier years, most loans reported in 2007 were not higher priced as defined under Regulation C. Among all the HMDA-reported loans, 18.3 percent were higher priced in 2007 , down significantly from 28.7 percent in 2006 (data for 2007 shown in table 3; data for 2006 not shown). The incidence of higherpriced lending fell or was little changed across all loan product categories.

A number of factors account for the decline in the incidence of higher-priced lending as measured in the HMDA data. After increasing mildly in the first part of 2007, interest rates generally fell during the remainder of 2007 and ended the year well below the initial levels; the decrease likely contributed to the observed decline from 2006 in the incidence of higher-priced loans reported in 2007. Previous analyses of changing patterns in the reported incidence of higher-priced lending from 2004 through 2005 found that increases in short-term interest rates relative to longer-term rates help explain a portion of the increase over the period in the incidence of higherpriced lending, as more higher-risk adjustable-rate loans moved above the HMDA price-reporting thresholds. ${ }^{25}$ From 2006 to 2007, the pattern reversed as short-term rates fell more than longer-term rates, which suggests that some higher-risk adjustable-rate loans likely fell below the HMDA price-reporting thresholds. However, given the magnitude of the difficulties in the mortgage and housing markets, it seems very likely that changes in lender and investor circumstances and risk tolerances, changes in borrower conditions and preferences, and nonreporting by certain lenders explain most of the reported decline in the incidence of higher-priced lending. ${ }^{26}$

\section{Rate Spreads for Higher-Priced Lending}

Most higher-priced loans have APR spreads within 1 or 2 percentage points of the HMDA reporting thresholds. For example, for higher-priced conventional first-lien loans for owner-occupied site-built

25. See Avery, Brevoort, and Canner, "Higher-Priced Home Lending and the 2005 HMDA Data."

26. Some of the change in lender behavior may stem from regulatory guidance provided by the bank regulatory agencies to banking institutions regarding their subprime and nontraditional lending activities. See Board of Governors of the Federal Reserve System (2007), "Federal Financial Regulatory Agencies Issue Final Statement on Subprime Mortgage Lending," press release, June 29, www.federalreserve.gov/newsevents/press/bcreg/20070629a.htm; and Board of Governors of the Federal Reserve System (2006), "Federal Financial Regulatory Agencies Issue Final Guidance on Nontraditional Mortgage Product Risks," press release, September 29, www.federalreserve.gov/newsevents/press/bcreg/20060929a.htm. 
homes, two-thirds of the loans have spreads within 2 percentage points of the reporting threshold (table 3 ).

As in earlier years, only a relatively small proportion of first-lien loans have very large spreads7 percentage points or more. Similarly, only a relatively small proportion of junior-lien loans have spreads of 9 percentage points or more.

\section{Lenders and Higher-Priced Lending}

Most institutions covered by HMDA do little or no higher-priced lending. For 2007, 56 percent of the 8,610 reporting institutions extended fewer than 10 higher-priced loans, and 33 percent of them originated no higher-priced loans (table 10). At the other end of the spectrum, nearly 1,000 lenders reported making at least 100 higher-priced loans, and these institutions accounted for 94 percent of all such loans. The share of higher-priced lending attributable to the 10 lenders with the largest volume of higher-priced loans dropped from 59 percent in 2005 to 35 percent in 2006 and then to 31 percent in 2007 (data not shown in table).

\section{Higher-Priced Lending Specialists}

Another way to assess the higher-priced lending market is to examine the extent to which institutions that originate higher-priced loans may be considered "specialists" in that activity-that is, institutions that have a large proportion of their lending in the higherpriced category. Such specialized institutions can have a business orientation that is quite different from that of other lenders. For example, many of these institutions hold relatively few loans in portfolio and rely greatly on their ability to sell loans to the secondary market.

Taking 60 percent of loan originations as a benchmark for defining higher-priced specialists, the analy-

10. Higher-priced lending: Distribution by number of higher-priced loans extended and by the number and percent of HMDA reporters and higher-priced loans, 2007

\begin{tabular}{|c|c|c|c|c|}
\hline \multirow{2}{*}{$\begin{array}{l}\text { Number of } \\
\text { higher-priced } \\
\text { loans extended }\end{array}$} & \multicolumn{2}{|c|}{ HMDA reporters } & \multicolumn{2}{|c|}{ Higher-priced loans } \\
\hline & Number & Percent & Number & Percent \\
\hline 0 & 2,804 & 32.6 & 0 & .0 \\
\hline $1-4$. & 1,282 & 14.9 & 2,788 & .1 \\
\hline $5-9 \ldots$ & 726 & 8.4 & 4,925 & .3 \\
\hline $10-24$ & 1,212 & 14.1 & 19,425 & 1.0 \\
\hline $25-49$. & 881 & 10.2 & 31,127 & 1.6 \\
\hline $50-99 \ldots \ldots$ & 718 & 8.3 & 50,742 & 2.7 \\
\hline 100 or more & 987 & 11.5 & $1,798,767$ & 94.3 \\
\hline Total & 8,610 & 100 & $1,907,774$ & 100 \\
\hline
\end{tabular}

NoTE: For definition of higher-priced lending, see text note 7. HMDA Home Mortgage Disclosure Act of 1975. sis finds that 243 of the 987 lenders reporting at least 100 higher-priced loans, or about 3 percent of all reporting institutions, might be classified as specialists (data not shown in tables). These specialized lenders accounted for nearly 40 percent of all the higher-priced lending reported in the 2007 HMDA data.

\section{TURMOIL IN MORTGAGE MARKETS AND COVERAGE OF THE 2007 HMDA DATA}

Excluding government-backed lending, the HMDA data for 2007 show a substantial decline in mortgage lending activity from 2006 in all segments of the market. These declines are apparent whether the metric used to measure lending activity is loan applications, loan originations, loan purpose or type, or lending categorized by loan pricing. The HMDA data can be used to gauge the changes in lending activity by type of lender, population group, and geographies sorted along a number of dimensions, including demographic characteristics or measures of housing and mortgage market conditions.

\section{The Effects of Lenders That Ceased Operations}

As noted earlier, an issue when using the 2007 HMDA data is that some lenders ceased operations partway through 2007, yet none of their lending activity is included in the 2007 data because they did not report. As part of the HMDA data collection effort, staff members of the Federal Reserve Board track each financial institution that is expected to report (including all lenders that reported data for the previous calendar year) and contact, or attempt to contact, those that did not submit a report. ${ }^{27}$ In some cases, nonreporting is due to a cessation of business; in others, it is the result of a merger, acquisition, or consolidation. When a merger, acquisition, or consolidation occurs, all lending by the institutions covered by HMDA in that year is reported by the surviving entity; only when an institution goes out of business is the volume of reported loans possibly affected. In some cases, a business closure does not compromise the completeness of the HMDA data because some of the closed institutions report lending activity for the portion of the year in which they extended loans.

27. Sometimes contacting a nonreporting lender is impossible because the firm has ceased operations. 


\section{Measuring the Activity of Nonreporters}

The Federal Reserve's respondent tracking report records what happened to each institution that failed to report. For institutions that ceased operations, the tracking report also records, to the extent possible, the month that operations were discontinued. The tracking report indicates that 169 institutions that reported HMDA data for 2006 ceased operations during 2007 (or the very end of 2006) and did not report lending activity for 2007 (for a list of the institutions that ceased operations and did not report, see appendix table A.1, which has been posted separately as an Excel file). ${ }^{28}$ Of these institutions, two were subsidiaries of banking institutions, and the remainder were independent mortgage companies. (All other lenders that ceased operations in 2007 either reported data for 2007 or were merged or acquired, and their 2007 lending activity was reported by the surviving entity.)

It appears impossible to know how many loans these 169 institutions originated in 2007 before discontinuing operations. To help gauge their potential importance, an analysis of the lending activity of these institutions as recorded in the 2006 HMDA data was undertaken. Specifically, the 2006 HMDA data were reaggregated to exclude the lenders that ceased operations and did not report in 2007. Although many of these lenders extended relatively few loans ( 30 percent of the lenders extended fewer than 250 conventional first-lien loans for site-built properties in 2006), a few were among the nation's leading lenders in 2006. Moreover, some of these institutions were particularly active in the higher-priced segment of the home-purchase or refinance market. In the aggregate, these companies accounted for nearly 15 percent of the higher-priced conventional first-lien loans for site-built properties reported in 2006, and they accounted for about 8 percent of all conventional firstlien loans for such properties (data not shown in tables). ${ }^{29}$

\section{Time Pattern of Lending Activity}

The dates of loan origination reported in the HMDA data can be used to review the pattern of monthly loan extensions over the course of 2006 and 2007 to help distinguish the effects of the mortgage market turmoil on reported loan activity from the effects of closed lenders not reporting 2007 activity. For this analysis,

28. The list of lenders that ceased operations and did not report is as comprehensive as possible at this time. If additional information becomes available, the list will be updated.

29. Calculations exclude home-improvement loans and businessrelated loans. we focus on home-purchase and refinance lending for site-built properties. The volume of home-purchase originations peaked in June 2006 and declined over the rest of the year (figure 1). The pattern for refinancings was less consistent, as monthly originations varied over the course of the year, with high points reached in both March and October 2006.

Data for 2007 show a substantial falloff in activity from December 2006. The abrupt decline from December 2006 to January 2007 is likely a result of a combination of nonreporting by the 169 institutions that ceased operations and the mortgage and housing market turmoil in 2007 that caused most lenders to reduce origination activity. Among home-purchase loans, the greatest falloff in reported activity was in the higher-priced segment, in which originations dropped some 32 percent from December 2006 to January 2007. Overall, home-purchase lending fell

1. Volume of home-purchase and refinance loans originated: Higher- and lower-priced loans, and such loans excluding those originated by closed lenders, by month of origination, 2006-07

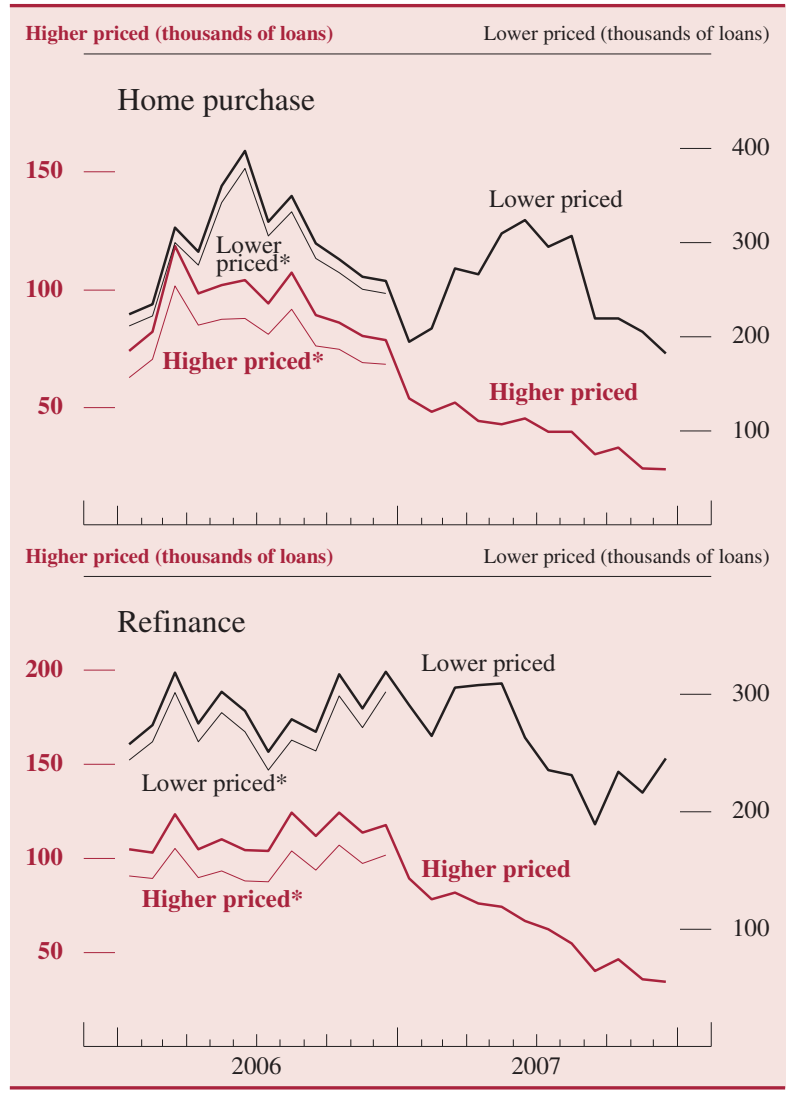

NotE: The data are monthly. Loans are conventional first-lien mortgages for site-built properties and exclude business loans. Closed lenders are lenders that reported data for 2006 under the Home Mortgage Disclosure Act (HMDA) but that subsequently ceased operations and did not report HMDA data for 2007. For definitions of higher- and lower-priced loans, see text note 7 .

* Excluding loans originated by closed lenders. 
27 percent over this period. A similar pattern was found for refinancings.

To better evaluate the effects of nonreporting on loan volumes in the early part of 2007, the loans of the 169 lenders that ceased operations and did not report were removed from the total loan volumes reflected in the 2006 HMDA data. Excluding these lenders reduces by about 25 percent the differences in the level of home-purchase (and refinance) lending reported between the end of 2006 and January 2007. The reduction is larger for the higher-priced loan segment (about 42 percent), a finding that reflects the greater focus of these institutions on that segment of the market. The fact that a large drop in lending activity is still observed after removing from the 2006 data the institutions that ceased operations indicates that most of the decline in reported lending from 2006 to 2007 was due to the effects of the market turmoil and not nonreporting.

\section{Higher-Priced Lending by Lender Type}

Lending activity can be described by type of lender. Four groups of lenders are considered here: depository institutions and three types of mortgage companies-namely, independents, direct subsidiaries of depository institutions, and affiliates of depository institutions. In 2004 and 2005, independent mortgage companies originated about one-half of the higher-priced conventional first-lien loans related to site-built homes and about 30 percent of all conventional first-lien loans (table 11). Depository institutions extended about one-fourth of the higher-priced

11. Distribution of higher-priced lending, by type of lender, and incidence at each type of lender, 2004-07

Percent except as noted

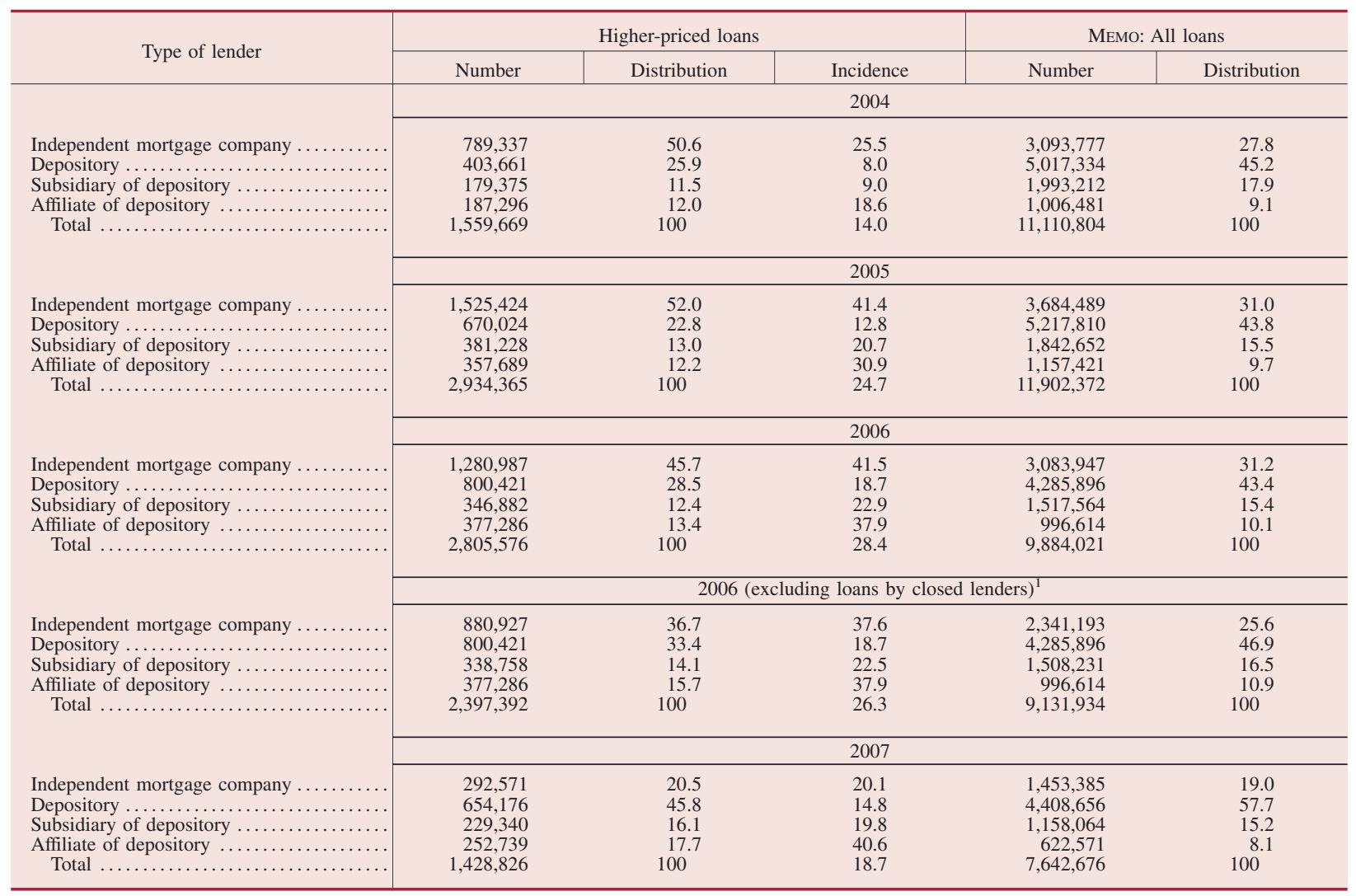

NOTE: Conventional first-lien mortgages for site-built properties; excludes business loans. For definition of higher-priced lending, see text note 7 .
1. Closed lenders are lenders that reported data for 2006 under the Home Mortgage Disclosure Act (HMDA) but that subsequently ceased operations and did not report HMDA data for 2007. 
loans and about 45 percent of all loans. The HMDA data for 2006 show that independent mortgage companies accounted for a somewhat smaller share of the higher-priced loan market (but a nearly equivalent share of the entire market): In that year, these companies extended 46 percent of the higher-priced loans and 31 percent of all loans.

As noted earlier, in 2007, turmoil in the subprime mortgage sector caused a number of lenders to cease operations, curtail their activities, or transfer their business to others; all but two of the institutions that ceased operations were independent mortgage companies. The HMDA data portray the diminished role of independent mortgage companies in the homelending market: In 2007, these companies originated 21 percent of the reported higher-priced loans and 19 percent of all loans.

The reduced role of the independent mortgage companies in the 2007 HMDA data is due partly to some of these lenders ceasing operations and partly to a curtailment of activity among surviving institutions of this type. Because the independent mortgage companies that ceased operations in 2007 did not report any activity, it is impossible to determine the magnitude of their lending in 2007. To help gauge their potential importance, the 2006 HMDA data were re-aggregated to exclude the independent mortgage companies that ceased operations during 2007 and did not report. Excluding these closed institutions reduces by some 31 percent the number of higherpriced loans originated by lenders in the independent mortgage company category in 2006 and raises by between about 14 percent and 17 percent the share of higher-priced lending accounted for by the other types of lenders in that year (data derived from table 11).

In the 2007 HMDA data, depository institutions are the leading providers of higher-priced loans. In part, this finding is a reflection of the sharp reduction in lending by independent mortgage companies (both those that continued to operate throughout 2007 and those that closed and did not report). The increased role of depository institutions in the higher-priced segment of the market is not an indication of expanded lending; the number of higher-priced loans that depository institutions extended in 2007 was some 18 percent below the corresponding total for 2006. Rather, the increased role of such institutions reflects the large contraction in activity of other institutions in this part of the market.
2006 Lending Profile of the 169 Closed Institutions That Did Not Report

One way to learn about the activities of the institutions that ceased operations in 2007 and did not report data is to examine the nature of their lending activities in 2006 and to compare it with the lending of the other reporting institutions for that year. For the analysis, lending activities are described by a wide range of borrower, location, and loan characteristics and by local housing or mortgage market conditions (table 12).

The analysis identifies many differences between the lending activities of the 169 institutions in 2006 and those of the other HMDA reporters. Most striking is the much higher incidence of higher-priced lending for the 169 institutions than for the other reporters. This difference is revealed in the profile of lending arrayed by either borrower income or by race or ethnicity of the borrower. For all income categories, the incidence of higher-priced lending for the 169 institutions is about double the rate for the other HMDA reporters. Also striking is the very high incidence of higher-priced lending for blacks ( 74 percent) and Hispanic whites (63 percent) among the 169 lenders. Regarding their overall lending, the 169 lenders extended a higher share of their loans to blacks and Hispanic whites than the other HMDA reporters, and they also extended a higher share of loans to borrowers in census tracts with larger fractions of minority populations or lower incomes.

In 2006, the 169 institutions tended to extend somewhat larger loans and nearly double the share of piggyback loans. The loans they originated also were more likely to be for properties in the western region of the country and in metropolitan areas that experienced greater recent declines in home values and greater increases in mortgage delinquencies.

\section{Changes in Lending Activity by Borrower and Geography}

The HMDA data can be used to track changes in mortgage market activity between 2006 and 2007 . Over this period, the mortgage market transitioned from one characterized by a relatively high incidence of higher-priced lending and of mortgage loan sales to one with a substantially lower share of both higherpriced lending and loans sold to the secondary mar- 
12. Distribution of all loans and of lower- and higher-priced loans, and incidence of lower- and higher-priced lending, for the 169 closed lenders and for all other lenders, by characteristic of borrower and of loan and by location of property, 2006

Percent

\begin{tabular}{|c|c|c|c|c|c|c|c|c|c|c|}
\hline \multirow{3}{*}{ Characteristic and status } & \multicolumn{5}{|c|}{ Closed lenders } & \multicolumn{5}{|c|}{ All other lenders } \\
\hline & \multirow{2}{*}{\begin{tabular}{|c} 
All loans \\
Distribution
\end{tabular}} & \multicolumn{2}{|c|}{ Lower-priced loans } & \multicolumn{2}{|c|}{ Higher-priced loans } & \multirow{2}{*}{\begin{tabular}{|c|} 
All loans \\
Distribution
\end{tabular}} & \multicolumn{2}{|c|}{ Lower-priced loans } & \multicolumn{2}{|c|}{ Higher-priced loans } \\
\hline & & Distribution & Incidence $^{1}$ & Distribution & Incidence $^{1}$ & & Distribution & Incidence $^{1}$ & Distribution & Incidence $^{1}$ \\
\hline \multicolumn{11}{|l|}{ BORROWER } \\
\hline \multirow{2}{*}{\multicolumn{11}{|c|}{$\begin{array}{l}\text { Income ratio (percent of area } \\
\text { median) } \\
\text { Lower }\end{array}$}} \\
\hline & 12.1 & 11.2 & 45.2 & 12.9 & 54.8 & 14.5 & 14.4 & 72.7 & 14.9 & 27.3 \\
\hline Middle $\ldots \ldots \ldots \ldots \ldots \ldots$ & 9.0 & 7.5 & 40.7 & 10.4 & 59.3 & 10.6 & 10.4 & 71.8 & 11.2 & 28.2 \\
\hline High ..... & 70.5 & 70.3 & 48.6 & 70.8 & 51.4 & 69.0 & 69.3 & 73.6 & 68.3 & 26.4 \\
\hline Missing $^{3}$ & 8.4 & 11.1 & 64.2 & 5.9 & 35.8 & 5.9 & 6.0 & 74.7 & 5.6 & 25.3 \\
\hline Total $\ldots$ & 100 & 100 & 48.8 & 100 & 51.2 & 100 & 100 & 73.3 & 100 & 26.7 \\
\hline \multicolumn{11}{|l|}{ Minority status ${ }^{4}$} \\
\hline Black or African American & 16.7 & 9.5 & 26.1 & 22.7 & 73.9 & 9.7 & 6.5 & 49.3 & 18.9 & 50.7 \\
\hline Hispanic white $\ldots \ldots \ldots \ldots$ & 22.1 & 17.8 & 36.6 & 25.8 & 63.4 & 14.6 & 12.5 & 63.0 & 20.7 & 37.0 \\
\hline Asian $\ldots \ldots \ldots \ldots \ldots$ & 4.3 & 5.2 & 55.1 & 3.5 & 44.9 & 4.5 & 5.1 & 83.4 & 2.9 & 16.6 \\
\hline Non-Hispanic white & 56.9 & 67.5 & 54.1 & 48.0 & 45.9 & 71.2 & 76.0 & 78.9 & 57.5 & 21.1 \\
\hline Total $^{5} \ldots \ldots \ldots \ldots$ & 100 & 100 & 45.6 & 100 & 54.4 & 100 & 100 & 73.9 & 100 & 26.1 \\
\hline \multicolumn{11}{|l|}{ Sex } \\
\hline Single female & 31.1 & 27.7 & 40.4 & 34.0 & 59.6 & 24.8 & 23.2 & 68.9 & 29.1 & 31.1 \\
\hline Single male $\ldots \ldots \ldots \ldots$ & 40.0 & 36.7 & 41.7 & 42.9 & 58.3 & 33.0 & 30.7 & 68.4 & 39.4 & 31.6 \\
\hline Joint female and male ${ }^{6}$ & 28.8 & 35.7 & 56.3 & 23.1 & 43.7 & 42.2 & 46.0 & 80.2 & 31.5 & 19.8 \\
\hline Total $^{5} \ldots \ldots \ldots \ldots$ & 100 & 100 & 45.5 & 100 & 54.5 & 100 & 100 & 73.5 & 100 & 26.5 \\
\hline \multicolumn{11}{|l|}{ LOAN } \\
\hline \multicolumn{11}{|l|}{$\begin{array}{l}\text { Amount of loan (thousands } \\
\text { of dollars) }\end{array}$} \\
\hline Less than $100 \ldots \ldots \ldots \ldots$ & 15.3 & 8.7 & 26.3 & 20.8 & 73.7 & 20.5 & 17.8 & 63.6 & 28.0 & 36.4 \\
\hline $100-249 \ldots \ldots$ & 49.0 & 50.4 & 47.3 & 47.9 & 52.7 & 48.0 & 48.5 & 74.2 & 46.4 & 25.8 \\
\hline 250 or more .... & 35.7 & 40.9 & 52.7 & 31.3 & 47.3 & 31.5 & 33.7 & 78.3 & 25.6 & 21.7 \\
\hline Total $^{5} \ldots$ & 100 & 100 & 46.0 & 100 & 54.0 & 100 & 100 & 73.3 & 100 & 26.7 \\
\hline \multicolumn{11}{|l|}{ Owner-occupancy status } \\
\hline Owner ................. & 85.1 & 85.1 & 46.0 & 85.0 & 54.0 & 86.2 & 86.3 & 73.4 & 86.2 & 26.6 \\
\hline Non-owner ${ }^{7}$. & 14.9 & 14.9 & 45.9 & 15.0 & 54.1 & 13.8 & 13.7 & 73.2 & 13.8 & 26.8 \\
\hline $\operatorname{Total}^{5} \ldots$ & 100 & 100 & 46.0 & 100 & 54.0 & 100 & 100 & 73.3 & 100 & 26.7 \\
\hline \multicolumn{11}{|l|}{ Type of property } \\
\hline Manufactured home & $\begin{array}{r}99.6 \\
.4\end{array}$ & $\begin{array}{r}99.3 \\
.7\end{array}$ & $\begin{array}{l}43.9 \\
73.8\end{array}$ & $\begin{array}{r}99.8 \\
.2\end{array}$ & $\begin{array}{l}34.1 \\
26.2\end{array}$ & $\begin{array}{r}98.0 \\
2.0\end{array}$ & $\begin{array}{r}98.6 \\
1.4\end{array}$ & $\begin{array}{l}17.8 \\
49.9\end{array}$ & $\begin{array}{r}96.2 \\
3.8\end{array}$ & $\begin{array}{l}26.2 \\
50.1\end{array}$ \\
\hline Total $^{5} \ldots \ldots \ldots$ & $100^{.+4}$ & 100 & 46.0 & $100^{.2}$ & 54.0 & 100 & 100 & 73.3 & 100 & 26.7 \\
\hline \multicolumn{11}{|l|}{ Piggyback status } \\
\hline Piggyback $^{8} \ldots \ldots$ & 23.2 & 19.8 & 39.3 & 26.1 & 60.7 & 12.7 & 10.3 & 59.3 & 19.5 & 40.7 \\
\hline Not piggyback & 76.8 & 80.2 & 48.0 & 73.9 & 52.0 & 87.3 & 89.7 & 75.4 & 80.5 & 24.6 \\
\hline $\operatorname{Total}^{5} \ldots \ldots$ & 100 & 100 & 46.0 & 100 & 54.0 & 100 & 100 & 73.3 & 100 & 26.7 \\
\hline $\begin{array}{l}\text { LOCATION OF PROPERTY, } \\
\text { BY FREDDIE MAC REGION }\end{array}$ & & & & & & & & & & \\
\hline Northeast $\ldots \ldots \ldots \ldots \ldots$ & 18.9 & 19.5 & 46.9 & 18.3 & 53.1 & 22.1 & 22.6 & 74.9 & 20.8 & 25.1 \\
\hline Southeast .... & 20.8 & 18.3 & 39.8 & 22.9 & 60.2 & 22.1 & 21.2 & 70.6 & 24.4 & 29.4 \\
\hline North Central & 13.1 & 10.3 & 35.5 & 15.5 & 64.5 & 16.7 & 16.4 & 72.0 & 17.5 & 28.0 \\
\hline Southwest .... & 12.7 & 12.1 & 43.2 & 13.1 & 56.8 & 13.7 & 13.2 & 70.6 & 15.1 & 29.4 \\
\hline West ...... & 34.5 & 39.8 & 52.2 & 30.2 & 47.8 & 25.5 & 26.6 & 76.7 & 22.3 & 23.3 \\
\hline Total $^{5} \ldots$ & 100 & 100 & 45.3 & 100 & 54.7 & 100 & 100 & 73.3 & 100 & 26.7 \\
\hline Census Tract of Property & & & & & & & & & & \\
\hline $\begin{array}{l}\text { Income ratio (percent of are } \\
\text { median })^{10}\end{array}$ & & & & & & & & & & \\
\hline 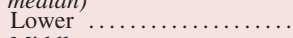 & 24.2 & 18.0 & 33.7 & 29.3 & 66.3 & 17.9 & 14.7 & 60.4 & 26.5 & 39.6 \\
\hline Middle .. & 49.2 & 48.4 & 44.4 & 49.9 & 55.6 & 50.9 & 50.2 & 72.2 & 53.1 & 27.8 \\
\hline High .... & 26.6 & 33.6 & 57.0 & 20.9 & 43.0 & 31.2 & 35.1 & 82.6 & 20.4 & 17.4 \\
\hline Total $^{5}$ & 100 & 100 & 45.2 & 100 & 54.8 & 100 & 100 & 73.3 & 100 & 26.7 \\
\hline
\end{tabular}

ket. As noted, a comparison of lending activity in these two years is complicated by an underreporting of loans in 2007 because some lenders went out of business during the year and did not report HMDA data. Most of the lenders that did not report data for 2007 exited the market by the middle of that year, and therefore underreporting of data is much less likely to be a problem for the last half of the year. Conse- quently, to reduce the uncertain effects of underreporting, we compare mortgage market activity in the first six months of 2006 with that in the last six months of 2007.

The comparison focuses primarily on the changes in the number of originated loans, although changes in the number of applications and of denials are also examined. Comparisons of loan originations are made 
12. Distribution of all loans and of lower- and higher-priced loans, and incidence of lower- and higher-priced lending, for the 169 closed lenders and for all other lenders, by characteristic of borrower and of loan and by location of property, 2006-Continued

Percent

\begin{tabular}{|c|c|c|c|c|c|c|c|c|c|c|}
\hline \multirow{3}{*}{ Characteristic and status } & \multicolumn{5}{|c|}{ Closed lenders } & \multicolumn{5}{|c|}{ All other lenders } \\
\hline & \multirow{2}{*}{\begin{tabular}{|c|} 
All loans \\
Distribution \\
\end{tabular}} & \multicolumn{2}{|c|}{ Lower-priced loans } & \multicolumn{2}{|c|}{ Higher-priced loans } & \multirow{2}{*}{$\frac{\text { All loans }}{\text { Distribution }}$} & \multicolumn{2}{|c|}{ Lower-priced loans } & \multicolumn{2}{|c|}{ Higher-priced loans } \\
\hline & & Distribution & Incidence $^{1}$ & Distribution & Incidence $^{1}$ & & Distribution & Incidence $^{1}$ & Distribution & Incidence $^{1}$ \\
\hline \multirow{2}{*}{\multicolumn{11}{|c|}{$\begin{array}{l}\text { Racial or ethnic composition } \\
\text { (minorities as a percent of } \\
\text { population) }\end{array}$}} \\
\hline & 22.0 & 23.9 & 49.0 & 20.5 & 51.0 & 32.4 & 34.5 & 78.0 & 26.7 & 22.0 \\
\hline $10-50 \ldots \ldots \ldots \ldots \ldots \ldots \ldots$ & 48.5 & 53.5 & 49.9 & 44.3 & 50.1 & 47.9 & 49.2 & 75.3 & 44.3 & 24.7 \\
\hline 50 or more... & 29.5 & 22.6 & 34.7 & 35.1 & 65.3 & 19.7 & 16.3 & 60.8 & 28.9 & 39.2 \\
\hline Total $^{5} \ldots$ & 100 & 100 & 45.2 & 100 & 100 & 100 & 100 & 73.3 & 100 & 26.7 \\
\hline \multicolumn{11}{|l|}{$\begin{array}{l}\text { Credit score of borrowers } \\
\text { (percent of mortgage } \\
\text { borrowers with scores } \\
\text { below } 600)^{11}\end{array}$} \\
\hline 20 or more ............. & 17.3 & 9.8 & 26.0 & 23.7 & 74.0 & 13.9 & 10.2 & 53.7 & 24.1 & 46.3 \\
\hline $10-20 \ldots \ldots \ldots \ldots \ldots$ & 32.8 & 30.0 & 42.1 & 35.2 & 57.9 & 30.6 & 28.5 & 68.4 & 36.3 & 31.6 \\
\hline Less than 10 & 49.9 & 60.1 & 55.5 & 41.1 & 44.5 & 55.5 & 61.3 & 81.0 & 39.6 & 19.0 \\
\hline Total $^{5} \ldots \ldots \ldots$ & 100 & 100 & 46.0 & 100 & 54.0 & 100 & 100 & 73.3 & 100 & 26.7 \\
\hline \multicolumn{11}{|l|}{ MSA OF PROPERTY } \\
\hline \multirow{2}{*}{\multicolumn{11}{|c|}{$\begin{array}{l}\text { Real price appreciation of } \\
\text { real estate (percent })^{12}\end{array}$}} \\
\hline-8 or less $\ldots \ldots \ldots \ldots . . . . .$. & & 55.9 & 46.4 & 53.6 & 53.6 & 44.3 & 44.4 & 73.6 & 44.3 & 26.4 \\
\hline$-8-0 \ldots \ldots \ldots \ldots \ldots \ldots$ & 33.8 & 32.4 & 43.6 & 34.9 & 56.4 & 41.9 & 41.8 & 73.5 & 42.1 & 26.5 \\
\hline 0 or more $\ldots \ldots \ldots \ldots \ldots$ & 11.6 & 11.7 & 45.7 & 11.6 & 54.3 & 13.8 & 13.8 & 74.0 & 13.6 & 26.0 \\
\hline $\operatorname{Total}^{5} \ldots \ldots \ldots \ldots \ldots$ & 100 & 100 & 45.4 & 100 & 54.6 & 100 & 100 & 73.6 & 100 & 26.4 \\
\hline \multicolumn{11}{|l|}{$\begin{array}{l}\text { Change in delinquincy rate } \\
{\text { (percent })^{13}}^{\text {pat }}\end{array}$} \\
\hline 0.5 or less $\ldots \ldots \ldots \ldots \ldots \ldots$ & 27.9 & 27.3 & 44.2 & 28.5 & 55.8 & 37.0 & 36.7 & 72.7 & 37.8 & 27.3 \\
\hline $0.5-2 \ldots \ldots \ldots \ldots \ldots \ldots \ldots$ & 44.9 & 43.0 & 43.3 & 46.5 & 56.7 & 42.9 & 42.4 & 72.3 & 44.5 & 27.7 \\
\hline 2 or more $\ldots \ldots \ldots \ldots \ldots \ldots$ & 27.2 & 29.7 & 49.5 & 25.1 & 50.5 & 20.1 & 20.9 & 76.4 & 17.8 & 23.6 \\
\hline Total $^{5}$ & 100 & 100 & 45.2 & 100 & 54.8 & 100 & 100 & 73.3 & 100 & 26.7 \\
\hline
\end{tabular}

NoTE: Conventional first-lien mortgages for home purchase or refinance for single-family houses; excludes business loans. For definition of closed lenders, see note 1, table 11; for definitions of lower- and higher-priced lending, see text note 7 .

1. Distribution sums horizontally.

2. Borrower income is the total income relied upon by the lender in the loan underwriting. Income is expressed relative to the median family income of the metropolitan statistical area (MSA) or statewide non-MSA in which the property being purchased is located. "Lower" is less than 80 percent of the median; "middle" is 80 percent to 119 percent; and "high" is 120 percent or more.

3. Information for income or property location was missing on the application.

4. Categories for race and ethnicity reflect the revised standards established in 1997 by the Office of Management and Budget. Applicants are placed under only one category for race and ethnicity, generally according to the race and ethnicity of the person listed first on the application. However, under race, the application is designated as joint if one applicant reported the single designation of white and the other reported one or more minority races. If the application is not joint but more than one race is reported, the following designations are made: If at least two minority races are reported, the application is designated as two or more minority races; if the first person listed on an application reports two races, and one is white, the application is categorized under the minority race. For loans with two or more applicants, lenders covered under the Home Mortgage Disclosure Act report data on only two.

5. Excludes loans for which the information for the characteristic was missing on the application and loans deemed business related or multifamily.

for both lower-priced and higher-priced loans. Within the category of higher-priced loans, differentiation is made by the size of the reported APR spread. Loans for home purchase and for refinancing are examined separately, and the analysis is restricted to first-lien loans secured by a site-built property. Unlike some of
6. On the applications for these loans, one applicant reported "male," and the other reported "female." For female and for male, only sole applicants were considered. Excludes loans for which sex was missing on the application and loans involving two females or two males.

7. Includes loans for which occupancy status was missing.

8. For definition of piggyback lending, see note to table 8.

9. Freddie Mac defines its regions as follows: Northeast: N.Y., N.J., Pa. Del., Md., D.C., Va., W.V., P.R., Maine, N.H., Vt., Mass., R.I., Conn., V.I.; Southeast: N.C., S.C., Tenn., Ky., Ga., Ala., Fla., Miss.; North Central: Ohio, Ind., Ill., Mich., Wis., Minn., Iowa, N.D., S.D.; Southwest: Texas, La., N.M. Okla., Ark., Mo., Kan., Colo., Neb., Wyo.; West: Calif., Ariz., Nev., Ore., Wash., Utah, Idaho, Mont., Hawaii, Alaska, Guam.

10. The income category of a census tract is the median family income of the tract relative to that of the metropolitan statistical area (MSA) or statewide non-MSA in which the tract is located. "Lower" is less than 80 percent of the median; "middle" is 80 percent to 119 percent; and "high" is 120 percent or more.

11. Data from Equifax drawn from credit records of individuals as of December 31,2006 . A score below 600 generally conforms with borrowers in the subprime portion of the mortgage market. Includes all borrowers with an outstanding mortgage regardless of the year in which the loan was taken out.

12. Housing price index from the Office of Federal Housing Enterprise Oversight. House price changes calculated using the percent change in the index from the fourth quarter of 2006 through the first quarter of 2008. Based on the change in median home values for a constant 2000-defined geography.

13. Delinquency rates from Trend Data, a product of TransUnion LLC. The change in the mortgage delinquency rate is calculated using delinquency rates from the fourth quarter of 2003 to the fourth quarter of 2007.

the earlier analyses, we do not differentiate between government-backed and conventional loans. Changes in the number of loan originations are examined by borrower race or ethnicity, borrower income, censustract income, and owner-occupancy status of the property securing the loan. 
13. Change in the number of loan applications, denials, and originations, and change in the number of lower- and higherpriced originations, for all loans and for jumbo loans, by characteristic of borrower and of census tract, 2006:H1 through 2007:H2

A. Home purchase

Percent

\begin{tabular}{|c|c|c|c|c|c|c|c|c|c|c|c|c|c|}
\hline \multirow{5}{*}{$\begin{array}{l}\text { Characteristic } \\
\text { of borrower and } \\
\text { of census tract, by } \\
\text { owner-occupancy } \\
\text { status of property }\end{array}$} & \multicolumn{2}{|c|}{ Applications } & \multicolumn{11}{|c|}{ Loans originated } \\
\hline & \multirow{4}{*}{$\begin{array}{c}\text { Number } \\
\text { acted } \\
\text { upon by } \\
\text { lender }\end{array}$} & \multirow{4}{*}{$\begin{array}{c}\text { Number } \\
\text { denied }\end{array}$} & \multirow{4}{*}{ All } & \multirow{4}{*}{$\begin{array}{l}\text { Lower } \\
\text { priced }\end{array}$} & \multirow{4}{*}{ All } & \multicolumn{3}{|c|}{ Higher priced } & \multirow{2}{*}{\multicolumn{5}{|c|}{ Jumbo }} \\
\hline & & & & & & \multicolumn{3}{|c|}{$\begin{array}{l}\text { Distribution, by percentage } \\
\text { points of APR spread }^{1}\end{array}$} & & & & & \\
\hline & & & & & & \multirow[b]{2}{*}{$3-3.99$} & \multirow[b]{2}{*}{$4-4.99$} & \multirow[b]{2}{*}{$\begin{array}{l}5 \text { or } \\
\text { more }\end{array}$} & \multicolumn{2}{|c|}{ Applications } & \multirow[b]{2}{*}{ All } & \multirow[b]{2}{*}{$\begin{array}{l}\text { Lower } \\
\text { priced }\end{array}$} & \multirow[b]{2}{*}{$\begin{array}{l}\text { Higher } \\
\text { priced }\end{array}$} \\
\hline & & & & & & & & & \begin{tabular}{|c|} 
Number \\
acted \\
upon by \\
lender
\end{tabular} & $\begin{array}{c}\text { Number } \\
\text { denied }\end{array}$ & & & \\
\hline \multicolumn{14}{|l|}{$\begin{array}{c}\text { OWNER OCCUPIED } \\
\text { BORROWER }\end{array}$} \\
\hline $\begin{array}{l}\text { Black or African American } \\
\text { Hispanic white } \ldots \ldots \ldots \ldots \\
\text { Other minority }{ }^{3} \ldots \ldots \ldots \ldots \\
\text { Non-Hispanic white } \ldots \ldots \ldots \\
\text { Missing }{ }^{4} \ldots \ldots \ldots \ldots \ldots \ldots\end{array}$ & $\begin{array}{l}-31.9 \\
-42.1 \\
-23.1 \\
-20.1 \\
-27.5\end{array}$ & $\begin{array}{l}-25.7 \\
-30.7 \\
-20.7 \\
-18.0 \\
-29.2\end{array}$ & $\begin{array}{l}-35.2 \\
-48.8 \\
-26.2 \\
-21.8 \\
-26.3\end{array}$ & $\begin{array}{r}-2.3 \\
-26.8 \\
-15.3 \\
-14.3 \\
-9.8\end{array}$ & $\begin{array}{l}-69.4 \\
-75.7 \\
-73.4 \\
-60.0 \\
-71.1\end{array}$ & $\begin{array}{r}11.2 \\
-25.0 \\
-24.7 \\
-11.4 \\
-11.2\end{array}$ & $\begin{array}{l}-46.7 \\
-66.4 \\
-71.2 \\
-47.6 \\
-56.0\end{array}$ & $\begin{array}{l}-89.0 \\
-94.0 \\
-93.1 \\
-88.5 \\
-91.1\end{array}$ & $\begin{array}{l}-37.3 \\
-57.3 \\
-35.9 \\
-31.7 \\
-31.5\end{array}$ & $\begin{array}{l}-10.7 \\
-32.5 \\
-26.9 \\
-12.1 \\
-19.0\end{array}$ & $\begin{array}{l}-57.2 \\
-72.8 \\
-43.4 \\
-40.2 \\
-38.8\end{array}$ & $\begin{array}{l}-39.7 \\
-65.1 \\
-36.2 \\
-37.1 \\
-31.2\end{array}$ & $\begin{array}{l}-74.5 \\
-83.1 \\
-75.6 \\
-62.3 \\
-71.4\end{array}$ \\
\hline \multicolumn{14}{|l|}{$\begin{array}{l}\text { Minority status, by income } \\
\text { category } 5\end{array}$} \\
\hline $\begin{array}{l}\text { Lower } \\
\text { Black or African American . }\end{array}$ & -30.8 & -30.3 & -30.0 & 5.2 & -65.7 & 43.7 & -32.8 & -88.0 & -15.0 & -7.4 & -25.9 & .0 & -87.5 \\
\hline Hispanic white $\ldots \ldots \ldots \ldots$ & -24.6 & -21.7 & -27.3 & -4.7 & -60.5 & -1.2 & -44.6 & -90.6 & -30.9 & -12.2 & -70.2 & -65.0 & -82.4 \\
\hline Other min & -14.0 & -12.0 & -16.4 & -6.0 & -61 & 6.1 & -54.6 & -90 & -36.5 & -30.5 & & -53.9 & -50 \\
\hline Non-Hispanic white & -19.8 & -20.3 & -20 & -11 . & -54 & 13.7 & -35.8 & -88 & -20 & 1 & & & -63 \\
\hline $\begin{array}{l}\text { Total } \ldots \ldots \ldots \ldots \ldots \ldots \ldots \\
\text { Middle }\end{array}$ & -22.9 & -24.1 & -22.6 & -9.2 & -59.2 & 15.4 & -38.0 & -88.9 & -26.9 & -13.3 & -42.6 & -37.8 & -70.0 \\
\hline Black or African American .. & -29.5 & -24.7 & -31.8 & 7.7 & -64.4 & 28.9 & -47.0 & -90.0 & -14.1 & 2.8 & -29.2 & -14.6 & -55.6 \\
\hline Hispanic white $\ldots \ldots \ldots \ldots$ & -36.9 & -28.8 & -42.1 & -13.1 & -70.3 & -6.4 & -64.0 & -94.7 & -44.4 & -29.6 & & & -80.5 \\
\hline Other $n$ & -17.5 & -14.7 & -20 & -8 & -7. & -3.1 & -68.9 & -93 & -27 & -11 & & & -80.3 \\
\hline Non-His & -20.0 & -19.7 & -21 & -12 & -71 & .6 & -49.7 & -90 & -33 & -12 & -4 & -40 & -56.9 \\
\hline \multicolumn{14}{|l|}{ High } \\
\hline Black or African American . & -31.8 & -20.3 & -38.7 & -6.9 & -72.9 & -.3 & -57.5 & -89.6 & -38.1 & -13.4 & -57.2 & -36.6 & -76.4 \\
\hline Hispanic whit & -48.8 & -35.4 & -57.3 & -35.8 & -81.5 & -29.7 & -75.1 & -94.7 & -57.7 & -34.3 & -72.9 & -64.3 & -83.9 \\
\hline Other minor & -23.6 & -23.9 & -27.0 & -15.8 & -77.1 & -23.9 & -75.9 & -93.6 & -34.6 & -27 & -42.0 & -34.4 & -75.7 \\
\hline Non-Hispanic white & -16.9 & -12.9 & -19 & -13.3 & -61 & -15 & -51.1 & -87 & -30 & -12 & -39 & -36 & -62.3 \\
\hline $\begin{array}{c}\text { Total } \\
\text { Missing }^{4}\end{array}$ & -23.9 & -21.7 & -26.6 & -14.6 & -71.3 & -17.6 & -61.9 & -90.9 & -35.9 & -20.6 & -44.9 & -37.7 & -73.6 \\
\hline Missing $^{4}$ & -61.6 & -36.4 & -68.4 & -67.7 & -70.3 & -70.2 & -64.8 & -80.7 & -51.2 & -2.9 & -64.3 & -64.6 & -63.6 \\
\hline \multicolumn{14}{|l|}{$\begin{array}{l}\text { Census TRACT OF PROPERTY } \\
\text { Income category }\end{array}$} \\
\hline Lower ..................... & -32.9 & -29.5 & -26.2 & -13.2 & -70.0 & -8.1 & -53.9 & -90.8 & -36.8 & -19.3 & -46.5 & -38.8 & -73.0 \\
\hline Middle . & -24.8 & -22.6 & -27.2 & -13.2 & -65.8 & -10.3 & -52.7 & -90.3 & -37.2 & -19.3 & -47.0 & -40.0 & -72.9 \\
\hline High $\ldots \ldots \ldots \ldots \ldots \ldots$ & -24.8 & -18.5 & -27.1 & -16.3 & -66.7 & -20.4 & -57.7 & -90.0 & -36.4 & -19.8 & -45.5 & -38.8 & -72.8 \\
\hline Total owner occupied ......... & -25.2 & -23.4 & -26.9 & -14.4 & -67.1 & -12.4 & -54.1 & -90.4 & -36.6 & -19.5 & -45.9 & -39.0 & -72.9 \\
\hline \multicolumn{14}{|l|}{ NON-OWNER OCCUPIED ${ }^{7}$} \\
\hline Total $\ldots \ldots \ldots \ldots \ldots \ldots \ldots$ & -38.2 & -29.2 & -41.5 & -32.6 & -64.5 & -52.0 & -57.1 & -86.1 & -37.5 & -25.3 & -44.5 & -40.2 & -64.7 \\
\hline Total . & -27.4 & -24.4 & -29.3 & -17.3 & -66.6 & -25.7 & -54.7 & -89.9 & -36.7 & -20.2 & -45.7 & -39.2 & -71.9 \\
\hline $\begin{array}{l}\text { Note: Conventional first-lien } \mathrm{m} \\
\text { business loans and applications, app } \\
\text { missing census-tract information. } \\
\text { lending, see text note } 7 \text {; for definiti } \\
\text { 1. See note } 1 \text {, table } 3 \text {. } \\
\text { 2. See note } 4 \text {, table } 12 \text {. }\end{array}$ & on of jumt & bo loans & e not & table & & $\begin{array}{l}\text { 5. See } \\
\text { 6. See } \\
\text { 7. Incl }\end{array}$ & $\begin{array}{l}\text { note } 2 \text {, ta } \\
\text { note } 10 \text {, } \\
\text { ades appli }\end{array}$ & $\begin{array}{l}\text { ble } 12 \text {. } \\
\text { ations an }\end{array}$ & $d$ loans for & r which oc & & tatus was & missing. \\
\hline
\end{tabular}

Changes in Lending Activity by Characteristic of Borrower and Census Tract

All borrower and census-tract groups, whether characterized by race or ethnicity, income, or owneroccupancy status, experienced a decline in the number of loan originations for home purchase and for refinancing (tables 13.A and 13.B, column 3). The percentage decline in loan originations was largest for
Hispanic whites and for blacks. For example, homepurchase loans to Hispanic white and black borrowers fell 49 percent and 35 percent respectively, while such loans to non-Hispanic white borrowers fell 22 percent over the same period. Even when changes for borrowers of similar income levels are compared, differences across racial or ethnic groups are found. However, the overall differences across income classes, whether 
13. Change in the number of loan applications, denials, and originations, and change in the number of lower- and higherpriced originations, for all loans and for jumbo loans, by characteristic of borrower and of census tract, 2006:H1 through 2007:H2—Continued

B. Refinance

Percent

\begin{tabular}{|c|c|c|c|c|c|c|c|c|c|c|c|c|c|}
\hline \multirow{5}{*}{$\begin{array}{l}\text { Characteristic } \\
\text { of borrower and } \\
\text { of census tract, by } \\
\text { owner-occupancy } \\
\text { status of property }\end{array}$} & \multicolumn{2}{|c|}{ Applications } & \multicolumn{11}{|c|}{ Loans originated } \\
\hline & \multirow{4}{*}{$\begin{array}{c}\text { Number } \\
\text { acted } \\
\text { upon by } \\
\text { lender }\end{array}$} & \multirow{4}{*}{$\begin{array}{c}\text { Number } \\
\text { denied }\end{array}$} & \multirow{4}{*}{ All } & \multirow{4}{*}{$\begin{array}{l}\text { Lower } \\
\text { priced }\end{array}$} & \multicolumn{4}{|c|}{ Higher priced } & \multirow{2}{*}{\multicolumn{5}{|c|}{ Jumbo }} \\
\hline & & & & & \multirow{3}{*}{ All } & \multicolumn{3}{|c|}{\begin{tabular}{|c|}
$\begin{array}{l}\text { Distribution, by percentage } \\
\text { points of APR } \text { spread }^{1}\end{array}$ \\
\end{tabular}} & & & & & \\
\hline & & & & & & & & & \multicolumn{2}{|c|}{ Applications } & \multirow[b]{2}{*}{ All } & \multirow[b]{2}{*}{$\begin{array}{l}\text { Lower } \\
\text { priced }\end{array}$} & \multirow[b]{2}{*}{$\begin{array}{l}\text { Higher } \\
\text { priced }\end{array}$} \\
\hline & & & & & & $3-3.99$ & $4-4.99$ & $\begin{array}{l}5 \text { or } \\
\text { more }\end{array}$ & \begin{tabular}{|c|} 
Number \\
acted \\
upon by \\
lender
\end{tabular} & $\begin{array}{c}\text { Number } \\
\text { denied }\end{array}$ & & & \\
\hline \multicolumn{14}{|l|}{$\begin{array}{c}\text { OWNER OCCUPIED } \\
\text { BORROWER }\end{array}$} \\
\hline $\begin{array}{l}\text { Black or African American } \\
\text { Hispanic white } \ldots \ldots \ldots \ldots \\
\text { Other minority }{ }^{3} \ldots \ldots \ldots \ldots \\
\text { Non-Hispanic white } \ldots \ldots \ldots \ldots \\
\text { Missing }{ }^{4} \ldots \ldots \ldots \ldots \ldots \ldots\end{array}$ & $\begin{array}{l}-18.3 \\
-15.7 \\
-12.2 \\
-15.6 \\
-29.4\end{array}$ & $\begin{array}{r}-.1 \\
19.1 \\
14.6 \\
-3.8 \\
-28.8\end{array}$ & $\begin{array}{l}-37.4 \\
-40.6 \\
-30.9 \\
-24.4 \\
-33.1\end{array}$ & $\begin{array}{l}-16.0 \\
-28.4 \\
-22.3 \\
-15.5 \\
-16.8\end{array}$ & $\begin{array}{l}-59.0 \\
-63.4 \\
-60.8 \\
-51.9 \\
-62.5\end{array}$ & $\begin{array}{l}-23.8 \\
-17.9 \\
-25.6 \\
-20.3 \\
-19.5\end{array}$ & $\begin{array}{l}-51.6 \\
-55.2 \\
-51.2 \\
-42.9 \\
-57.4\end{array}$ & $\begin{array}{l}-71.8 \\
-81.9 \\
-79.5 \\
-71.2 \\
-79.5\end{array}$ & $\begin{array}{l}-25.3 \\
-22.1 \\
-23.2 \\
-28.2 \\
-27.0\end{array}$ & $\begin{array}{r}15.0 \\
26.5 \\
16.2 \\
11.1 \\
-9.8\end{array}$ & $\begin{array}{l}-61.8 \\
-58.9 \\
-49.1 \\
-49.6 \\
-47.3\end{array}$ & $\begin{array}{l}-57.2 \\
-55.2 \\
-45.2 \\
-48.4 \\
-44.4\end{array}$ & $\begin{array}{l}-68.6 \\
-67.4 \\
-66.6 \\
-55.7 \\
-57.0\end{array}$ \\
\hline \multicolumn{14}{|l|}{$\begin{array}{l}\text { Minority status, by income } \\
\text { category } 5 \\
\text { Lower }\end{array}$} \\
\hline $\begin{array}{l}\text { Lower } \\
\text { Black or African American .. }\end{array}$ & -23.6 & -11.4 & -39.3 & -9.8 & -61.1 & -25.9 & -55.3 & -72.6 & 6.2 & 19.1 & -60.8 & -32.0 & -88.5 \\
\hline Hispanic white $\ldots \ldots \ldots \ldots$ & -16.2 & 4.0 & -35.5 & -14.3 & -66.0 & -22.6 & -58.0 & -82.6 & 20.3 & 42.4 & -54.2 & -39.2 & -90.5 \\
\hline Other minority $^{3} \ldots$ & -13.4 & -1.6 & -27.2 & -13.8 & -60.6 & -34.2 & -53.5 & -75.0 & 23.7 & 36.8 & -50.0 & -49.0 & -55.6 \\
\hline Non-Hispanic white & -24.6 & -19.4 & -29.9 & -18.7 & -54.8 & -22.8 & -47.5 & -72.3 & -4.6 & 4.5 & -27.0 & -17.6 & -63.9 \\
\hline Total ........... & -26.6 & -21.6 & -32.7 & -16.9 & -58.9 & -24.0 & -52.2 & -74.7 & -4.9 & 5.1 & -38.2 & -28.0 & -71.6 \\
\hline \multicolumn{14}{|l|}{ Middle } \\
\hline Black or African American . & -14.5 & 9.1 & -36.5 & -11.7 & -59.6 & -21.0 & -51.8 & -72.3 & -9.3 & 37.9 & -69.8 & -58.7 & -80.9 \\
\hline Hispanic white...$\ldots \ldots \ldots$ & -14.0 & 24.5 & -39.5 & -23.8 & -65.8 & -16.9 & -59.1 & -82.4 & -12.8 & 40.8 & -63.7 & -55.7 & -84.2 \\
\hline Other minority $^{3} \ldots \ldots \ldots \ldots$ & -10.5 & 16.7 & -30.1 & -19.8 & -61.2 & -25.4 & -49.1 & -78.5 & -11.3 & 35.0 & -54.8 & -49.4 & -81.5 \\
\hline Non-Hispanic white..$\ldots \ldots$ & -16.0 & -3.3 & -25.3 & -14.4 & -54.3 & -21.9 & -46.3 & -71.7 & -33.5 & 3.7 & -67.3 & -62.2 & -83.7 \\
\hline Total $\ldots \ldots \ldots \ldots$ & -17.8 & -4.1 & -29.5 & -15.5 & -58.5 & -21.5 & -50.7 & -74.9 & -26.0 & 7.3 & -64.9 & -58.3 & -82.3 \\
\hline \multicolumn{14}{|l|}{ High } \\
\hline Black or African American . & -10.5 & 19.1 & -36.3 & -21.9 & -55.3 & -16.4 & -44.7 & -70.5 & -27.6 & 13.0 & -62.0 & -57.9 & -67.9 \\
\hline Hispanic white $\ldots \ldots \ldots \ldots$. & -13.5 & 29.1 & -41.9 & -32.9 & -60.9 & -7.7 & -50.1 & -81.4 & -24.0 & 23.2 & -58.8 & -55.1 & -67.3 \\
\hline Other minority ${ }^{3} \ldots$ & -9.9 & 25.0 & -30.6 & -23.0 & -61.1 & -17.9 & -51.5 & -81.8 & -24.1 & 13.8 & -48.5 & -44.4 & -66.0 \\
\hline Non-Hispanic white...... & -6.1 & 15.0 & -18.4 & -11.3 & -47.0 & -10.1 & -35.2 & -70.0 & -27.7 & 12.1 & -49.0 & -47.7 & -55.2 \\
\hline Total $\ldots \ldots \ldots \ldots \ldots$ & -9.6 & 11.0 & -24.1 & -15.1 & -52.7 & -10.3 & -41.6 & -74.2 & -26.3 & 9.7 & -50.4 & -47.9 & -60.0 \\
\hline Missing $^{4} \ldots \ldots \ldots \ldots \ldots \ldots$ & -40.8 & -32.8 & -44.5 & -42.7 & -54.2 & -54.4 & -50.3 & -57.3 & -35.1 & .8 & -52.3 & -53.9 & -44.2 \\
\hline \multicolumn{14}{|l|}{ Census Tract of Property } \\
\hline $\begin{array}{l}\text { Income category }{ }^{6} \\
\text { Lower ...................... }\end{array}$ & & & & & & & & & & & & & \\
\hline Middle $\ldots \ldots \ldots \ldots \ldots \ldots \ldots \ldots$ & -17.9 & -7.5 & -28.9 & -15.9 & -55.1 & -21.2 & -46.7 & -73.0 & -26.4 & 8.9 & -51.7 & -49.3 & -60.9 \\
\hline High $\ldots \ldots \ldots \ldots \ldots \ldots \ldots \ldots$ & -15.4 & -1.1 & -28.8 & -17.8 & -56.8 & -17.6 & -48.3 & -77.8 & -26.3 & 8.7 & -50.7 & -48.0 & -61.0 \\
\hline Total owner occupied $\ldots \ldots \ldots$. & -18.3 & -6.8 & -28.8 & -17.3 & -56.5 & -20.6 & -48.2 & -74.4 & -26.4 & 9.0 & -51.1 & -48.5 & -60.6 \\
\hline \multicolumn{14}{|l|}{ NON-OWNER OCCUPIED ${ }^{7}$} \\
\hline Total $\ldots \ldots \ldots \ldots \ldots \ldots \ldots$ & -7.8 & 23.9 & -23.0 & -8.3 & -60.5 & -37.4 & -49.9 & -81.3 & -19.1 & 16.2 & -40.0 & -32.8 & -66.2 \\
\hline Total & -17.4 & -4.8 & -28.2 & -16.4 & -56.9 & -22.9 & -48.3 & -75.0 & -25.8 & 9.5 & -50.1 & -47.2 & -61.1 \\
\hline
\end{tabular}

Note: See notes to table 13.A.

measured by the borrower's income or the median income for the census tract, are much smaller than the differences across racial or ethnic groups. There are two notable exceptions: (1) The number of refinance loans to high-income borrowers declined less than the number to middle- or lower-income borrowers, and (2) lending to borrowers with missing income declined much more than that to borrowers whose income was reported. Loans to borrowers with nonreported income may include a disproportionate share of stated-income or no-documentation loans, two products that experienced a sharp decline in 2007.

Most of the reduction in loan volume appears to be driven by declines in the number of applications. A portion of the decline in loan originations is also accounted for by a modest increase in denial rates. The increase in the denial rate is due to a smaller reduction in the number of denials (tables 13.A and 13.B, column 2) than in the number of applications (column 1). 
The falloff in loan volumes differed substantially across loan-pricing categories. For example, the number of home-purchase loans with APR spreads of 5 percentage points or above declined almost 90 percent, whereas the number of lower-priced homepurchase loans declined only 17 percent. Differences in declines across pricing categories appear to explain at least a portion of the racial differences described earlier. For example, when comparisons are made for borrowers within each of the 12 combinations of borrower income and loan-pricing categories, the decline in home-purchase lending to blacks was lower than the decline in such lending to nonHispanic whites in 10 of the 12 cases. Thus, the much larger overall decline in lending to blacks must be driven by the fact that blacks in 2006 were disproportionately in loan-pricing categories that experienced very large rates of decline. This pattern was less evident for refinance loans: Black borrowers tended to have greater declines than non-Hispanic whites, even when the comparison was made for borrowers of the same borrower income and loan-pricing category. However, these within-category differences were much smaller than the overall racial differences between black and non-Hispanic white borrowers. Generally, the large differences in the rates of decline in lending to Hispanic whites and non-Hispanic whites persisted across the loan-pricing categories. These differences appear to have been driven primarily by geography. For example, the rate of decline in higher-priced home-purchase lending to Hispanic whites was 15 percentage points greater than the decrease in such lending to non-Hispanic whites. More than two-thirds of this difference can be attributed to differences in the distribution of Hispanic whites and non-Hispanic whites across MSAs (data not shown in tables). This finding suggests that the higher rates of decline in lending to Hispanic whites can be attributed primarily to a higher proportion of Hispanic white borrowers in MSAs where lending has declined the most.

The recent mortgage market turmoil has raised concerns about the condition of the market for loans above the conforming loan-size limit established by Fannie Mae and Freddie Mac (jumbo loans). The 2006 and 2007 HMDA data provide an opportunity to profile changes in this market segment. The number of jumbo loan originations declined from the first half of 2006 to the last half of 2007 by a larger percentage than overall lending (46 percent compared with 29 percent), and it did so for every demographic category. Further, for both lower-priced and higherpriced loan categories, declines in loan originations were greater for jumbo loans than for overall lending. The difference was particularly large for lower-priced loans. For example, jumbo lower-priced refinance loans fell by almost one-half, while overall lowerpriced refinance loans declined 16 percent.

\section{Changes in Lending by Type of Lender}

Changes in the number of loan originations differ substantially across types of lenders (tables 14.A and 14.B). For example, the number of higher-priced refinance loans originated by independent mortgage companies declined 85 percent between the first half of 2006 and the last half of 2007. In contrast, the number of such loans originated by depository institutions within their assessment areas actually rose 8 percent over the same period. ${ }^{30}$ These differences are indicative of depository institutions' larger market shares (in total lending and higher-priced lending) in their assessment areas. However, the data in these tables show that the shift in market share from independent mortgage companies to depositories in their assessment areas has had very different patterns across racial or ethnic groups. For example, depository institutions experienced an increase in their volume of lower-priced home-purchase lending to black borrowers in their assessment areas by about one-fifth for each income category. In contrast, lowerpriced home-purchase lending by depositories to nonHispanic white borrowers in their assessment areas fell for each income class. Similar differences are shown for higher-priced loans. Overall, higher-priced home-purchase lending by depository institutions in their assessment areas fell 17 percent, whereas higherpriced lending to black borrowers fell only 3 percent.

Another way of looking at differences in loan originations across types of lenders is to examine how the changes differed across geographies that were predominantly served by specific lender types in 2006 (tables 15.A and 15.B). Here we identify those census tracts where 50 percent or more of the loans in 2006 were originated by (1) independent mortgage companies, (2) depository institutions in their assessment areas, or (3) lenders that went out of business during 2007 (this group includes the 169 lenders that did not

30. Larger commercial banks and savings associations covered by the Community Reinvestment Act of 1977 (CRA)—generally those with assets of $\$ 1$ billion or more-are required to identify the census tracts in their CRA assessment areas as of the end of each calendar year. That information was used to determine which loans in the HMDA data were for properties within the lenders' CRA assessment areas. When lenders were part of a bank or thrift holding company, the combined assessment areas of all banks in the holding company were used for the analysis. 
report HMDA data for 2007 as well as those lenders that went out of business and either reported 2007 HMDA data or were merged or acquired).

Higher-priced home-purchase or refinance lending declined more than the overall market in census tracts that in 2006 were primarily served by lenders that went out of business by 2007. This was also true for census tracts that had been heavily served by independent mortgage companies. In contrast, the decline in higher-priced lending in census tracts that were primarily served by depository institutions in their assessment areas was smaller than the declines in other census tracts. Patterns for lower-priced loans are less consistent. For example, the number of lower-priced home-purchase loans in census tracts that in 2006 were primarily served by lenders that went out of business in 2007 declined less than the number of such loans extended to borrowers in other census tracts. In contrast, the number of lower-priced refinance loans in census tracts that were primarily served by lenders that went out of business in 2007 declined at a higher rate than the number of these loans in other census tracts.

Differences in the rates of decline across racial or ethnic groups for these census tracts characterized by concentrated lending are sometimes quite large. For example, higher-priced home-purchase loans to black borrowers in census tracts primarily served by lenders that went out of business declined 70 percent between the first half of 2006 and the last half of 2007. In contrast, higher-priced home-purchase loans to nonHispanic whites declined 53 percent over the same period. Interestingly, the number of lower-priced home-purchase loans to black borrowers in these census tracts increased 7 percent, while the number extended to non-Hispanic whites in the tracts decreased 3 percent.

We also look at census tracts concentrated by factors other than lender type. Specifically, we examine census tracts of two types: (1) those where 50 percent or more of the originated loans in 2006 were higher priced and (2) those where 50 percent or more of the loans were sold in the secondary market. The data indicate that the decline in the number of higherpriced loan originations in the second half of 2007 was greater in census tracts with a high concentration of sold loans in 2006 (72 percent) than in census tracts with a high concentration of higher-priced lending (57 percent). For both home-purchase and refinance loans, and for both higher-priced and lowerpriced loans, census tracts with high concentrations of sold loans showed higher-than-average declines.

\section{Changes in Lending by House Price Movements}

To investigate the potential relationship between changes in housing market conditions and changes in lending activity from 2006 to 2007, metropolitan statistical areas were grouped into two categories corresponding to the percentage changes in the House Price Index of the Office of Federal Housing Enterprise Oversight (OFHEO) from the first quarter of 2003 through the fourth quarter of 2006. ${ }^{31}$ Each of the two groups was split again according to the percentage changes in the index from the fourth quarter of 2006 through the first quarter of 2008. This process grouped census tracts in MSAs into those that, in the initial period, had either relatively weak growth or strong growth in home values and, in the more recent period, had small decreases, large decreases, or increases in home values.

As noted, the HMDA data show a marked decline in lending from 2006 to 2007 . The falloff in lending activity is related to the pattern of house price changes over the previous few years. MSAs that experienced larger declines in house prices from the fourth quarter of 2006 through the first quarter of 2008 generally experienced larger declines in loan activity than MSAs in which house prices did not fall (tables 16.A and 16.B). Furthermore, in MSAs where house prices declined, the fall in home mortgage activity was relatively greater in those MSAs that had experienced larger house price appreciation from the first quarter of 2003 through the fourth quarter of 2006. Thus, the MSAs that experienced both the sharpest declines in recent house prices and the largest increases in house prices in the preceding four years experienced the largest declines in mortgage activity. For example, the volume of lower-priced home-purchase lending for owner-occupied properties fell 53 percent in MSAs that experienced large recent declines in home values after experiencing significant run-ups in such values in the preceding four years. By comparison, areas that also had large recent declines in house prices but smaller house price appreciation before 2006 experienced a decline of lower-priced home-purchase lending for owner-occupied properties of about 5.3 percent. The severity of declines in home lending was larger for higher-priced loans than for lower-priced loans regardless of the changes in house price patterns in recent years.

\footnotetext{
31. OFHEO's House Price Index has been renamed the Federal Housing Finance Agency House Price Index. More information about the index is available at www.ofheo.gov/hpi.aspx.
} 
14. Change in the number of lower- and higher-priced loan originations, by type of lender and by characteristic of borrower and of census tract, 2006:H1 through 2007:H2

A. Home purchase

Percent

\begin{tabular}{|c|c|c|c|c|c|c|c|c|}
\hline \multirow{4}{*}{$\begin{array}{l}\text { Characteristic } \\
\text { of borrower and } \\
\text { of census tract, by } \\
\text { owner-occupancy } \\
\text { status of property }\end{array}$} & \multicolumn{4}{|c|}{ Lower-priced loans } & \multicolumn{4}{|c|}{ Higher-priced loans } \\
\hline & \multirow{3}{*}{ All } & \multicolumn{3}{|c|}{ Type of lender } & \multirow{3}{*}{ All } & \multicolumn{3}{|c|}{ Type of lender } \\
\hline & & \multicolumn{2}{|c|}{$\begin{array}{l}\text { Depository, by } \\
\text { property location }\end{array}$} & \multirow{2}{*}{$\begin{array}{l}\text { Independent } \\
\text { mortgage } \\
\text { company }\end{array}$} & & \multicolumn{2}{|c|}{$\begin{array}{l}\text { Depository, by } \\
\text { property location }\end{array}$} & \multirow{2}{*}{$\begin{array}{c}\text { Independen } \\
\text { mortgage } \\
\text { company }\end{array}$} \\
\hline & & $\begin{array}{l}\text { Within } \\
\text { assessment } \\
\text { area }^{1}\end{array}$ & $\begin{array}{c}\text { Outside of } \\
\text { assessment } \\
\text { area }\end{array}$ & & & $\begin{array}{c}\text { Within } \\
\text { assessment }^{1} \text { area }^{1}\end{array}$ & $\begin{array}{c}\text { Outside of } \\
\text { assessment } \\
\text { area }\end{array}$ & \\
\hline \multicolumn{8}{|l|}{$\begin{array}{c}\text { OWNER OCCUPIED } \\
\text { BORROWER }\end{array}$} & \\
\hline $\begin{array}{l}\text { Minority status } \\
\text { Black or African American } \ldots \\
\text { Hispanic white } \ldots \ldots \ldots \ldots \ldots \\
\text { Other minority } \ldots \ldots \ldots \ldots \ldots \\
\text { Non-Hispanic white } \ldots \ldots \ldots \ldots \ldots \\
\text { Missing } \ldots \ldots \ldots \ldots \ldots \ldots \ldots\end{array}$ & $\begin{array}{r}-2.3 \\
-26.8 \\
-15.3 \\
-14.3 \\
-9.8\end{array}$ & $\begin{array}{r}17.8 \\
-.9 \\
1.5 \\
-4.2 \\
7.0\end{array}$ & $\begin{array}{r}4.8 \\
-30.2 \\
-17.4 \\
-14.1 \\
-3.9\end{array}$ & $\begin{array}{l}-27.0 \\
-47.6 \\
-35.5 \\
-29.5 \\
-33.7\end{array}$ & $\begin{array}{l}-69.4 \\
-75.7 \\
-73.4 \\
-60.0 \\
-71.1\end{array}$ & $\begin{array}{l}-2.7 \\
-24.0 \\
-16.7 \\
-17.4 \\
-23.0\end{array}$ & $\begin{array}{l}-63.0 \\
-69.9 \\
-68.0 \\
-52.1 \\
-53.7\end{array}$ & $\begin{array}{l}-87.0 \\
-91.5 \\
-90.4 \\
-82.7 \\
-89.2\end{array}$ \\
\hline \multicolumn{9}{|l|}{$\begin{array}{l}\text { Minority status, by income } \\
\text { category }\end{array}$} \\
\hline $\begin{array}{l}\text { Lower } \\
\text { Black or African American } .\end{array}$ & 5.2 & 20.6 & 12.3 & -18.6 & -65.7 & -1.6 & -60.0 & -84.3 \\
\hline Hispanic white $\ldots \ldots \ldots \ldots$ & -4.7 & 8.2 & -11.8 & -17.5 & -60.5 & -17.2 & -55.0 & -83.6 \\
\hline Other minority $^{3} \ldots$ & -6.0 & 1.3 & -7.5 & -16.5 & -61.6 & -16.1 & -57.2 & -83.3 \\
\hline Non-Hispanic white & -11.7 & -5.1 & -11.2 & -22.9 & -54.6 & -20.5 & -47.7 & -77.9 \\
\hline \multirow{2}{*}{\multicolumn{9}{|c|}{ Middle }} \\
\hline & & & & & & & & \\
\hline Black or African American & 7.7 & 22.5 & 11.9 & -9.4 & -64.4 & 1.7 & -64.6 & -87.0 \\
\hline Hispanic white $\ldots \ldots \ldots \ldots$ & -13.1 & 9.1 & -19.1 & -27.7 & -70.3 & -13.8 & -69.9 & -90.5 \\
\hline Other minority ${ }^{3} \ldots$ & -8.8 & 5.9 & -12.4 & -22.6 & -75.1 & -16.2 & -66.2 & -87.3 \\
\hline Non-Hispanic white & -12.2 & -2.2 & -13.0 & -24.3 & -71.0 & -20.9 & -54.8 & -82.6 \\
\hline \multirow{2}{*}{\multicolumn{9}{|c|}{ High }} \\
\hline & & & & & & & & \\
\hline Black or African American & -6.9 & 17.1 & -.7 & -33.3 & -72.9 & -3.5 & -66.7 & -89.2 \\
\hline Hispanic white $\ldots \ldots \ldots \ldots$ & -35.8 & -7.1 & -37.5 & -58.2 & -81.5 & -29.5 & -77.0 & -94.0 \\
\hline Other minority $^{3} \ldots$ & -15.8 & 1.5 & -19.0 & -36.6 & -77.1 & -15.5 & -73.1 & -92.5 \\
\hline Non-Hispanic white & -13.3 & -2.7 & -13.2 & -29.9 & -61.2 & -5.7 & -53.9 & -85.0 \\
\hline & -14.6 & -1.0 & -14.8 & -33.5 & -71.3 & -12.5 & -63.8 & -89.8 \\
\hline Missing $^{4} \ldots \ldots \ldots \ldots \ldots \ldots$ & -67.7 & -40.8 & -64.9 & -86.4 & -70.3 & -48.7 & -48.8 & -91.1 \\
\hline \multicolumn{9}{|l|}{$\begin{array}{l}\text { Census TRact of Property } \\
\text { Income category }^{6}\end{array}$} \\
\hline Lower $\ldots \ldots \ldots \ldots \ldots \ldots$ & -13.2 & 6.5 & -14.3 & -35.9 & -70.0 & -14.5 & -62.3 & -88.9 \\
\hline Middle . & -13.2 & -1.0 & -11.9 & -30.7 & -65.8 & -19.2 & -57.5 & -85.8 \\
\hline High .... & -16.3 & -4.7 & -16.4 & -32.4 & -66.7 & -15.5 & -58.1 & -86.8 \\
\hline Total owner occupied & -14.4 & -1.5 & -13.9 & -32.1 & -67.1 & -17.2 & -58.8 & -86.9 \\
\hline NON-OWNER OCCUPIED ${ }^{7}$ & & & & & & & & \\
\hline Total $\ldots \ldots \ldots \ldots \ldots \ldots \ldots$ & -32.6 & -15.3 & -33.6 & -56.9 & -64.5 & -16.0 & -57.4 & -91.8 \\
\hline Total & -17.3 & -3.6 & -17.4 & -35.5 & -66.6 & -16.9 & -58.6 & -87.7 \\
\hline
\end{tabular}

NotE: Conventional first-lien mortgages for site-built properties; excludes business loans. For definitions of lower- and higher-priced lending, see text note 7 .

1. Includes lending by nonbank affiliates in the assessment areas of depository institutions covered by the Community Reinvestment Act of 1977. For more information, see text note 30 .

2. See note 4 , table 12 .
3. Other minority consists of American Indian or Alaska Native, Asian, and Native Hawaiian or other Pacific Islander.

4. Information for the characteristic was missing on the application.

5. See note 2 , table 12 .

6. See note 10 , table 12 .

7. Includes loans for which occupancy status was missing.
House price changes in the initial period affected the magnitude of changes in refinance and homepurchase markets differently. Markets that experienced strong gains in home values from 2003 to 2006 experienced smaller declines in refinance lending relative to the declines in home-purchase lending than did markets that witnessed the same recent changes in home values but weaker initial house price increases. This may be because those refinancing benefited from the earlier increase in home values and had more equity to extract or to offer as a down payment on the new loan.

Changes in Lending by the Severity of Changes in Mortgage Delinquency Rates

To investigate the potential relationship between changes in mortgage market conditions and changes 
14. Change in the number of lower- and higher-priced loan originations, by type of lender and by characteristic of borrower and of census tract, 2006:H1 through 2007:H2_Continued

B. Refinance

Percent

\begin{tabular}{|c|c|c|c|c|c|c|c|c|}
\hline \multirow{4}{*}{$\begin{array}{l}\text { Characteristic } \\
\text { of borrower and } \\
\text { of census tract, by } \\
\text { owner-occupancy } \\
\text { status of property }\end{array}$} & \multicolumn{4}{|c|}{ Lower-priced loans } & \multicolumn{4}{|c|}{ Higher-priced loans } \\
\hline & \multirow{3}{*}{ All } & \multicolumn{3}{|c|}{ Type of lender } & \multirow{3}{*}{ All } & \multicolumn{3}{|c|}{ Type of lender } \\
\hline & & \multicolumn{2}{|c|}{$\begin{array}{c}\text { Depository, by } \\
\text { property location }\end{array}$} & \multirow{2}{*}{$\begin{array}{l}\text { Independent } \\
\text { mortgage } \\
\text { company }\end{array}$} & & \multicolumn{2}{|c|}{$\begin{array}{l}\text { Depository, by } \\
\text { property location }\end{array}$} & \multirow{2}{*}{$\begin{array}{l}\text { Independent } \\
\text { mortgage } \\
\text { company }\end{array}$} \\
\hline & & $\begin{array}{l}\text { Within } \\
\text { assessment }^{\text {area }^{1}}\end{array}$ & $\begin{array}{c}\text { Outside of } \\
\text { assessment } \\
\text { area }\end{array}$ & & & $\begin{array}{l}\text { Within } \\
\text { assessment }^{1} \\
\text { area }^{1}\end{array}$ & $\begin{array}{c}\text { Outside of } \\
\text { assessment } \\
\text { area }\end{array}$ & \\
\hline \multicolumn{9}{|l|}{$\begin{array}{c}\text { OWNER OCCUPIED } \\
\text { BORROWER }\end{array}$} \\
\hline $\begin{array}{l}\text { Minority status }^{2} \\
\text { Black or African American .... } \\
\text { Hispanic white } \ldots \ldots \ldots \ldots \ldots \\
\text { Other minority }{ }^{3} \ldots \ldots \ldots \ldots \ldots \\
\text { Non-Hispanic white } \ldots \ldots \ldots \ldots \ldots \\
\text { Missing }{ }^{4} \ldots \ldots \ldots \ldots \ldots \ldots \ldots \ldots\end{array}$ & $\begin{array}{l}-16.0 \\
-28.4 \\
-22.3 \\
-15.5 \\
-16.8\end{array}$ & $\begin{array}{l}-12.5 \\
-15.6 \\
-13.6 \\
-13.2 \\
-10.6\end{array}$ & $\begin{array}{r}-5.7 \\
-17.6 \\
-16.2 \\
-8.3 \\
2.0\end{array}$ & $\begin{array}{l}-33.6 \\
-56.7 \\
-45.0 \\
-30.3 \\
-48.6\end{array}$ & $\begin{array}{l}-59.0 \\
-63.4 \\
-60.8 \\
-51.9 \\
-62.5\end{array}$ & $\begin{array}{r}-1.5 \\
18.6 \\
3.5 \\
7.2 \\
6.7\end{array}$ & $\begin{array}{l}-46.3 \\
-52.5 \\
-51.2 \\
-38.9 \\
-44.6\end{array}$ & $\begin{array}{l}-84.1 \\
-89.0 \\
-87.6 \\
-83.4 \\
-81.2\end{array}$ \\
\hline \multicolumn{9}{|l|}{$\begin{array}{l}\text { Minority status, by income } \\
\text { category } 5 \\
\text { Lower }\end{array}$} \\
\hline $\begin{array}{c}\text { Black or African American } \\
\text { Hispanic white } \ldots \ldots \ldots \ldots \ldots \\
\text { Other minority }{ }^{3} \ldots \ldots \ldots \ldots . \\
\text { Non-Hispanic white } \ldots \ldots \ldots \\
\text { Total } \ldots \ldots \ldots \ldots \ldots \ldots \ldots \\
\text { Middle }\end{array}$ & $\begin{array}{r}-9.8 \\
-14.3 \\
-13.8 \\
-18.7 \\
-16.9\end{array}$ & $\begin{array}{l}-9.6 \\
-8.2 \\
-8.7 \\
-21.0 \\
-17.9\end{array}$ & $\begin{array}{r}-2.1 \\
-1.4 \\
-10.4 \\
-11.5 \\
-7.4\end{array}$ & $\begin{array}{l}-20.6 \\
-38.5 \\
-27.9 \\
-25.7 \\
-28.9\end{array}$ & $\begin{array}{l}-61.1 \\
-66.0 \\
-60.6 \\
-54.8 \\
-58.9\end{array}$ & $\begin{array}{l}-16.4 \\
-10.8 \\
-26.7 \\
-10.5 \\
-13.5\end{array}$ & $\begin{array}{l}-49.4 \\
-53.1 \\
-48.7 \\
-42.8 \\
-45.5\end{array}$ & $\begin{array}{l}-84.5 \\
-89.9 \\
-85.8 \\
-84.2 \\
-84.2\end{array}$ \\
\hline $\begin{array}{l}\text { Middle } \\
\text { Black or African American } \\
\text { Hispanic white } \ldots \ldots \ldots \ldots \ldots \\
\text { Other minority } \\
\text { Non-Hispanic white } \ldots \ldots \ldots \ldots \\
\quad \text { Total } \ldots \ldots \ldots \ldots \ldots \ldots \ldots \\
\text { High }\end{array}$ & $\begin{array}{l}-11.7 \\
-23.8 \\
-19.8 \\
-14.4 \\
-15.5\end{array}$ & $\begin{array}{l}-10.9 \\
-16.6 \\
-18.3 \\
-14.9 \\
-15.2\end{array}$ & $\begin{array}{r}1.7 \\
-8.8 \\
-11.8 \\
-6.9 \\
-4.9\end{array}$ & $\begin{array}{l}-28.9 \\
-49.2 \\
-32.8 \\
-25.0 \\
-30.7\end{array}$ & $\begin{array}{l}-59.6 \\
-65.8 \\
-61.2 \\
-54.3 \\
-58.5\end{array}$ & $\begin{array}{r}1.6 \\
9.5 \\
-8.4 \\
.8 \\
.7\end{array}$ & $\begin{array}{l}-46.3 \\
-55.5 \\
-51.9 \\
-41.2 \\
-44.7\end{array}$ & $\begin{array}{l}-84.2 \\
-89.1 \\
-86.1 \\
-83.4 \\
-83.9\end{array}$ \\
\hline $\begin{array}{l}\text { High } \\
\text { Black or African American . } \\
\text { Hispanic white } \ldots \ldots \ldots \ldots \ldots \\
\text { Other minority } \\
\text { Non-Hispanic white } \ldots \ldots \ldots \ldots \\
\quad \text { Total } \ldots \ldots \ldots \ldots \ldots \ldots \ldots \\
\text { Missing }{ }^{4} \ldots \ldots \ldots \ldots \ldots \ldots \ldots \ldots \\
\end{array}$ & $\begin{array}{l}-21.9 \\
-32.9 \\
-23.0 \\
-11.3 \\
-15.1 \\
-42.7\end{array}$ & $\begin{array}{r}-15.3 \\
-16.3 \\
-12.5 \\
-7.0 \\
-8.5 \\
-24.1\end{array}$ & $\begin{array}{r}-12.1 \\
-24.2 \\
-16.3 \\
-2.7 \\
-5.3 \\
-38.8\end{array}$ & $\begin{array}{l}-43.0 \\
-63.7 \\
-49.8 \\
-31.2 \\
-39.3 \\
-68.3\end{array}$ & $\begin{array}{l}-55.3 \\
-60.9 \\
-61.1 \\
-47.0 \\
-52.7 \\
-54.2\end{array}$ & $\begin{array}{r}23.9 \\
52.6 \\
26.4 \\
34.6 \\
37.6 \\
-20.0\end{array}$ & $\begin{array}{l}-41.0 \\
-53.0 \\
-53.2 \\
-33.0 \\
-39.0 \\
-35.3\end{array}$ & $\begin{array}{l}-84.3 \\
-88.9 \\
-89.1 \\
-82.9 \\
-84.1 \\
-80.4\end{array}$ \\
\hline $\begin{array}{l}\text { CENSUS TRACT OF PROPERTY } \\
\text { Income category }{ }^{6}\end{array}$ & & & & & & & & \\
\hline 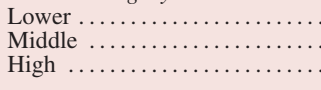 & $\begin{array}{l}-21.0 \\
-15.9 \\
-17.8\end{array}$ & $\begin{array}{l}-14.7 \\
-13.5 \\
-12.0\end{array}$ & $\begin{array}{r}-10.8 \\
-6.2 \\
-9.7\end{array}$ & $\begin{array}{l}-42.2 \\
-33.8 \\
-38.8\end{array}$ & $\begin{array}{l}-59.3 \\
-55.1 \\
-56.8\end{array}$ & $\begin{array}{r}4.7 \\
5.7 \\
14.7\end{array}$ & $\begin{array}{l}-45.9 \\
-40.9 \\
-44.4\end{array}$ & $\begin{array}{l}-85.2 \\
-83.5 \\
-83.7\end{array}$ \\
\hline Total owner occupied & -17.3 & -13.2 & -8.0 & -36.8 & -56.5 & 7.2 & -42.8 & -84.0 \\
\hline $\begin{array}{l}\text { NON-OWNER OCCUPIED }{ }^{7} \\
\text { Total } \ldots \ldots \ldots \ldots\end{array}$ & -8.3 & 7.8 & -2.2 & -46.9 & -60.5 & 17.3 & -47.0 & -92.8 \\
\hline Total . & -16.4 & -11.0 & -7.4 & -37.7 & -56.9 & 8.3 & -43.2 & -84.9 \\
\hline
\end{tabular}

NotE: See notes to table 14.A.

in lending activity from 2006 to 2007 , census tracts in MSAs were grouped into three categories according to the percentage change in their MSA-wide rate of serious mortgage delinquency from the fourth quarter of 2003 through the fourth quarter of 2007.32 This process grouped census tracts in MSAs into those that

32. Mortgage market delinquency rates by MSA were obtained from the Trend Data database; Trend Data is a registered trademark of TransUnion LLC (products.trendatatu.com/faqs.asp). Trend Data are based on the credit records of a geographically stratified random sample of about 30 million anonymous individuals drawn each quarter since 1992. The rate of serious mortgage delinquency is the percentage of outstanding mortgages that are 90 or more days delinquent or in foreclosure at the time the sample is pulled. had relatively healthy, moderate, or weak-performing mortgage markets over the past few years.

The 2006 and 2007 HMDA data show that changes in lending activity across MSAs were related not only to the magnitude and timing of changes in home prices but also to changes in mortgage performance. In particular, the falloff in loan activity was larger in MSAs that experienced the largest percentage increases in their rates of serious mortgage delinquency from the fourth quarter of 2003 through the fourth quarter of 2007 (table 17). This pattern held for both lower- and higher-priced lending and for virtually all demographic groups. For example, for lower-priced 
15. Change in the number of lower- and higher-priced loan originations, by type of loan concentration and by characteristic of borrower and of census tract, 2006:H1 through 2007:H2

A. Home purchase

Percent

\begin{tabular}{|c|c|c|c|c|c|c|c|c|c|c|c|c|}
\hline \multirow[b]{2}{*}{$\begin{array}{l}\text { Characteristic } \\
\text { of borrower and } \\
\text { of census tract, by } \\
\text { owner-occupancy } \\
\text { status of property }\end{array}$} & \multicolumn{6}{|c|}{ Lower-priced loan originations } & \multicolumn{6}{|c|}{ Higher-priced loan originations } \\
\hline & $\begin{array}{l}\text { All } \\
\text { lower- } \\
\text { priced }\end{array}$ & $\begin{array}{l}\text { Higher- } \\
\text { priced } \\
\text { loan } \\
\text { concen- } \\
\text { tration }\end{array}$ & $\begin{array}{l}\text { Sold } \\
\text { loan } \\
\text { concen- } \\
\text { tration }^{1}\end{array}$ & $\begin{array}{l}\text { Lender } \\
\text { out-of- } \\
\text { business } \\
\text { loan } \\
\text { concen- } \\
\text { tration }\end{array}$ & $\begin{array}{l}\text { Inde- } \\
\text { pendent } \\
\text { mortgage } \\
\text { company } \\
\text { loan } \\
\text { concen- } \\
\text { tration }\end{array}$ & \begin{tabular}{|c|} 
Depos- \\
itory \\
within \\
assess- \\
ment area \\
loan \\
concen- \\
tration $^{3}$
\end{tabular} & $\begin{array}{c}\text { All } \\
\text { higher- } \\
\text { priced }\end{array}$ & $\begin{array}{l}\text { Higher- } \\
\text { priced } \\
\text { loan } \\
\text { concen- } \\
\text { tration }\end{array}$ & $\begin{array}{l}\text { Sold } \\
\text { loan } \\
\text { concen- } \\
\text { tration }\end{array}$ & $\begin{array}{l}\text { Lender } \\
\text { out-of- } \\
\text { business } \\
\text { loan } \\
\text { concen- } \\
\text { tration }^{2}\end{array}$ & $\begin{array}{l}\text { Inde- } \\
\text { pendent } \\
\text { mortgage } \\
\text { company } \\
\text { loan } \\
\text { concen- } \\
\text { tration }\end{array}$ & $\begin{array}{l}\text { Depos- } \\
\text { itory } \\
\text { within } \\
\text { assess- } \\
\text { ment area } \\
\text { loan } \\
\text { concen- } \\
\text { tration }\end{array}$ \\
\hline $\begin{array}{c}\text { OWNER OCCUPIED } \\
\text { BORROWER } \\
\text { Minority status }{ }^{4}\end{array}$ & & & & & & & & & & & & \\
\hline $\begin{array}{l}\text { Black or African American .... } \\
\text { Hispanic white } \ldots \ldots \ldots \ldots \ldots \ldots \\
\text { Other minority }{ }^{5} \ldots \ldots \ldots \ldots \ldots \\
\text { Non-Hispanic white } \ldots \ldots \ldots \ldots \ldots \\
\text { Missing }\end{array}$ & $\begin{array}{r}-2.3 \\
-26.8 \\
-15.3 \\
-14.3 \\
-9.8\end{array}$ & $\begin{array}{r}-10.9 \\
-34.4 \\
-9.7 \\
-15.2 \\
-7.2\end{array}$ & $\begin{array}{l}-1.9 \\
-29.0 \\
-17.3 \\
-14.1 \\
-10.5\end{array}$ & $\begin{array}{r}6.8 \\
-27.1 \\
4.0 \\
-2.8 \\
-7.1\end{array}$ & $\begin{array}{r}-2.6 \\
-30.3 \\
-21.2 \\
-16.4 \\
-17.3\end{array}$ & $\begin{array}{r}5.1 \\
-10.8 \\
10.7 \\
-9.1 \\
-2.4\end{array}$ & $\begin{array}{l}-69.4 \\
-75.7 \\
-73.4 \\
-60.0 \\
-71.1\end{array}$ & $\begin{array}{l}-62.2 \\
-75.4 \\
-70.3 \\
-49.9 \\
-62.8\end{array}$ & $\begin{array}{l}-72.2 \\
-78.3 \\
-76.7 \\
-66.1 \\
-75.2\end{array}$ & $\begin{array}{l}-70.1 \\
-82.7 \\
-76.0 \\
-52.9 \\
-82.0\end{array}$ & $\begin{array}{l}-71.9 \\
-79.1 \\
-78.7 \\
-66.1 \\
-78.3\end{array}$ & $\begin{array}{l}-39.0 \\
-45.6 \\
-37.1 \\
-30.6 \\
-35.7\end{array}$ \\
\hline $\begin{array}{l}\text { Minority status, by income } \\
\text { category } \\
\text { Lower }\end{array}$ & & & & & & & & & & & & \\
\hline 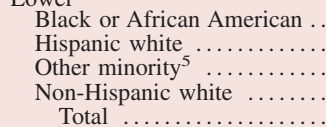 & $\begin{array}{r}5.2 \\
-4.7 \\
-6.0 \\
-11.7 \\
-9.2\end{array}$ & $\begin{array}{r}6.8 \\
-.2 \\
4.3 \\
-9.9 \\
-7.3\end{array}$ & $\begin{array}{r}6.5 \\
-5.7 \\
-5.3 \\
-10.8 \\
-7.7\end{array}$ & $\begin{array}{r}11.5 \\
-8.0 \\
24.8 \\
-9.4 \\
-5.7\end{array}$ & $\begin{array}{r}8.0 \\
2.2 \\
2.2 \\
-8.1 \\
-4.4\end{array}$ & $\begin{array}{r}9.5 \\
-8.1 \\
-10.1 \\
-9.5 \\
-9.2\end{array}$ & $\begin{array}{l}-65.7 \\
-60.5 \\
-61.6 \\
-54.6 \\
-59.2\end{array}$ & $\begin{array}{l}-44.8 \\
-42.1 \\
-54.8 \\
-34.7 \\
-38.4\end{array}$ & $\begin{array}{l}-68.5 \\
-63.8 \\
-6.8 \\
-60.6 \\
-64.4\end{array}$ & $\begin{array}{l}-67.0 \\
-66.7 \\
-56.7 \\
-44.6 \\
-61.6\end{array}$ & $\begin{array}{l}-67.3 \\
-62.2 \\
-67.5 \\
-57.4 \\
-62.9\end{array}$ & $\begin{array}{l}-37.3 \\
-41.7 \\
-34.4 \\
-33.5 \\
-35.2\end{array}$ \\
\hline Middle & & & & & & & & & & & -62.9 & -35.2 \\
\hline $\begin{array}{l}\text { Black or African American ... } \\
\text { Hispanic white } \ldots \ldots \ldots \ldots \ldots \\
\text { Other minority }{ }^{5} \ldots \ldots \ldots \ldots \ldots \\
\text { Non-Hispanic white } \ldots \ldots \ldots \ldots \\
\text { Total } \ldots \ldots \ldots \ldots \ldots \ldots \ldots \\
\text { High }\end{array}$ & $\begin{array}{r}7.7 \\
-13.1 \\
-8.8 \\
-12.2 \\
-10.1\end{array}$ & $\begin{array}{r}5.3 \\
-2.2 \\
-.8 \\
-11.8 \\
-8.9\end{array}$ & $\begin{array}{r}7.6 \\
-19.3 \\
-11.7 \\
-12.7 \\
-10.7\end{array}$ & $\begin{array}{r}7.9 \\
-6.3 \\
31.7 \\
-.2 \\
2.8\end{array}$ & $\begin{array}{r}12.1 \\
-8.9 \\
-3.2 \\
-11.4 \\
-8.0\end{array}$ & $\begin{array}{r}15.2 \\
-10.2 \\
12.6 \\
-9.0 \\
-6.4\end{array}$ & $\begin{array}{l}-64.4 \\
-70.3 \\
-75.1 \\
-71.0 \\
-67.9\end{array}$ & $\begin{array}{l}-48.8 \\
-65.7 \\
-58.3 \\
-47.8 \\
-51.9\end{array}$ & $\begin{array}{l}-73.8 \\
-78.6 \\
-74.5 \\
-68.7 \\
-73.4\end{array}$ & $\begin{array}{l}-69.4 \\
-83.7 \\
-69.4 \\
-51.5 \\
-72.9\end{array}$ & $\begin{array}{l}-71.4 \\
-76.7 \\
-756.3 \\
-66.6 \\
-72.4\end{array}$ & $\begin{array}{l}-24.2 \\
-43.5 \\
-38.8 \\
-32.6 \\
-34.5\end{array}$ \\
\hline 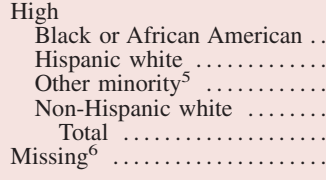 & $\begin{array}{r}-6.9 \\
-35.8 \\
-15.8 \\
-13.3 \\
-14.6 \\
-67.7\end{array}$ & $\begin{array}{l}-17.8 \\
-42.3 \\
-10.4 \\
-15.1 \\
-15.2 \\
-59.3\end{array}$ & $\begin{array}{r}-6.8 \\
-38.2 \\
-19.3 \\
-12.8 \\
-16.0 \\
-73.4\end{array}$ & $\begin{array}{r}9.7 \\
-36.0 \\
-4.0 \\
1.4 \\
-62 \\
-62.0\end{array}$ & $\begin{array}{l}-10.9 \\
-42.1 \\
-25.4 \\
-17.6 \\
-22.1 \\
-75.8\end{array}$ & $\begin{array}{r}.4 \\
-10.7 \\
15.0 \\
-7.6 \\
-3.6 \\
-41.5\end{array}$ & $\begin{array}{l}-72.9 \\
-81.5 \\
-77.1 \\
-61.2 \\
-71.3 \\
-70.3\end{array}$ & $\begin{array}{l}-70.7 \\
-80.3 \\
-72.9 \\
-54.5 \\
-65.2 \\
-59.8\end{array}$ & $\begin{array}{l}-75.4 \\
-83.5 \\
-81.0 \\
-68.1 \\
-76.9 \\
-72.6\end{array}$ & $\begin{array}{l}-75.2 \\
-86.6 \\
-79.6 \\
-59.1 \\
-79.9 \\
-60.6\end{array}$ & $\begin{array}{l}-76.4 \\
-84.5 \\
-81.5 \\
-69.4 \\
-78.8 \\
-73.3\end{array}$ & $\begin{array}{l}-50.6 \\
-51.1 \\
-35.6 \\
-24.9 \\
-29.8 \\
-51.7\end{array}$ \\
\hline $\begin{array}{l}\text { CENSUS TRACT OF PROPERTY } \\
\text { Income category } \\
\end{array}$ & & & & & & & & & & & & \\
\hline $\begin{array}{l}\text { Lower } \ldots \ldots \ldots \ldots \ldots \ldots \ldots \ldots \\
\text { Middle } \ldots \ldots \ldots \ldots \ldots \ldots \ldots \ldots \ldots \ldots \ldots \ldots \ldots \ldots \\
\text { High } \ldots \ldots \ldots \ldots \ldots \ldots \ldots \ldots \ldots\end{array}$ & $\begin{array}{l}-13.2 \\
-13.2 \\
-16.3\end{array}$ & $\begin{array}{r}-9.3 \\
-12.7 \\
-16.3\end{array}$ & $\begin{array}{l}-14.8 \\
-14.7 \\
-14.8\end{array}$ & $\begin{array}{r}-2.5 \\
-6.3 \\
-11.2\end{array}$ & $\begin{array}{l}-17.6 \\
-17.0 \\
-20.0\end{array}$ & $\begin{array}{l}-3.4 \\
-3.1 \\
-9.3\end{array}$ & $\begin{array}{l}-70.0 \\
-65.8 \\
-66.7\end{array}$ & $\begin{array}{l}-60.0 \\
-56.5 \\
-61.0\end{array}$ & $\begin{array}{l}-73.8 \\
-71.6 \\
-71.3\end{array}$ & $\begin{array}{l}-77.0 \\
-68.5 \\
-73.2\end{array}$ & $\begin{array}{l}-76.2 \\
-73.0 \\
-71.6\end{array}$ & $\begin{array}{l}-38.3 \\
-31.2 \\
-34.7\end{array}$ \\
\hline Total owner occupied $\ldots \ldots \ldots$. & -14.4 & -14.7 & -14.8 & -6.4 & -18.2 & -6.2 & -67.1 & -59.1 & -72.3 & -73.8 & -73.8 & -33.6 \\
\hline NON-OWNER OCCUPIED ${ }^{9}$ & & & & & & & & & & & & \\
\hline Total $\ldots \ldots \ldots \ldots \ldots \ldots \ldots$ & -32.6 & -23.8 & -39.5 & -16.6 & -40.4 & -13.8 & -64.5 & -45.9 & -69.6 & -66.7 & -69.9 & -40.6 \\
\hline Total . & -17.3 & -16.0 & -18.8 & -7.9 & -21.7 & -7.3 & -66.6 & -57.0 & -71.7 & -72.6 & -73.1 & -35.1 \\
\hline
\end{tabular}

Note: See general note to table 14.A. Loan concentration is by census tract. Lending in a census tract is defined as concentrated if 50 percent or more of the loans originated in the tract in 2006 had a particular characteristic or if 50 percent or more of the loans originated in the tract in that year were originated by a particular type of lender.

1. Sold loans are loans sold by the originator within the calendar year of origination.

2. Lenders that went out of business consist of lenders that ceased operations during 2007 (this group includes the 169 lenders that did not report data for 2007 under the Home Mortgage Disclosure Act as well as those lenders that went out of business and either reported 2007 HMDA data or were merged or acquired).

home-purchase loans, the decline in lending in MSAs experiencing smaller increases in delinquency rates was about one-half of that in MSAs experiencing very significant changes in delinquency rates. The decline in lending was particularly severe for higherpriced loans in MSAs with very significant increases

3. For explanation of lending within assessment area, see note 1, table 14.A. 4. See note 4 , table 12 .

5. Other minority consists of American Indian or Alaska Native, Asian, and Native Hawaiian or other Pacific Islander.

6. Information for the characteristic was missing on the application.

7. See note 2 , table 12 .

8. See note 10 , table 12

9. See note 7 , table 12 .

in delinquency rates: Lending of such loans fell more than 81 percent from 2006 to 2007 . The relationship between the decline in lending activity and the severity of changes in mortgage delinquency was similar for refinancings, although the falloff in activity was more muted. 
15. Change in the number of lower- and higher-priced loan originations, by type of loan concentration and by characteristic of borrower and of census tract, 2006:H1 through 2007:H2-Continued

B. Refinance

Percent

\begin{tabular}{|c|c|c|c|c|c|c|c|c|c|c|c|c|}
\hline \multirow[b]{2}{*}{$\begin{array}{l}\text { Characteristic } \\
\text { of borrower and } \\
\text { of census tract, by } \\
\text { owner-occupancy } \\
\text { status of property }\end{array}$} & \multicolumn{6}{|c|}{ Lower-priced loan originations } & \multicolumn{6}{|c|}{ Higher-priced loan originations } \\
\hline & $\begin{array}{l}\text { All } \\
\text { lower- } \\
\text { priced }\end{array}$ & $\begin{array}{l}\text { Higher- } \\
\text { priced } \\
\text { loan } \\
\text { concen- } \\
\text { tration }\end{array}$ & $\begin{array}{l}\text { Sold } \\
\text { loan } \\
\text { concen- } \\
\text { tration }^{1}\end{array}$ & $\begin{array}{l}\text { Lender } \\
\text { out-of- } \\
\text { business } \\
\text { loan } \\
\text { concen- } \\
\text { tration }^{2}\end{array}$ & $\begin{array}{l}\text { Inde- } \\
\text { pendent } \\
\text { mortgage } \\
\text { company } \\
\text { loan } \\
\text { concen- } \\
\text { tration }\end{array}$ & $\begin{array}{c}\text { Depos- } \\
\text { itory } \\
\text { within } \\
\text { assess- } \\
\text { ment area } \\
\text { loan } \\
\text { concen- } \\
\text { tration }^{3}\end{array}$ & $\begin{array}{c}\text { All } \\
\text { higher- } \\
\text { priced }\end{array}$ & $\begin{array}{l}\text { Higher- } \\
\text { priced } \\
\text { loan } \\
\text { concen- } \\
\text { tration }\end{array}$ & $\begin{array}{l}\text { Sold } \\
\text { loan } \\
\text { concen- } \\
\text { tration }^{1}\end{array}$ & $\begin{array}{l}\text { Lender } \\
\text { out-of- } \\
\text { business } \\
\text { loan } \\
\text { concen- } \\
\text { tration }^{2}\end{array}$ & $\begin{array}{c}\text { Inde- } \\
\text { pendent } \\
\text { mortgage } \\
\text { company } \\
\text { loan } \\
\text { concen- } \\
\text { tration }\end{array}$ & \begin{tabular}{|c|} 
Depos- \\
itory \\
within \\
assess- \\
ment area \\
loan \\
concen- \\
tration $^{3}$
\end{tabular} \\
\hline $\begin{array}{l}\text { OWNER OCCUPIED } \\
\text { BORROWER } \\
\text { Minority status }^{4}\end{array}$ & & & & & & & & & & & & \\
\hline $\begin{array}{l}\text { Black or African American } \ldots \\
\text { Hispanic white } \ldots \ldots \ldots \ldots \ldots \\
\text { Other minority }{ }^{5} \ldots \ldots \ldots \ldots \\
\text { Non-Hispanic white } \ldots \ldots \ldots \ldots \\
\text { Missing }^{6} \ldots \ldots \ldots \ldots \ldots \ldots\end{array}$ & $\begin{array}{l}-16.0 \\
-28.4 \\
-22.3 \\
-15.5 \\
-16.8\end{array}$ & $\begin{array}{l}-32.0 \\
-40.2 \\
-20.1 \\
-21.8 \\
-20.1\end{array}$ & $\begin{array}{l}-15.7 \\
-27.0 \\
-25.9 \\
-17.7 \\
-19.0\end{array}$ & $\begin{array}{l}-30.6 \\
-35.9 \\
-27.3 \\
-19.8 \\
-29.7\end{array}$ & $\begin{array}{l}-27.5 \\
-34.5 \\
-34.9 \\
-26.3 \\
-28.7\end{array}$ & $\begin{array}{r}-3.5 \\
-20.2 \\
7.2 \\
-9.0 \\
-10.3\end{array}$ & $\begin{array}{l}-59.0 \\
-63.4 \\
-60.8 \\
-51.9 \\
-62.5\end{array}$ & $\begin{array}{l}-43.7 \\
-55.3 \\
-51.2 \\
-39.9 \\
-48.0\end{array}$ & $\begin{array}{l}-63.4 \\
-66.2 \\
-65.8 \\
-59.9 \\
-66.9\end{array}$ & $\begin{array}{l}-61.0 \\
-64.2 \\
-60.4 \\
-50.8 \\
-64.0\end{array}$ & $\begin{array}{l}-65.1 \\
-66.4 \\
-68.4 \\
-62.3 \\
-66.8\end{array}$ & $\begin{array}{l}-12.7 \\
-32.6 \\
-31.2 \\
-15.8 \\
-30.2\end{array}$ \\
\hline \multicolumn{13}{|l|}{$\begin{array}{l}\text { Minority status, by income } \\
\text { category }\end{array}$} \\
\hline $\begin{array}{l}\text { Black or African American } . . \\
\text { Hispanic white } \ldots \ldots \ldots \ldots \ldots \\
\text { Other minority }{ }^{5} \ldots \ldots \ldots \ldots \\
\text { Non-Hispanic white } \ldots \ldots \ldots \\
\text { Total } \ldots \ldots \ldots \ldots \ldots \ldots\end{array}$ & $\begin{array}{l}-9.8 \\
-14.3 \\
-13.8 \\
-18.7 \\
-16.9\end{array}$ & $\begin{array}{r}-18.9 \\
-20.8 \\
3.5 \\
-21.5 \\
-19.7\end{array}$ & $\begin{array}{l}-10.1 \\
-16.3 \\
-20.5 \\
-20.5 \\
-18.1\end{array}$ & $\begin{array}{l}-22.5 \\
-23.0 \\
-26.2 \\
-18.4 \\
-22.2\end{array}$ & $\begin{array}{r}-4.9 \\
-8.1 \\
-11.4 \\
-8.6 \\
-23.1\end{array}$ & $\begin{array}{r}-6.5 \\
-12.9 \\
59.9 \\
-13.9 \\
-11.4\end{array}$ & $\begin{array}{l}-61.1 \\
-66.0 \\
-60.6 \\
-54.8 \\
-58.9\end{array}$ & $\begin{array}{l}-31.4 \\
-45.2 \\
-46.0 \\
-37.0 \\
-39.6\end{array}$ & $\begin{array}{l}-65.8 \\
-69.0 \\
-65.3 \\
-62.0 \\
-64.9\end{array}$ & $\begin{array}{l}-60.9 \\
-68.7 \\
-50.9 \\
-51.9 \\
-61.3\end{array}$ & $\begin{array}{l}-67.3 \\
-69.5 \\
-67.1 \\
-63.5 \\
-66.8\end{array}$ & $\begin{array}{l}-19.1 \\
-41.0 \\
-50.5 \\
-22.0 \\
-25.4\end{array}$ \\
\hline $\begin{array}{l}\text { Middle } \\
\text { Black or African American } . \\
\text { Hispanic white } \ldots \ldots \ldots \ldots \ldots \\
\text { Other minority }{ }^{5} \ldots \ldots \ldots \ldots \\
\text { Non-Hispanic white } \ldots \ldots \ldots \\
\quad \text { Total } \ldots \ldots \ldots \ldots \ldots \ldots \ldots \\
\text { High }\end{array}$ & $\begin{array}{l}-11.7 \\
-23.8 \\
-19.8 \\
-14.4 \\
-15.5\end{array}$ & $\begin{array}{l}-24.9 \\
-31.7 \\
-21.8 \\
-20.1 \\
-21.2\end{array}$ & $\begin{array}{l}-12.7 \\
-24.9 \\
-21.5 \\
-17.0 \\
-17.8\end{array}$ & $\begin{array}{l}-32.1 \\
-34.2 \\
-22.5 \\
-19.6 \\
-26.7\end{array}$ & $\begin{array}{r}4.9 \\
7.7 \\
-3.9 \\
-4 \\
-26.0\end{array}$ & $\begin{array}{r}3.0 \\
-21.8 \\
-6.3 \\
-6.9 \\
-7.4\end{array}$ & $\begin{array}{l}-59.6 \\
-65.8 \\
-61.2 \\
-54.3 \\
-58.5\end{array}$ & $\begin{array}{l}-45.2 \\
-57.6 \\
-56.1 \\
-44.5 \\
-48.1\end{array}$ & $\begin{array}{l}-64.0 \\
-69.2 \\
-65.8 \\
-61.0 \\
-64.4\end{array}$ & $\begin{array}{l}-64.8 \\
-63.4 \\
-60.5 \\
-54.6 \\
-62.5\end{array}$ & $\begin{array}{l}-65.9 \\
-68.5 \\
-67.9 \\
-64.6 \\
-66.6\end{array}$ & $\begin{array}{l}-2.4 \\
-26.2 \\
-39.7 \\
-22.3 \\
-21.8\end{array}$ \\
\hline $\begin{array}{l}\text { Black or African American } . \\
\text { Hispanic white } \ldots \ldots \ldots \ldots \ldots \\
\text { Other minority }{ }^{5} \ldots \ldots \ldots \ldots \\
\text { Non-Hispanic white } \ldots \ldots \ldots \\
\text { Total } \ldots \ldots \ldots \ldots \ldots \ldots \ldots \ldots \\
\text { Missing }^{6} \ldots \ldots \ldots \ldots \ldots \ldots \ldots\end{array}$ & $\begin{array}{l}-21.9 \\
-32.9 \\
-23.0 \\
-11.3 \\
-15.1 \\
-42.7\end{array}$ & $\begin{array}{l}-37.3 \\
-43.8 \\
-20.4 \\
-20.2 \\
-22.0 \\
-46.7\end{array}$ & $\begin{array}{l}-21.4 \\
-29.0 \\
-27.0 \\
-12.1 \\
-16.8 \\
-45.3\end{array}$ & $\begin{array}{l}-34.6 \\
-38.3 \\
-25.8 \\
-17.2 \\
-25.8 \\
-51.2\end{array}$ & $\begin{array}{r}19.5 \\
38.2 \\
31.5 \\
18.8 \\
-29.8 \\
-50.8\end{array}$ & $\begin{array}{r}1.8 \\
-16.4 \\
6.7 \\
-5.3 \\
-4.7 \\
-39.5\end{array}$ & $\begin{array}{l}-55.3 \\
-60.9 \\
-61.1 \\
-47.0 \\
-52.7 \\
-54.2\end{array}$ & $\begin{array}{l}-50.7 \\
-56.8 \\
-51.2 \\
-39.2 \\
-43.5 \\
-36.7\end{array}$ & $\begin{array}{l}-59.5 \\
-63.2 \\
-66.5 \\
-56.3 \\
-60.0 \\
-56.7\end{array}$ & $\begin{array}{l}-58.1 \\
-62.5 \\
-63.7 \\
-48.4 \\
-57.4 \\
-39.0\end{array}$ & $\begin{array}{l}-62.6 \\
-64.4 \\
-69.3 \\
-60.0 \\
-62.5 \\
-54.6\end{array}$ & $\begin{array}{r}-8.5 \\
-29.1 \\
-20.0 \\
-6.4 \\
-11.1 \\
-13.6\end{array}$ \\
\hline 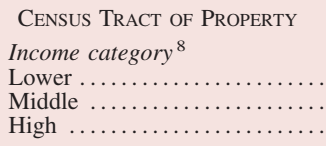 & $\begin{array}{l}-21.0 \\
-15.9 \\
-17.8\end{array}$ & $\begin{array}{l}-28.8 \\
-23.6 \\
-21.7\end{array}$ & $\begin{array}{l}-22.1 \\
-18.5 \\
-18.3\end{array}$ & $\begin{array}{l}-31.4 \\
-24.9 \\
-21.5\end{array}$ & $\begin{array}{l}-30.7 \\
-28.0 \\
-28.7\end{array}$ & $\begin{array}{r}-11.4 \\
-2.3 \\
-12.2\end{array}$ & $\begin{array}{l}-59.3 \\
-55.1 \\
-56.8\end{array}$ & $\begin{array}{l}-37.7 \\
-40.9 \\
-47.6\end{array}$ & $\begin{array}{l}-63.8 \\
-62.5 \\
-63.2\end{array}$ & $\begin{array}{l}-62.7 \\
-54.9 \\
-57.9\end{array}$ & $\begin{array}{l}-66.0 \\
-64.2 \\
-63.8\end{array}$ & $\begin{array}{l}-19.8 \\
-17.2 \\
-22.4\end{array}$ \\
\hline Total owner occupied $\ldots \ldots \ldots$. & -17.3 & -22.9 & -19.3 & -26.9 & -28.8 & -8.3 & -56.5 & -43.6 & -63.0 & -59.6 & -64.7 & -18.8 \\
\hline NON-OWNER OCCUPIED ${ }^{9}$ & & & & & & & & & & & & \\
\hline Total $\ldots \ldots \ldots \ldots \ldots \ldots \ldots$ & -8.3 & -11.7 & -10.2 & -12.2 & 19.8 & 3.5 & -60.5 & -48.7 & -65.8 & -67.3 & -68.7 & -29.4 \\
\hline Total & -16.4 & -21.8 & -18.3 & -25.2 & -27.4 & -6.9 & -56.9 & -44.1 & -63.3 & -60.7 & -65.2 & -19.9 \\
\hline
\end{tabular}

Note: See notes to table 15.A.

\section{DIFFERENCES IN LENDING OUTCOMES BY RACE, ETHNICITY, OR SEX OF THE BORROWER}

The HMDA data allow comparisons of the outcomes of the lending process across borrowers grouped by their race, ethnicity, or sex. Three outcomes are considered here: (1) the incidence of higher-priced lending, (2) the mean APR spreads paid by borrowers with higher-priced loans, and (3) denial rates. Analyses of HMDA data from earlier years revealed substantial differences in the incidence of higher-priced lending and in denial rates across racial and ethnic lines; analyses further showed that such differences could not be fully explained by factors included in the HMDA data. ${ }^{33}$ Studies also found that differences across groups in mean APR spreads paid by those with higher-priced loans were generally small.

The analysis here uses the 2007 HMDA data to examine these three lending outcomes across racial, ethnic, and gender groups. The analysis focuses on conventional first-lien home-purchase and refinance

33. See Avery, Brevoort, and Canner, "The 2006 HMDA Data" and "Higher-Priced Home Lending and the 2005 HMDA Data"; see also Avery, Canner, and Cook, "New Information Reported under HMDA." 
16. Change in the number of lower- and higher-priced loan originations, by recent change in house price index in metropolitan statistical area and by characteristic of borrower and of census tract, 2006:H1 through 2007:H2

A. Home purchase

Percent

\begin{tabular}{|c|c|c|c|c|c|c|c|c|c|c|c|c|c|c|}
\hline \multirow{5}{*}{$\begin{array}{l}\text { Characteristic } \\
\text { of borrower and } \\
\text { of census tract, by } \\
\text { owner-occupancy } \\
\text { status of property }\end{array}$} & \multicolumn{7}{|c|}{ Lower priced } & \multicolumn{7}{|c|}{ Higher priced } \\
\hline & \multirow{4}{*}{$\begin{array}{l}\text { Loans } \\
\text { to all } \\
\text { MSAs }\end{array}$} & \multicolumn{6}{|c|}{$\begin{array}{l}\text { Change in house price index in MSA, } \\
\text { 2006:Q4 to 2008:Q1 (percent) }\end{array}$} & \multirow{4}{*}{$\begin{array}{l}\text { Loans } \\
\text { to all } \\
\text { MSAs }\end{array}$} & \multicolumn{6}{|c|}{$\begin{array}{l}\text { Change in house price index in MSA, } \\
\text { 2006:Q4 to 2008:Q1 (percent) }\end{array}$} \\
\hline & & \multicolumn{2}{|c|}{\begin{tabular}{|c|}
$\begin{array}{c}\text { Large decrease } \\
(-8 \text { or less })\end{array}$ \\
\end{tabular}} & \multicolumn{2}{|c|}{$\begin{array}{l}\text { Small decrease } \\
(-8-0)\end{array}$} & \multicolumn{2}{|c|}{$\begin{array}{c}\text { Increase } \\
(0 \text { or more })\end{array}$} & & \multicolumn{2}{|c|}{$\begin{array}{l}\text { Large decrease } \\
\text { (-8 or less) }\end{array}$} & \multicolumn{2}{|c|}{$\begin{array}{c}\text { Small decrease } \\
(-8-0)\end{array}$} & \multicolumn{2}{|c|}{\begin{tabular}{|c} 
Increase \\
$(0$ or more $)$
\end{tabular}} \\
\hline & & \multicolumn{6}{|c|}{$\begin{array}{l}\text { Change in house price index in MSA, } \\
\text { 2003:Q1 to 2006:Q4 (percent) }\end{array}$} & & \multicolumn{6}{|c|}{$\begin{array}{c}\text { Change in house price index in MSA, } \\
\text { 2003:Q1 to 2006:Q4 (percent) }\end{array}$} \\
\hline & & \begin{tabular}{|c|} 
Small \\
increase \\
(less \\
than 30)
\end{tabular} & \begin{tabular}{|c|} 
Large \\
increase \\
$(30$ or \\
more $)$ \\
\end{tabular} & $\begin{array}{c}\text { Small } \\
\text { increase } \\
\text { (less } \\
\text { than 30) }\end{array}$ & \begin{tabular}{|c} 
Large \\
increase \\
(30 or \\
more)
\end{tabular} & $\begin{array}{c}\text { Small } \\
\text { increase } \\
\text { (less } \\
\text { than 30) }\end{array}$ & \begin{tabular}{|c|} 
Large \\
increase \\
$(30$ or \\
more $)$ \\
\end{tabular} & & \begin{tabular}{|c|} 
Small \\
increase \\
(less \\
than 30)
\end{tabular} & \begin{tabular}{|c} 
Large \\
increase \\
(30 or \\
more)
\end{tabular} & $\begin{array}{c}\text { Small } \\
\text { increase } \\
\text { (less } \\
\text { than 30) }\end{array}$ & \begin{tabular}{|c|} 
Large \\
increase \\
$(30$ or \\
more $)$
\end{tabular} & $\begin{array}{c}\text { Small } \\
\text { increase } \\
\text { (less } \\
\text { than 30) }\end{array}$ & \begin{tabular}{|c} 
Large \\
increase \\
(30 or \\
more)
\end{tabular} \\
\hline \multicolumn{15}{|l|}{$\begin{array}{c}\text { OWNER OCCUPIED } \\
\text { BORROWER }\end{array}$} \\
\hline $\begin{array}{l}\text { Black or African American } \\
\text { Hispanic white } \ldots \ldots \ldots \ldots \\
\text { Other minority }{ }^{2} \ldots \ldots \ldots \ldots \\
\text { Non-Hispanic white } \ldots \ldots \ldots \\
\text { Missing }{ }^{3} \ldots \ldots \ldots \ldots \ldots \ldots\end{array}$ & $\begin{array}{r}-2.9 \\
-27.7 \\
-15.9 \\
-15.6 \\
-10.2\end{array}$ & $\begin{array}{l}-8.5 \\
-20.7 \\
-12.1 \\
-15.4 \\
-14.0\end{array}$ & $\begin{array}{l}-21.7 \\
-45.4 \\
-31.3 \\
-29.1 \\
-31.7\end{array}$ & $\begin{array}{r}1.6 \\
-5.8 \\
-4.8 \\
-11.7 \\
-5.4\end{array}$ & $\begin{array}{r}-3.6 \\
-30.6 \\
-12.9 \\
-18.8 \\
-11.3\end{array}$ & $\begin{array}{r}.8 \\
-4.5 \\
-8.0 \\
-81.0 \\
1.5\end{array}$ & $\begin{array}{r}2.8 \\
-1.2 \\
-8.1 \\
-10.1 \\
6.5\end{array}$ & $\begin{array}{l}-69.9 \\
-76.3 \\
-74.5 \\
-62.7 \\
-72.6\end{array}$ & $\begin{array}{l}-57.9 \\
-60.2 \\
-57.4 \\
-46.7 \\
-76.5\end{array}$ & $\begin{array}{l}-81.2 \\
-85.6 \\
-83.5 \\
-76.9 \\
-83.6\end{array}$ & $\begin{array}{l}-68.8 \\
-60.8 \\
-66.5 \\
-57.4 \\
-70.1\end{array}$ & $\begin{array}{l}-71.9 \\
-77.3 \\
-74.4 \\
-68.2 \\
-73.5\end{array}$ & $\begin{array}{l}-67.5 \\
-56.8 \\
-60.1 \\
-55.3 \\
-62.6\end{array}$ & $\begin{array}{l}-61.2 \\
-58.8 \\
-58.9 \\
-57.0 \\
-60.1\end{array}$ \\
\hline \multicolumn{15}{|l|}{$\begin{array}{l}\text { Minority status, by income } \\
\text { category }{ }^{4}\end{array}$} \\
\hline Black or African American & 5.1 & -15.3 & 20.9 & -1.2 & 13.7 & 2.5 & -.2 & -66.0 & -58.8 & -69.7 & -65.8 & -67.0 & -68.2 & -60.3 \\
\hline & -4.5 & -27.4 & 21.5 & -9.9 & & -7.3 & -3.9 & & & & & & & \\
\hline & -6.1 & -18.4 & 43.3 & -2.8 & -3.0 & -19.1 & -10 & & & & & & & -58 \\
\hline Non-Hi & -12.5 & -14 & 6.9 & -13.6 & -13.2 & -14.1 & -10 & & & & & & & -57.2 \\
\hline Total & -9.6 & -15 . & 12.1 & -12 & -8.7 & -11.6 & & -60 & & -66.2 & & -66.4 & -59.6 & -57.8 \\
\hline \multicolumn{15}{|l|}{ Middle } \\
\hline Black or Afric & 7.2 & 6. & 18.6 & 5.5 & 2.9 & 10.2 & 7.5 & -71.0 & -57.7 & -79.9 & -72.1 & -72.6 & -69.9 & -63.9 \\
\hline & -14.0 & -12 . & -3.6 & -7.1 & -26 . & -2.1 & & & & & & & & \\
\hline & -9.6 & -13.0 & 11. & -7.8 & -13 & -14.4 & -8.2 & & & -7 & & & & \\
\hline Non-H & -13 . & -17.1 & -7 . & -13 & -17 & -12.1 & & & & -73.8 & & & & -61 \\
\hline \multirow{2}{*}{\multicolumn{15}{|c|}{ High }} \\
\hline & & & & & & & & & & & & & & \\
\hline & -36.9 & -11.5 & -54.6 & 8.1 & $\begin{array}{l}-10.1 \\
-34.1\end{array}$ & 12.1 & 7. & -8 & -48 & -8 & $\begin{array}{l}-1 \\
-5\end{array}$ & & -51 & -58 \\
\hline Other & & -3.8 & -36.5 & & -10.2 & 6.4 & -2.9 & $-7 \varepsilon$ & -60.8 & -84.5 & -62.8 & -7. & -51.2 & -59 \\
\hline Non-His & -14.8 & -13.2 & -33.5 & -5.9 & & -5.1 & -7.2 & & & & -56.6 & & -49.8 & -50.7 \\
\hline Total & -16.0 & -10.4 & -38.0 & -3.4 & -17.2 & -1.8 & -3.9 & -73 & -58.1 & -84.5 & -59.8 & -73.4 & -54.1 & -53.6 \\
\hline Missing $^{3}$ & -68.5 & -50.6 & -79.7 & -58.3 & -70.6 & -61.6 & -56.9 & -70.6 & -66.7 & -77.5 & -60.8 & -72.2 & -65.3 & -65.2 \\
\hline \multicolumn{15}{|l|}{$\begin{array}{l}\text { CENSUS TRACT OF PROPERTY } \\
\text { Income category } 5\end{array}$} \\
\hline Lower $\ldots \ldots \ldots \ldots \ldots \ldots \ldots$ & -14.0 & -30.2 & -32.4 & -11.7 & -14.8 & -2.8 & -3.2 & -70.9 & -62.2 & -84.9 & -64.6 & -73.5 & -58.5 & -58.3 \\
\hline & -16 & -15.4 & -33.1 & 06 & -19.1 & -6.5 & & & & -82.5 & -60.6 & -72.7 & -58.9 & -58.5 \\
\hline & & & & & & & & & & & & & -61.8 & \\
\hline Total owner occupied...$\ldots$. & -36.1 & -5.3 & -52.9 & -15.4 & -41.0 & -19.0 & -28.8 & -66.3 & -61.1 & -80.2 & -58.6 & -69.6 & -56.3 & -59.5 \\
\hline \multicolumn{15}{|l|}{ NON-OWNER OCCUPIED ${ }^{6}$} \\
\hline Total $\ldots \ldots \ldots \ldots \ldots \ldots \ldots$ & -15.5 & -14.6 & -32.6 & -10.0 & -17.8 & -8.6 & -7.4 & -69.1 & -55.1 & -82.4 & -61.5 & -72.4 & -59.6 & -58.4 \\
\hline Total . & -18.5 & -14.0 & -37.1 & -10.5 & -21.5 & -9.8 & -10.8 & -68.5 & -56.6 & -82.0 & -60.9 & -71.9 & -59.0 & -58.6 \\
\hline
\end{tabular}

Note: See general note to table 14.A

1. See note 4 , table 12 .

2. Other minority consists of American Indian or Alaska Native, Asian, and Native Hawaiian or other Pacific Islander.

3. Information for the characteristic was missing on the application.

4. See note 2 , table 12 .

5. See note 10 , table 12 .

6. Includes loans for which occupancy status was missing.

MSA Metropolitan statistical area.

Source: For house price index, Office of Federal Housing Enterprise Oversight (www.ofheo.gov/hpi.aspx).

loans for owner-occupied, one- to four-family, sitebuilt homes, as these are the loan product categories included in the HMDA data with the largest number of reported loans.

Although the HMDA data include a variety of detailed information about mortgage transactions, many key factors that are considered by lenders in credit underwriting and pricing are not included.
However, analysis using the HMDA data can account for some factors likely related to the lending process. Specifically, the HMDA data allow an accounting for property location (for example, the same metropolitan area), income relied on in underwriting, loan amount, time of year when the loan was made, and the presence of a co-applicant. To the extent that some of these HMDA factors are not used directly in 
16. Change in the number of lower- and higher-priced loan originations, by recent change in house price index in metropolitan statistical area and by characteristic of borrower and of census tract, 2006:H1 through 2007:H2Continued

B. Refinance

Percent

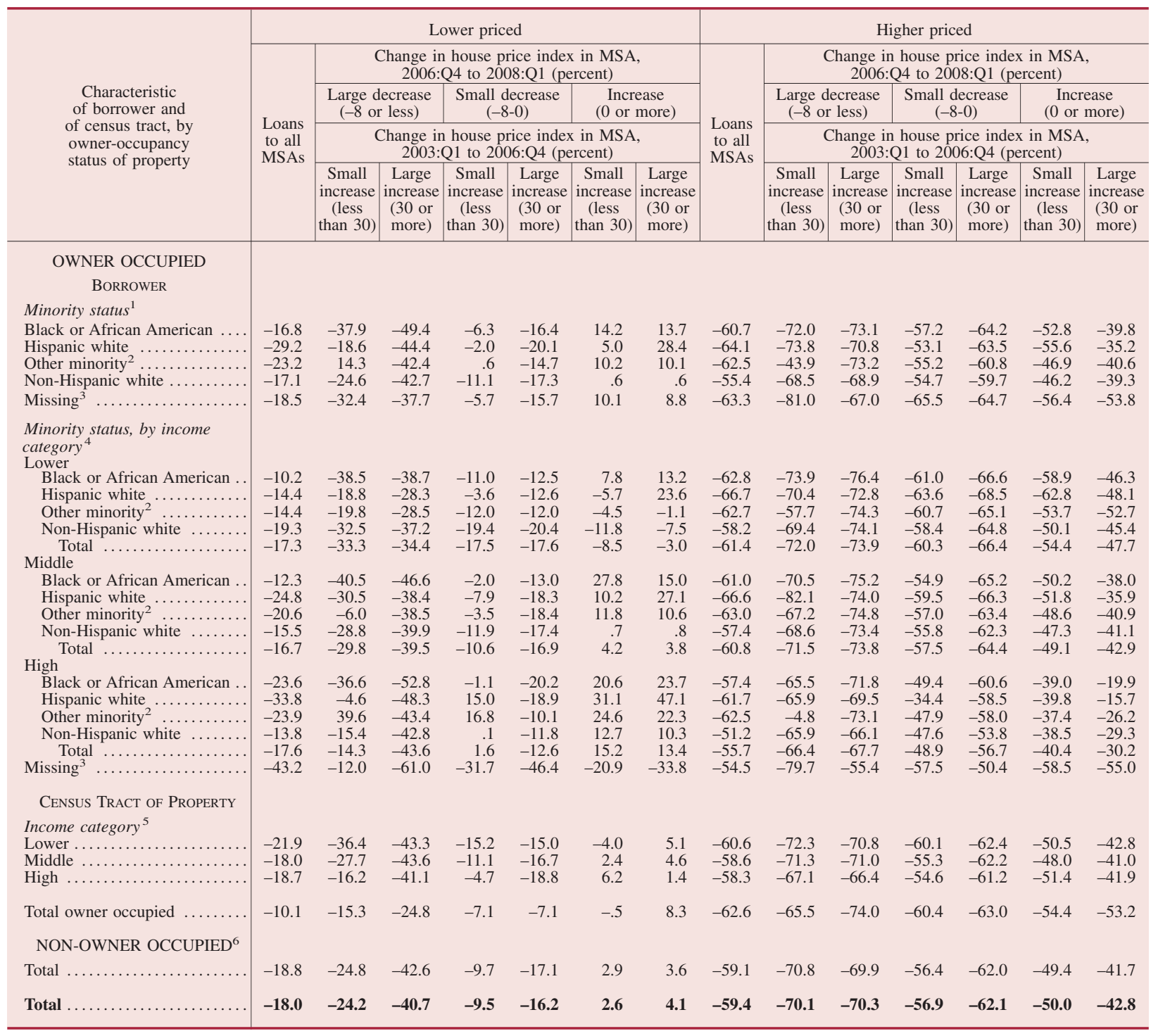

Note: See notes to table 16.A.

loan underwriting or pricing, they are included in the analysis as proxies for at least some of the factors that are considered. Because of the focus here on specific loan product categories, the analysis already accounts in broad terms for loan type and purpose, type of property securing the loan, lien status, and owneroccupancy status. Given that lenders offer a wide variety of conventional loan products for which basic terms can differ substantially, the analysis can only be viewed as suggestive.
The pricing analysis focuses on both the incidence of higher-priced lending and the mean APR spreads paid by borrowers with higher-priced loans. Comparisons of average outcomes for each racial, ethnic, or gender group are made both before and after accounting for differences in the borrower-related factors cited earlier (income; loan amount; location of the property, or MSA; presence of a co-applicant; and, in the comparisons by race and ethnicity, sex) and for differences in borrower-related factors plus the spe- 
17. Change in the number of lower- and higher-priced loan originations for home purchase and for refinancing, by change in mortgage delinquency rate in metropolitan statistical area and by characteristic of borrower and of census tract, 2006:H1 through 2007:H2

Percent

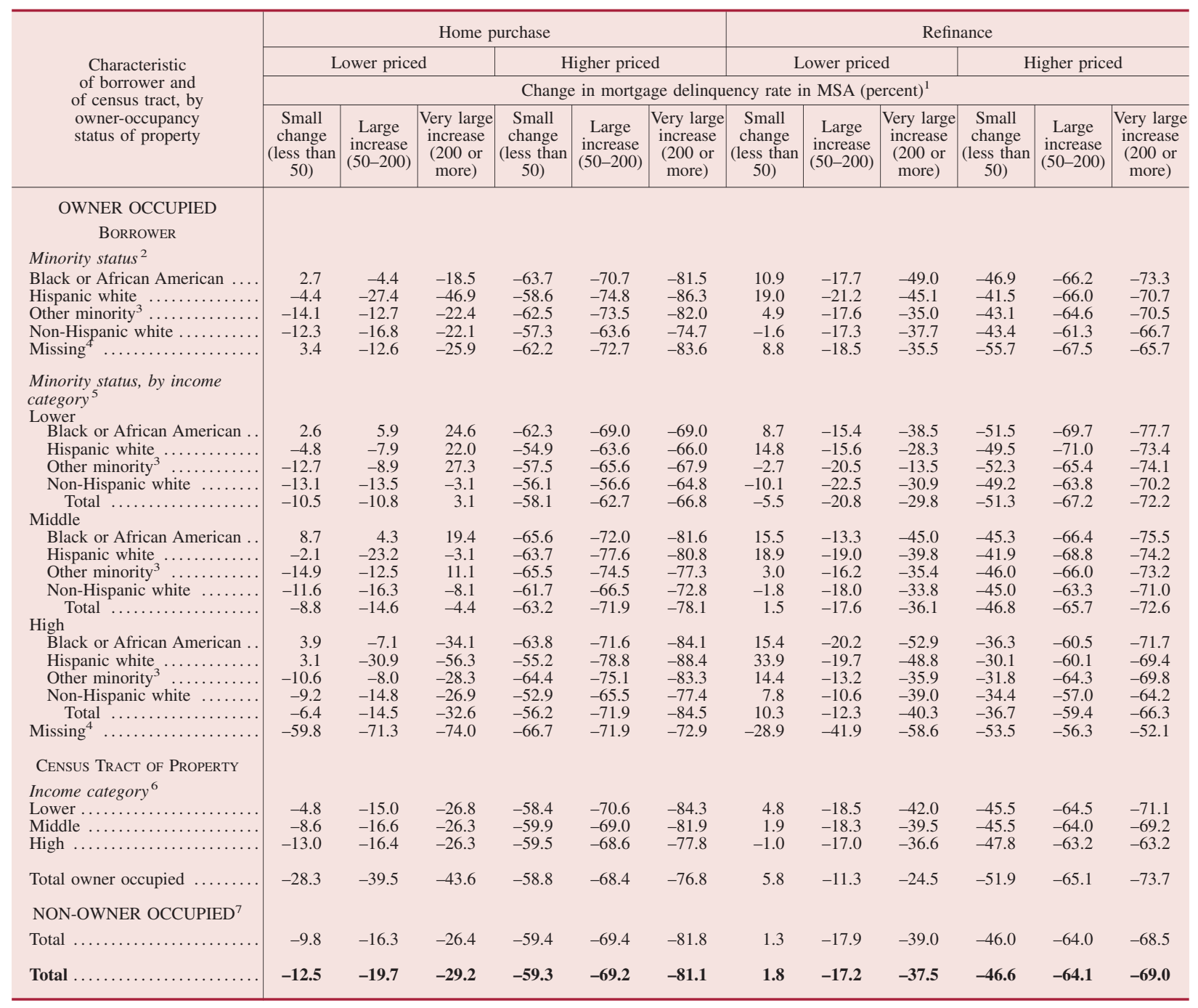

NotE: See general note to table 14.A.

1. Mortgage delinquency rate is the percentage of mortgage borrowers 90 days or more delinquent; calculated using delinquency rates for each metropolitan statistical area (MSA) from 2003:Q4 to 2007:Q4.

2. See note 4 , table 12 .

3. Other minority consists of American Indian or Alaska Native, Asian, and Native Hawaiian or other Pacific Islander.

\footnotetext{
4. Information for the characteristic was missing on the application.

5. See note 2 , table 12 .

6. See note 10 , table 12

7. Includes loans for which occupancy status was missing.

Source: For delinquency rate statistics, Trend Data, a product of TransUnion LLC.
}

cific lending institution used by the borrower. ${ }^{34}$ The method of controlling for these factors is to group borrowers into cells in which the individuals in each cell are similar along each dimension considered.

34. Excluded from the pricing analysis are applicants residing outside the 50 states and the District of Columbia as well as applications deemed to be business related.
Comparisons for lending outcomes across groups are of three types: gross (or "unmodified"), modified to account for borrower-related factors (or "borrower modified"), and modified to account for borrowerrelated factors plus lender (or "lender modified"). For purposes of presentation, the borrower- and lendermodified outcomes shown in the tables are normalized so that, for the base comparison group (non- 
Hispanic whites in the case of comparison by race and ethnicity and males in the case of comparison by sex), the mean at each modification level is the same as the gross mean. Consequently, the borrower- and lender-modified outcomes for any other group represent the expected average outcome under the assumption that the members of that group had the same distribution of control factors (income, loan amount, and the like) as the base comparison group.

As noted earlier, mortgage market conditions changed significantly over the course of 2007. To help account for the possible effects of these changing conditions on the patterns of lending outcomes across population groups, the tables presented in this section show loan activity by half-year for both 2006 and 2007. Our analysis of the lenders that did not report in 2007 but that did so in 2006 indicates that by the second half of 2007 virtually all of these lenders had gone out of business. As noted, these lenders tended to be relatively more focused on the higher-priced segment of the market and on lending to minority borrowers. Consequently, the lending data for the second half of 2007 likely reflect a "truer" picture of the entire market for that period than the data for the first half of 2007, which do not include loans extended during this period by lenders that ultimately ceased operations and did not report.

Although the focus of the discussion that follows is on differences in lending outcomes across groups, it is important to keep in mind that, as shown earlier, the overall, or gross, incidence of higher-priced lending in 2007 fell sharply from 2006. This drop was experienced by all groups of borrowers regardless of race, ethnicity, or sex. The decline is apparent when comparing the unmodified incidences in higher-priced lending in 2007 for different groups with the unmodified incidences experienced by these groups in 2006.

\section{Incidence of Higher-Priced Lending by Race and Ethnicity}

The 2007 HMDA data, like those from earlier years, indicate that black and Hispanic white borrowers are more likely, and Asian borrowers less likely, to obtain loans with prices above the HMDA price-reporting thresholds than are non-Hispanic white borrowers. These relationships are found for both home-purchase loans and refinancings regardless of the specific period considered (tables 18.A and 18.B). Gross differences in the incidence of higher-priced lending between non-Hispanic whites, on the one hand, and blacks or Hispanic whites, on the other, are large, but these differences are substantially reduced after controlling for borrower-related factors plus lender. Dif- ferences in the incidences of higher-priced lending between Asians and non-Hispanic whites are generally relatively small.

In the second half of 2007, for conventional homepurchase loans, the gross mean incidence of higherpriced lending was 29.5 percent for blacks and 9.2 percent for non-Hispanic whites, a difference of 20.3 percentage points (table 18.A). Borrower-related factors included in the HMDA data accounted for 4.3 percentage points of the difference. Controlling further for the lender reduces the remaining gap to 11.1 percentage points. The results for Hispanic whites are similar to those for blacks. The difference between the gross mean incidence of higher-priced lending for Hispanic whites (24.3 percent) and the corresponding incidence for non-Hispanic whites (9.2 percent) is 15.1 percentage points. Borrowerrelated factors included in the HMDA data accounted for 5.7 percentage points of the difference. Controlling further for the lender reduces the remaining gap to 6.2 percentage points. The situation for Asians differs greatly from that for blacks or Hispanic whites: Compared with non-Hispanic whites, Asians had a lower mean incidence of higher-priced lending for home-purchase loans on both a gross and a modified basis.

Comparing the differences in the incidences of higher-priced lending between the various minority groups and non-Hispanic whites in the second half of 2006 with the differences between these groups in the second half of 2007 reveals relatively little change in the gaps modified for borrower-related factors plus lender. For example, the fully modified gap between blacks and non-Hispanic whites was 13.4 percentage points in the second half of 2006 and 11.1 percentage points in the second half of 2007. Similarly, the fully modified gap between Hispanic whites and nonHispanic whites was 6.6 percentage points in the second half of 2006 and 6.2 percentage points in the second half of 2007.

\section{Rate Spreads by Race and Ethnicity}

The 2007 data indicate that among borrowers with higher-priced loans, the gross mean prices paid by black borrowers are moderately higher than-and those paid by Hispanic white borrowers are nearly the same as - those paid by non-Hispanic white borrowers (tables 19.A and 19.B). Asian borrowers with higher-priced loans also paid about the same mean prices, on average, as non-Hispanic whites with such loans. These relationships are little influenced by an accounting for borrower-related factors or the specific lender used by the borrowers. 
18. Incidence of higher-priced lending, unmodified and modified for borrower- and lender-related factors, for conventional first liens on owner-occupied, one- to four-family, site-built homes, by half-year in which loan was originated and by race, ethnicity, and sex of borrower, 2006-07

\section{A. Home purchase}

Percent except as noted

\begin{tabular}{|c|c|c|c|c|c|c|c|c|}
\hline \multirow[b]{2}{*}{ Race, ethnicity, and sex ${ }^{1}$} & \multirow{2}{*}{$\begin{array}{c}\text { Number of } \\
\text { loans }\end{array}$} & \multirow{2}{*}{$\begin{array}{l}\text { Unmodified } \\
\text { incidence }\end{array}$} & \multicolumn{2}{|c|}{$\begin{array}{l}\text { Modified incidence, by } \\
\text { modification factor }\end{array}$} & \multirow{2}{*}{$\begin{array}{c}\text { Number of } \\
\text { loans }\end{array}$} & \multirow{2}{*}{$\begin{array}{c}\text { Unmodified } \\
\text { incidence }\end{array}$} & \multicolumn{2}{|c|}{$\begin{array}{l}\text { Modified incidence, by } \\
\text { modification factor }\end{array}$} \\
\hline & & & $\begin{array}{l}\text { Borrower- } \\
\text { related }\end{array}$ & $\begin{array}{l}\text { Borrower- } \\
\text { related } \\
\text { plus lender }\end{array}$ & & & $\begin{array}{l}\text { Borrower- } \\
\text { related }\end{array}$ & $\begin{array}{l}\text { Borrower- } \\
\text { related } \\
\text { plus lender }\end{array}$ \\
\hline & \multicolumn{8}{|c|}{2006} \\
\hline & \multicolumn{4}{|c|}{$\mathrm{H} 1$} & \multicolumn{4}{|c|}{$\mathrm{H} 2$} \\
\hline 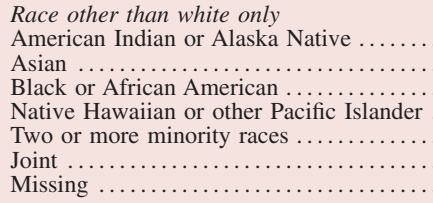 & $\begin{array}{r}11,059 \\
96,781 \\
156,337 \\
9,427 \\
1,038 \\
22,638 \\
187,627\end{array}$ & $\begin{array}{l}35.4 \\
16.8 \\
56.5 \\
34.4 \\
29.6 \\
17.7 \\
28.5\end{array}$ & $\begin{array}{l}30.9 \\
15.8 \\
50.1 \\
30.4 \\
30.5 \\
24.4 \\
31.2\end{array}$ & $\begin{array}{l}25.4 \\
17.3 \\
30.8 \\
23.4 \\
19.8 \\
20.0 \\
23.6\end{array}$ & $\begin{array}{r}10,557 \\
90,424 \\
162,369 \\
9,348 \\
1,074 \\
22,033 \\
190,450\end{array}$ & $\begin{array}{l}32.9 \\
16.7 \\
51.1 \\
33.5 \\
25.7 \\
17.3 \\
29.9\end{array}$ & $\begin{array}{l}30.8 \\
14.7 \\
45.9 \\
28.1 \\
26.7 \\
23.0 \\
32.3\end{array}$ & $\begin{array}{l}23.4 \\
16.5 \\
30.7 \\
21.9 \\
20.6 \\
19.6 \\
23.2\end{array}$ \\
\hline $\begin{array}{l}\text { White, by ethnicity } \\
\text { Hispanic white } \ldots \ldots \ldots \ldots \ldots \ldots \\
\text { Non-Hispanic white } \ldots \ldots \ldots \ldots \ldots\end{array}$ & $\begin{array}{r}235,283 \\
1,219,990\end{array}$ & $\begin{array}{l}48.1 \\
18.1\end{array}$ & $\begin{array}{l}36.9 \\
18.1\end{array}$ & $\begin{array}{l}24.5 \\
18.1\end{array}$ & $\begin{array}{r}229,008 \\
1,186,928\end{array}$ & $\begin{array}{l}45.1 \\
17.3\end{array}$ & $\begin{array}{l}34.0 \\
17.3\end{array}$ & $\begin{array}{l}23.9 \\
17.3\end{array}$ \\
\hline 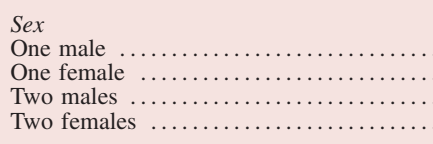 & $\begin{array}{r}635,262 \\
461,907 \\
18,871 \\
15,819\end{array}$ & $\begin{array}{l}33.2 \\
31.8 \\
24.6 \\
26.9\end{array}$ & $\begin{array}{l}33.2 \\
30.9 \\
24.6 \\
23.8\end{array}$ & $\begin{array}{l}33.2 \\
32.0 \\
24.6 \\
24.4\end{array}$ & $\begin{array}{r}620,402 \\
463,186 \\
17,541 \\
15,248\end{array}$ & $\begin{array}{l}31.4 \\
30.0 \\
23.3 \\
25.5\end{array}$ & $\begin{array}{l}31.4 \\
29.3 \\
23.3 \\
21.5\end{array}$ & $\begin{array}{l}31.4 \\
30.2 \\
23.3 \\
22.6\end{array}$ \\
\hline & \multicolumn{8}{|c|}{2007} \\
\hline & \multicolumn{4}{|c|}{ H1 } & \multicolumn{4}{|c|}{$\mathrm{H} 2$} \\
\hline 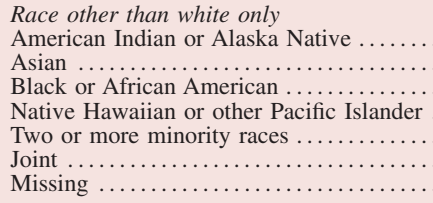 & $\begin{array}{r}7,437 \\
75,610 \\
110,747 \\
6,410 \\
902 \\
18,781 \\
146,171\end{array}$ & $\begin{array}{r}22.0 \\
9.6 \\
37.8 \\
20.8 \\
15.5 \\
10.4 \\
16.7\end{array}$ & $\begin{array}{r}21.1 \\
9.9 \\
34.1 \\
19.5 \\
13.6 \\
15.2 \\
21.3\end{array}$ & $\begin{array}{l}17.2 \\
11.0 \\
24.5 \\
15.4 \\
15.7 \\
13.0 \\
16.2\end{array}$ & $\begin{array}{r}6,241 \\
70,801 \\
86,220 \\
5,347 \\
974 \\
17,769 \\
131,177\end{array}$ & $\begin{array}{r}17.5 \\
5.6 \\
29.5 \\
14.1 \\
10.6 \\
7.3 \\
11.4\end{array}$ & $\begin{array}{r}14.7 \\
6.9 \\
25.2 \\
14.4 \\
11.8 \\
11.3 \\
15.4\end{array}$ & $\begin{array}{r}15.1 \\
7.8 \\
20.3 \\
12.8 \\
12.7 \\
10.5 \\
12.3\end{array}$ \\
\hline $\begin{array}{l}\text { White, by ethnicity } \\
\text { Hispanic white } \ldots \ldots \\
\text { Non-Hispanic white }\end{array}$ & $\begin{array}{r}152,901 \\
1,031,059\end{array}$ & $\begin{array}{l}31.8 \\
11.8\end{array}$ & $\begin{array}{l}23.9 \\
11.8\end{array}$ & $\begin{array}{l}17.6 \\
11.8\end{array}$ & $\begin{array}{l}109,034 \\
919,507\end{array}$ & $\begin{array}{r}24.3 \\
9.2\end{array}$ & $\begin{array}{r}18.6 \\
9.2\end{array}$ & $\begin{array}{r}15.4 \\
9.2\end{array}$ \\
\hline $\begin{array}{l}\text { Sex } \\
\text { One male } \ldots \ldots . . \\
\text { One female } \ldots . . \\
\text { Two males ...... } \\
\text { Two females } \ldots . .\end{array}$ & $\begin{array}{r}500,468 \\
362,266 \\
14,504 \\
12,553\end{array}$ & $\begin{array}{l}20.8 \\
19.3 \\
16.4 \\
17.7\end{array}$ & $\begin{array}{l}20.8 \\
18.7 \\
16.4 \\
15.0\end{array}$ & $\begin{array}{l}20.8 \\
19.5 \\
16.4 \\
16.5\end{array}$ & $\begin{array}{r}405,659 \\
301,836 \\
14,145 \\
11,886\end{array}$ & $\begin{array}{l}15.9 \\
14.4 \\
12.8 \\
12.8\end{array}$ & $\begin{array}{l}15.9 \\
13.6 \\
12.8 \\
11.4\end{array}$ & $\begin{array}{l}15.9 \\
14.3 \\
12.8 \\
12.6\end{array}$ \\
\hline
\end{tabular}

Note: Excludes transition-period loans (those for which the application was submitted before 2004). For definition of higher-priced lending, see text note 7; for explanation of modification factors, see text.

\section{Pricing Differences by Sex}

The 2007 HMDA data, like those in previous years, reveal relatively little difference in pricing outcomes when borrowers are distinguished by sex, although single males experienced a somewhat higher modified incidence of higher-priced lending than single females (tables 18.A and 18.B). The mean APR spreads paid by females are virtually the same as those paid by males after accounting for the presence or absence of a co-borrower (tables 19.A and 19.B).

\section{Denial Rates by Race, Ethnicity, and Sex}

Analyses of the HMDA data from earlier years have consistently found that denial rates vary across appli-
1. See note 4 , table 12 . Loans taken out jointly by a male and female are not tabulated here because they would not be directly comparable with loans taken out by one borrower or by two borrowers of the same sex.

cants grouped by race or ethnicity. For each broad loan product category in 2007 (first or second half), American Indians, blacks, and Hispanic whites had higher gross denial rates than non-Hispanic whites; blacks generally had the highest rates, and Hispanic whites had rates between those for blacks and those for non-Hispanic whites (tables 20.A and 20.B). The pattern for Asians was somewhat different, as the gross denial rate for them was either lower than, or very similar to, the rate for non-Hispanic whites, depending on the period and the loan purpose.

Controlling for borrower-related factors in the HMDA data reduces the differences among racial and ethnic groups. Accounting for the specific lender used by the applicant almost always reduces differences 
18. Incidence of higher-priced lending, unmodified and modified for borrower- and lender-related factors, for conventional first liens on owner-occupied, one- to four-family, site-built homes, by half-year in which loan was originated and by race, ethnicity, and sex of borrower, 2006-07-Continued

B. Refinance

Percent except as noted

\begin{tabular}{|c|c|c|c|c|c|c|c|c|}
\hline \multirow[b]{2}{*}{ Race, ethnicity, and sex ${ }^{1}$} & \multirow[b]{2}{*}{$\begin{array}{l}\text { Number of } \\
\text { loans }\end{array}$} & \multirow{2}{*}{$\begin{array}{l}\text { Unmodified } \\
\text { incidence }\end{array}$} & \multicolumn{2}{|c|}{$\begin{array}{l}\text { Modified incidence, by } \\
\text { modification factor }\end{array}$} & \multirow{2}{*}{$\begin{array}{l}\text { Number of } \\
\text { loans }\end{array}$} & \multirow{2}{*}{$\begin{array}{l}\text { Unmodified } \\
\text { incidence }\end{array}$} & \multicolumn{2}{|c|}{$\begin{array}{l}\text { Modified incidence, by } \\
\text { modification factor }\end{array}$} \\
\hline & & & $\begin{array}{l}\text { Borrower- } \\
\text { related }\end{array}$ & $\begin{array}{l}\text { Borrower- } \\
\text { related } \\
\text { plus lender }\end{array}$ & & & $\begin{array}{l}\text { Borrower- } \\
\text { related }\end{array}$ & $\begin{array}{l}\text { Borrower- } \\
\text { related } \\
\text { plus lender }\end{array}$ \\
\hline & \multicolumn{8}{|c|}{2006} \\
\hline & \multicolumn{4}{|c|}{ H1 } & \multicolumn{4}{|c|}{$\mathrm{H} 2$} \\
\hline 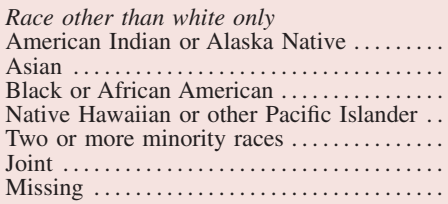 & $\begin{array}{r}14,030 \\
61,485 \\
195,050 \\
12,282 \\
1,474 \\
21,091 \\
281,183\end{array}$ & $\begin{array}{l}31.2 \\
17.6 \\
52.0 \\
31.1 \\
27.1 \\
25.4 \\
36.3\end{array}$ & $\begin{array}{l}34.9 \\
22.2 \\
49.4 \\
36.5 \\
29.5 \\
32.5 \\
42.3\end{array}$ & $\begin{array}{l}28.6 \\
24.7 \\
31.9 \\
28.3 \\
28.6 \\
26.4 \\
29.6\end{array}$ & $\begin{array}{r}13,718 \\
66,388 \\
202,412 \\
11,796 \\
1,439 \\
20,784 \\
289,263\end{array}$ & $\begin{array}{l}34.4 \\
21.5 \\
53.6 \\
36.3 \\
28.8 \\
27.0 \\
40.1\end{array}$ & $\begin{array}{l}37.6 \\
25.2 \\
50.8 \\
38.9 \\
29.3 \\
34.1 \\
45.1\end{array}$ & $\begin{array}{l}29.9 \\
25.8 \\
34.4 \\
31.4 \\
33.4 \\
27.8 \\
32.0\end{array}$ \\
\hline $\begin{array}{l}\text { White, by ethnicity } \\
\text { Hispanic white } \ldots \ldots \ldots \ldots \ldots \ldots \ldots \ldots \ldots \ldots \ldots \ldots \ldots \ldots \\
\text { Non-Hispanic white } \ldots \ldots \ldots \ldots \ldots \ldots \ldots\end{array}$ & $\begin{array}{r}213,338 \\
1,296,597\end{array}$ & $\begin{array}{l}35.4 \\
25.0\end{array}$ & $\begin{array}{l}36.4 \\
25.0\end{array}$ & $\begin{array}{l}28.4 \\
25.0\end{array}$ & $\begin{array}{r}223,825 \\
1,300,339\end{array}$ & $\begin{array}{l}39.9 \\
26.5\end{array}$ & $\begin{array}{l}37.7 \\
26.5\end{array}$ & $\begin{array}{l}31.0 \\
26.5\end{array}$ \\
\hline 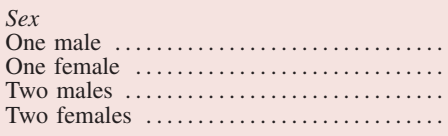 & $\begin{array}{r}591,436 \\
506,018 \\
13,457 \\
15,620\end{array}$ & $\begin{array}{l}33.4 \\
34.1 \\
26.3 \\
33.2\end{array}$ & $\begin{array}{l}33.4 \\
32.8 \\
26.3 \\
28.9\end{array}$ & $\begin{array}{l}33.4 \\
33.1 \\
26.3 \\
27.2\end{array}$ & $\begin{array}{r}605,743 \\
527,701 \\
13,879 \\
15,559\end{array}$ & $\begin{array}{l}35.8 \\
36.6 \\
27.0 \\
35.1\end{array}$ & $\begin{array}{l}35.8 \\
35.6 \\
27.0 \\
30.6\end{array}$ & $\begin{array}{l}35.8 \\
35.8 \\
27.0 \\
26.0\end{array}$ \\
\hline \multirow{2}{*}{ Two females $\ldots . \ldots \ldots \ldots \ldots \ldots \ldots \ldots$} & \multicolumn{8}{|c|}{2007} \\
\hline & \multicolumn{4}{|c|}{$\mathrm{H} 1$} & \multicolumn{4}{|c|}{$\mathrm{H} 2$} \\
\hline 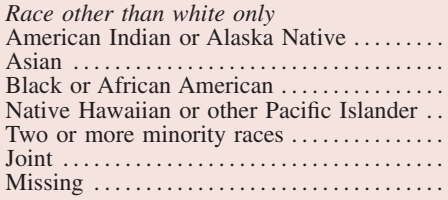 & $\begin{array}{r}11,480 \\
63,999 \\
158,416 \\
9,518 \\
1,434 \\
19,892 \\
258,895\end{array}$ & $\begin{array}{l}28.1 \\
15.4 \\
44.6 \\
25.7 \\
20.2 \\
19.6 \\
29.5\end{array}$ & $\begin{array}{l}31.0 \\
17.5 \\
41.6 \\
29.1 \\
23.2 \\
24.8 \\
35.3\end{array}$ & $\begin{array}{l}22.1 \\
18.8 \\
27.1 \\
24.3 \\
22.2 \\
20.4 \\
25.2\end{array}$ & $\begin{array}{r}8,028 \\
44,318 \\
108,245 \\
6,283 \\
1,122 \\
14,413 \\
179,528\end{array}$ & $\begin{array}{r}23.9 \\
8.4 \\
36.8 \\
18.9 \\
14.1 \\
17.2 \\
20.6\end{array}$ & $\begin{array}{l}26.2 \\
13.5 \\
35.4 \\
24.3 \\
16.1 \\
21.6 \\
25.7\end{array}$ & $\begin{array}{l}18.2 \\
14.9 \\
22.6 \\
19.0 \\
18.7 \\
17.0 \\
20.1\end{array}$ \\
\hline $\begin{array}{l}\text { White, by ethnicity } \\
\text { Hispanic white } \ldots \ldots \ldots \ldots \ldots \ldots \ldots \ldots \\
\text { Non-Hispanic white } \ldots \ldots \ldots \ldots \ldots \ldots\end{array}$ & $\begin{array}{r}180,394 \\
1,238,650\end{array}$ & $\begin{array}{l}30.2 \\
19.8\end{array}$ & $\begin{array}{l}28.3 \\
19.8\end{array}$ & $\begin{array}{l}23.4 \\
19.8\end{array}$ & $\begin{array}{l}121,618 \\
935,658\end{array}$ & $\begin{array}{l}22.3 \\
16.2\end{array}$ & $\begin{array}{l}21.9 \\
16.2\end{array}$ & $\begin{array}{l}19.1 \\
16.2\end{array}$ \\
\hline 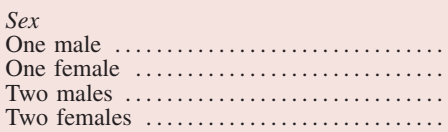 & $\begin{array}{r}546,140 \\
451,279 \\
12,931 \\
13,992\end{array}$ & $\begin{array}{l}26.6 \\
27.6 \\
21.0 \\
28.5\end{array}$ & $\begin{array}{l}26.6 \\
26.7 \\
21.0 \\
24.0\end{array}$ & $\begin{array}{l}26.6 \\
26.5 \\
21.0 \\
22.7\end{array}$ & $\begin{array}{r}381,204 \\
327,198 \\
10,216 \\
11,371\end{array}$ & $\begin{array}{l}19.9 \\
21.1 \\
17.4 \\
24.2\end{array}$ & $\begin{array}{l}19.9 \\
19.8 \\
17.4 \\
20.2\end{array}$ & $\begin{array}{l}19.9 \\
19.4 \\
17.4 \\
18.8\end{array}$ \\
\hline
\end{tabular}

NotE: See notes to table 18.A.

further, although unexplained differences remain between non-Hispanic whites and other racial and ethnic groups.

With regard to the sex of applicants, sole male applicants have marginally higher gross and modified denial rates than single females. Also, dual male borrowers and dual female borrowers generally have very similar denial rates, which are somewhat lower than those for single applicants.

\section{Some Limitations of the Data in Assessing Fair Lending Compliance}

Information in the HMDA data, including borrower income, loan amount, location of the property, date of loan origination, and the specific lender used, is insufficient to account fully for racial or ethnic differences in the incidence of higher-priced lending; significant differences remain unexplained. Similar patterns are shown in racial or ethnic differences in denial rates. In contrast, only small differences across groups were found in the mean APR spreads paid by those receiving higher-priced loans. Regarding the sex of borrowers, some very small differences were found in lending outcomes.

Both previous research and experience gained in the fair lending enforcement process show that unexplained differences in the incidence of higher-priced lending and in denial rates among racial or ethnic groups stem in part from credit-related factors not available in the HMDA data, such as measures of 
19. Mean APR spreads, unmodified and modified for borrower- and lender-related factors, for higher-priced conventional first liens on owner-occupied, one- to four-family, site-built homes, by half-year in which loan was originated and by race, ethnicity, and sex of borrower, 2006-07

A. Home purchase

Percentage points except as noted

\begin{tabular}{|c|c|c|c|c|c|c|c|c|}
\hline \multirow[b]{2}{*}{ Race, ethnicity, and $\operatorname{sex}^{1}$} & \multirow{2}{*}{$\begin{array}{c}\text { Number of } \\
\text { higher-priced } \\
\text { loans }\end{array}$} & \multirow{2}{*}{$\begin{array}{c}\text { Unmodified } \\
\text { mean spread }\end{array}$} & \multicolumn{2}{|c|}{$\begin{array}{l}\text { Modified mean spread, by } \\
\text { modification factor }\end{array}$} & \multirow{2}{*}{$\begin{array}{c}\text { Number of } \\
\text { higher-priced } \\
\text { loans }\end{array}$} & \multirow{2}{*}{$\begin{array}{l}\text { Unmodified } \\
\text { mean spread }\end{array}$} & \multicolumn{2}{|c|}{$\begin{array}{l}\text { Modified mean spread, by } \\
\text { modification factor }\end{array}$} \\
\hline & & & $\begin{array}{c}\text { Borrower- } \\
\text { related }\end{array}$ & $\begin{array}{l}\text { Borrower- } \\
\text { related } \\
\text { plus lender }\end{array}$ & & & $\begin{array}{c}\text { Borrower- } \\
\text { related }\end{array}$ & $\begin{array}{c}\text { Borrower- } \\
\text { related } \\
\text { plus lender }\end{array}$ \\
\hline & \multicolumn{8}{|c|}{2006} \\
\hline & \multicolumn{4}{|c|}{$\mathrm{H} 1$} & \multicolumn{4}{|c|}{$\mathrm{H} 2$} \\
\hline 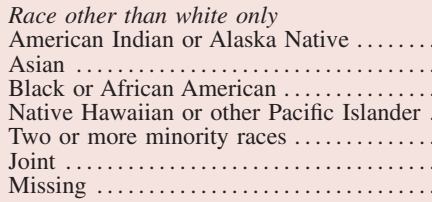 & $\begin{array}{r}3,911 \\
16,307 \\
88,335 \\
3,247 \\
307 \\
3,999 \\
53,557\end{array}$ & $\begin{array}{l}5.25 \\
5.11 \\
5.69 \\
5.25 \\
5.42 \\
5.30 \\
5.41\end{array}$ & $\begin{array}{l}5.23 \\
5.13 \\
5.64 \\
5.22 \\
5.38 \\
5.34 \\
5.43\end{array}$ & $\begin{array}{l}5.17 \\
5.15 \\
5.34 \\
5.14 \\
5.16 \\
5.19 \\
5.28\end{array}$ & $\begin{array}{r}3,478 \\
15,089 \\
82,903 \\
3,130 \\
276 \\
3,803 \\
56,977\end{array}$ & $\begin{array}{l}5.12 \\
4.97 \\
5.66 \\
5.17 \\
5.43 \\
5.30 \\
5.51\end{array}$ & $\begin{array}{l}5.13 \\
5.07 \\
5.59 \\
5.15 \\
5.45 \\
5.29 \\
5.55\end{array}$ & $\begin{array}{l}5.11 \\
5.11 \\
5.31 \\
5.17 \\
5.37 \\
5.12 \\
5.26\end{array}$ \\
\hline $\begin{array}{l}\text { White, by ethnicity } \\
\text { Hispanic white ..... } \\
\text { Non-Hispanic white }\end{array}$ & $\begin{array}{l}113,136 \\
221,352\end{array}$ & $\begin{array}{l}5.28 \\
5.16\end{array}$ & $\begin{array}{l}5.20 \\
5.16\end{array}$ & $\begin{array}{l}5.18 \\
5.16\end{array}$ & $\begin{array}{l}103,286 \\
204,795\end{array}$ & $\begin{array}{l}5.24 \\
5.13\end{array}$ & $\begin{array}{l}5.16 \\
5.13\end{array}$ & $\begin{array}{l}5.14 \\
5.13\end{array}$ \\
\hline $\begin{array}{l}\text { Sex } \\
\text { One male } \ldots \ldots \ldots \ldots \\
\text { One female } \ldots \ldots \ldots \ldots \\
\text { Two males } \ldots \ldots \ldots \ldots \\
\text { Two females } \ldots \ldots \ldots\end{array}$ & $\begin{array}{r}210,792 \\
147,065 \\
4,634 \\
4,254\end{array}$ & $\begin{array}{l}5.33 \\
5.35 \\
5.15 \\
5.41\end{array}$ & $\begin{array}{l}5.33 \\
5.34 \\
5.15 \\
5.33\end{array}$ & $\begin{array}{l}5.33 \\
5.31 \\
5.15 \\
5.24\end{array}$ & $\begin{array}{r}194,624 \\
138,876 \\
4,084 \\
3,889\end{array}$ & $\begin{array}{l}5.30 \\
5.31 \\
5.23 \\
5.45\end{array}$ & $\begin{array}{l}5.30 \\
5.31 \\
5.23 \\
5.35\end{array}$ & $\begin{array}{l}5.30 \\
5.29 \\
5.23 \\
5.32\end{array}$ \\
\hline \multirow{2}{*}{ Two females } & \multicolumn{8}{|c|}{2007} \\
\hline & \multicolumn{4}{|c|}{ H1 } & \multicolumn{4}{|c|}{$\mathrm{H} 2$} \\
\hline 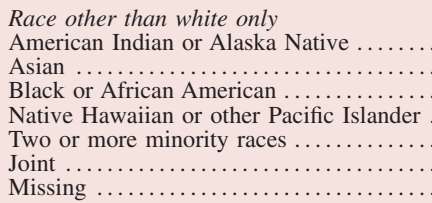 & $\begin{array}{r}1,634 \\
7,295 \\
41,836 \\
1,332 \\
140 \\
1,958 \\
24,339\end{array}$ & $\begin{array}{l}4.71 \\
4.50 \\
5.24 \\
4.80 \\
5.05 \\
4.96 \\
4.96\end{array}$ & $\begin{array}{l}4.68 \\
4.59 \\
5.19 \\
4.81 \\
5.17 \\
4.92 \\
5.09\end{array}$ & $\begin{array}{l}4.73 \\
4.67 \\
4.92 \\
4.77 \\
4.91 \\
4.80 \\
4.86\end{array}$ & $\begin{array}{r}1,093 \\
3,968 \\
25,395 \\
754 \\
103 \\
1,306 \\
14,928\end{array}$ & $\begin{array}{l}4.07 \\
3.90 \\
4.44 \\
4.02 \\
4.40 \\
4.19 \\
4.21\end{array}$ & $\begin{array}{l}4.17 \\
3.94 \\
4.47 \\
4.17 \\
4.35 \\
4.19 \\
4.33\end{array}$ & $\begin{array}{l}4.08 \\
4.01 \\
4.32 \\
4.10 \\
4.34 \\
4.08 \\
4.23\end{array}$ \\
\hline $\begin{array}{l}\text { White, by ethnicity } \\
\text { Hispanic white } . . . . \\
\text { Non-Hispanic white }\end{array}$ & $\begin{array}{r}48,619 \\
121,526\end{array}$ & $\begin{array}{l}4.77 \\
4.66\end{array}$ & $\begin{array}{l}4.70 \\
4.66\end{array}$ & $\begin{array}{l}4.71 \\
4.66\end{array}$ & $\begin{array}{l}26,484 \\
84,943\end{array}$ & $\begin{array}{l}4.06 \\
4.06\end{array}$ & $\begin{array}{l}4.13 \\
4.06\end{array}$ & $\begin{array}{l}4.07 \\
4.06\end{array}$ \\
\hline $\begin{array}{l}\text { Sex } \\
\text { One male } \ldots \ldots \ldots \ldots \ldots \ldots \ldots \\
\text { One female } \ldots \ldots \ldots \ldots \ldots \ldots \ldots \\
\text { Two males } \ldots \ldots \ldots \ldots \ldots \ldots \ldots \ldots \\
\text { Two females } \ldots \ldots \ldots \ldots \ldots \ldots \ldots\end{array}$ & $\begin{array}{r}104,020 \\
69,928 \\
2,377 \\
2,219\end{array}$ & $\begin{array}{l}4.80 \\
4.80 \\
4.85 \\
5.18\end{array}$ & $\begin{array}{l}4.80 \\
4.82 \\
4.85 \\
4.99\end{array}$ & $\begin{array}{l}4.80 \\
4.81 \\
4.85 \\
4.88\end{array}$ & $\begin{array}{r}64,664 \\
43,499 \\
1,812 \\
1,524\end{array}$ & $\begin{array}{l}4.14 \\
4.11 \\
4.14 \\
4.26\end{array}$ & $\begin{array}{l}4.14 \\
4.10 \\
4.14 \\
4.10\end{array}$ & $\begin{array}{l}4.14 \\
4.12 \\
4.14 \\
4.40\end{array}$ \\
\hline
\end{tabular}

NOTE: Spread is the difference between the annual percentage rate (APR) on the loan and the yield on a comparable-maturity Treasury security. Excludes transition-period loans (those for which the application was submitted before 2004). For definition of higher-priced lending, see text note 7; for explanation of modification factors, see text. See also note 1, table 18.A.

credit history (including credit scores), loan-to-value and debt-to-income ratios, and differences in choice of loan products. Differential costs of loan origination and the competitive environment also may bear on the differences in pricing, as may differences across populations in credit-shopping activities.

Differences in pricing and underwriting outcomes may also reflect discriminatory treatment of minorities or other actions by lenders, including marketing practices. The HMDA data are regularly used to facilitate the fair lending examination and enforcement processes. When examiners for the federal banking agencies evaluate an institution's fair lending risk, they analyze HMDA price data in conjunction with other information and risk factors, as directed by the Interagency Fair Lending Examination Procedures. ${ }^{35}$ Risk factors for pricing discrimination include, but are not limited to, the relationship between loan pricing and compensation of loan officers or brokers, the presence of broad pricing discretion, and consumer complaints.

It is difficult to draw conclusions from the HMDA data about changes in the fair lending environment from 2006 to 2007. For example, denial rate differences between non-Hispanic whites and minorities

35. The Interagency Fair Lending Examination Procedures are available at www.ffiec.gov/PDF/fairlend.pdf. 
19. Mean APR spreads, unmodified and modified for borrower- and lender-related factors, for higher-priced conventional first liens on owner-occupied, one- to four-family, site-built homes, by half-year in which loan was originated and by race, ethnicity, and sex of borrower, 2006-07-Continued

\section{B. Refinance}

Percentage points except as noted

\begin{tabular}{|c|c|c|c|c|c|c|c|c|}
\hline \multirow[b]{2}{*}{ Race, ethnicity, and sex ${ }^{1}$} & \multirow{2}{*}{$\begin{array}{c}\text { Number of } \\
\text { higher-priced } \\
\text { loans }\end{array}$} & \multirow{2}{*}{$\begin{array}{l}\text { Unmodified } \\
\text { mean spread }\end{array}$} & \multicolumn{2}{|c|}{$\begin{array}{l}\text { Modified mean spread, by } \\
\text { modification factor }\end{array}$} & \multirow{2}{*}{$\begin{array}{c}\text { Number of } \\
\text { higher-priced } \\
\text { loans }\end{array}$} & \multirow{2}{*}{$\begin{array}{l}\text { Unmodified } \\
\text { mean spread }\end{array}$} & \multicolumn{2}{|c|}{$\begin{array}{l}\text { Modified mean spread, by } \\
\text { modification factor }\end{array}$} \\
\hline & & & $\begin{array}{l}\text { Borrower- } \\
\text { related }\end{array}$ & $\begin{array}{l}\text { Borrower- } \\
\text { related } \\
\text { plus lender }\end{array}$ & & & $\begin{array}{l}\text { Borrower- } \\
\text { related }\end{array}$ & $\begin{array}{l}\text { Borrower- } \\
\text { related } \\
\text { plus lender }\end{array}$ \\
\hline & \multicolumn{8}{|c|}{2006} \\
\hline & \multicolumn{4}{|c|}{$\mathrm{H} 1$} & \multicolumn{4}{|c|}{$\mathrm{H} 2$} \\
\hline 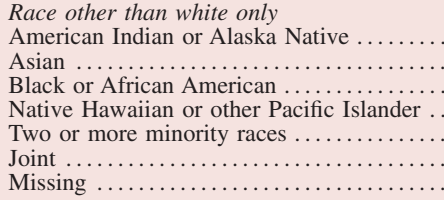 & $\begin{array}{r}4,376 \\
10,815 \\
101,506 \\
3,819 \\
400 \\
5,354 \\
101,960\end{array}$ & $\begin{array}{l}5.14 \\
5.11 \\
5.42 \\
5.29 \\
5.27 \\
5.08 \\
5.35\end{array}$ & $\begin{array}{l}5.09 \\
5.09 \\
5.37 \\
5.21 \\
5.18 \\
5.14 \\
5.36\end{array}$ & $\begin{array}{l}5.14 \\
5.14 \\
5.23 \\
5.21 \\
5.20 \\
5.16 \\
5.16\end{array}$ & $\begin{array}{r}4,720 \\
14,281 \\
108,406 \\
4,283 \\
415 \\
5,604 \\
115,955\end{array}$ & $\begin{array}{l}4.98 \\
4.68 \\
5.30 \\
5.01 \\
5.20 \\
4.96 \\
5.20\end{array}$ & $\begin{array}{l}5.05 \\
4.91 \\
5.24 \\
5.07 \\
5.31 \\
5.07 \\
5.25\end{array}$ & $\begin{array}{l}5.09 \\
5.00 \\
5.08 \\
5.03 \\
5.11 \\
5.03 \\
5.02\end{array}$ \\
\hline $\begin{array}{l}\text { White, by ethnicity } \\
\text { Hispanic white } \ldots \ldots \ldots \ldots \ldots \ldots \ldots \ldots \ldots \ldots \ldots \\
\text { Non-Hispanic white } \ldots \ldots \ldots \ldots \ldots \ldots \ldots\end{array}$ & $\begin{array}{r}75,512 \\
324,384\end{array}$ & $\begin{array}{l}5.27 \\
5.13\end{array}$ & $\begin{array}{l}5.22 \\
5.13\end{array}$ & $\begin{array}{l}5.17 \\
5.13\end{array}$ & $\begin{array}{r}89,236 \\
343,955\end{array}$ & $\begin{array}{l}5.00 \\
4.98\end{array}$ & $\begin{array}{l}5.04 \\
4.98\end{array}$ & $\begin{array}{l}5.04 \\
4.98\end{array}$ \\
\hline 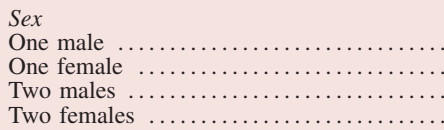 & $\begin{array}{r}197,567 \\
172,442 \\
3,533 \\
5,185\end{array}$ & $\begin{array}{l}5.29 \\
5.30 \\
5.08 \\
5.17\end{array}$ & $\begin{array}{l}5.29 \\
5.28 \\
5.08 \\
5.11\end{array}$ & $\begin{array}{l}5.29 \\
5.29 \\
5.08 \\
4.99\end{array}$ & $\begin{array}{r}216,821 \\
192,926 \\
3,743 \\
5,461\end{array}$ & $\begin{array}{l}5.09 \\
5.12 \\
5.02 \\
5.11\end{array}$ & $\begin{array}{l}5.09 \\
5.09 \\
5.02 \\
5.00\end{array}$ & $\begin{array}{l}5.09 \\
5.09 \\
5.02 \\
5.09\end{array}$ \\
\hline & \multicolumn{8}{|c|}{2007} \\
\hline & \multicolumn{4}{|c|}{ H1 } & \multicolumn{4}{|c|}{$\mathrm{H} 2$} \\
\hline 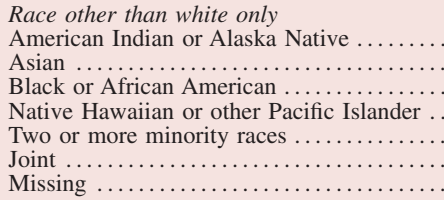 & $\begin{array}{r}3,227 \\
9,848 \\
70,628 \\
2,450 \\
289 \\
3,891 \\
76,469\end{array}$ & $\begin{array}{l}4.79 \\
4.37 \\
5.12 \\
4.70 \\
4.85 \\
4.85 \\
5.02\end{array}$ & $\begin{array}{l}4.77 \\
4.72 \\
5.07 \\
4.79 \\
4.86 \\
4.92 \\
5.09\end{array}$ & $\begin{array}{l}4.88 \\
4.80 \\
4.92 \\
4.88 \\
4.89 \\
4.91 \\
4.82\end{array}$ & $\begin{array}{r}1,918 \\
3,733 \\
39,836 \\
1,189 \\
158 \\
2,474 \\
37,003\end{array}$ & $\begin{array}{l}4.73 \\
4.11 \\
4.96 \\
4.49 \\
4.82 \\
4.69 \\
4.60\end{array}$ & $\begin{array}{l}4.79 \\
4.44 \\
5.00 \\
4.81 \\
4.94 \\
4.82 \\
4.72\end{array}$ & $\begin{array}{l}4.67 \\
4.51 \\
4.75 \\
4.67 \\
4.63 \\
4.64 \\
4.59\end{array}$ \\
\hline $\begin{array}{l}\text { White, by ethnicity } \\
\text { Hispanic white } \ldots \ldots \ldots \ldots \ldots \ldots \ldots \ldots \ldots \ldots \ldots \ldots \\
\text { Non-Hispanic white } \ldots \ldots \ldots \ldots \ldots \ldots \ldots\end{array}$ & $\begin{array}{r}54,477 \\
245,074\end{array}$ & $\begin{array}{l}4.79 \\
4.79\end{array}$ & $\begin{array}{l}4.87 \\
4.79\end{array}$ & $\begin{array}{l}4.89 \\
4.79\end{array}$ & $\begin{array}{r}27,151 \\
151,120\end{array}$ & $\begin{array}{l}4.46 \\
4.58\end{array}$ & $\begin{array}{l}4.60 \\
4.58\end{array}$ & $\begin{array}{l}4.62 \\
4.58\end{array}$ \\
\hline 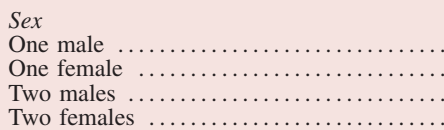 & $\begin{array}{r}145,314 \\
124,764 \\
2,721 \\
3,994\end{array}$ & $\begin{array}{l}4.88 \\
4.88 \\
4.90 \\
5.04\end{array}$ & $\begin{array}{l}4.88 \\
4.85 \\
4.90 \\
4.91\end{array}$ & $\begin{array}{l}4.88 \\
4.87 \\
4.90 \\
4.91\end{array}$ & $\begin{array}{r}75,729 \\
68,930 \\
1,781 \\
2,756\end{array}$ & $\begin{array}{l}4.56 \\
4.60 \\
4.57 \\
4.72\end{array}$ & $\begin{array}{l}4.56 \\
4.56 \\
4.57 \\
4.59\end{array}$ & $\begin{array}{l}4.56 \\
4.54 \\
4.57 \\
4.61\end{array}$ \\
\hline
\end{tabular}

NotE: See note to table 19.A.

widened from 2006 to 2007, although this development may have reflected differences in the credit characteristics or other circumstances of the pools of borrowers in the two years and not unfair treatment by lenders. Similarly, differences between nonHispanic whites and minorities in the incidence of higher-priced lending generally declined, although the fully modified differences narrowed proportionately less than the gross differences. Given the substantial decrease in overall higher-priced lending, it is difficult to know if this narrowing of the differences in the incidence of higher-priced lending was due to any change in the relative treatment of minorities or to changes in the credit profiles of marginal borrowers resulting from declines in applications and increased denial rates.

\section{APPENDIX A: \\ REQUIREMENTS OF REGULATION C}

The Federal Reserve Board's Regulation C requires lenders to report the following information on homepurchase and home-improvement loans and on refinancings:

\section{For each application or loan}

- application date and the date an action was taken on the application

- action taken on the application

- approved and originated

- approved but not accepted by the applicant

— denied (with the reasons for denial-voluntary for some lenders) 
20. Denial rates on applications, unmodified and modified for borrower- and lender-related factors, for conventional first liens on owner-occupied, one- to four-family, site-built homes, by half-year in which application was acted upon by lender and by race, ethnicity, and sex of applicant, 2006-07
A. Home purchase

Percent except as noted

\begin{tabular}{|c|c|c|c|c|c|c|c|c|}
\hline \multirow[b]{2}{*}{ Race, ethnicity, and sex ${ }^{1}$} & \multirow{2}{*}{$\begin{array}{l}\text { Number of } \\
\text { applications } \\
\text { acted upon } \\
\text { by lender }\end{array}$} & \multirow{2}{*}{$\begin{array}{l}\text { Unmodified } \\
\text { denial rate }\end{array}$} & \multicolumn{2}{|c|}{$\begin{array}{l}\text { Modified denial rate, by } \\
\text { modification factor }\end{array}$} & \multirow{2}{*}{$\begin{array}{l}\text { Number of } \\
\text { applications } \\
\text { acted upon } \\
\text { by lender }\end{array}$} & \multirow{2}{*}{$\begin{array}{l}\text { Unmodified } \\
\text { denial rate }\end{array}$} & \multicolumn{2}{|c|}{$\begin{array}{l}\text { Modified denial rate, by } \\
\text { modification factor }\end{array}$} \\
\hline & & & $\begin{array}{l}\text { Borrower- } \\
\text { related }\end{array}$ & $\begin{array}{l}\text { Borrower- } \\
\text { related } \\
\text { plus lender }\end{array}$ & & & $\begin{array}{l}\text { Borrower- } \\
\text { related }\end{array}$ & $\begin{array}{c}\text { Borrower- } \\
\text { related } \\
\text { plus lender }\end{array}$ \\
\hline & \multicolumn{8}{|c|}{2006} \\
\hline & \multicolumn{4}{|c|}{ H1 } & \multicolumn{4}{|c|}{$\mathrm{H} 2$} \\
\hline 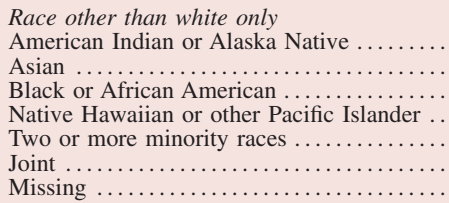 & $\begin{array}{r}17,523 \\
135,942 \\
265,677 \\
14,401 \\
1,470 \\
29,107 \\
300,767\end{array}$ & $\begin{array}{l}26.7 \\
17.3 \\
30.9 \\
23.1 \\
20.5 \\
13.8 \\
24.3\end{array}$ & $\begin{array}{l}22.6 \\
14.8 \\
27.2 \\
21.0 \\
18.8 \\
17.0 \\
23.4\end{array}$ & $\begin{array}{l}19.3 \\
14.9 \\
21.5 \\
18.3 \\
16.3 \\
14.9 \\
17.9\end{array}$ & $\begin{array}{r}17,123 \\
128,455 \\
287,491 \\
14,703 \\
1,669 \\
28,674 \\
310,302\end{array}$ & $\begin{array}{l}25.0 \\
16.8 \\
32.3 \\
23.8 \\
19.9 \\
13.4 \\
24.1\end{array}$ & $\begin{array}{l}21.7 \\
14.0 \\
28.2 \\
19.3 \\
18.0 \\
16.8 \\
23.8\end{array}$ & $\begin{array}{l}17.1 \\
14.8 \\
21.5 \\
16.6 \\
16.8 \\
14.6 \\
17.8\end{array}$ \\
\hline $\begin{array}{l}\text { White, by ethnicity } \\
\text { Hispanic white } \ldots \ldots \ldots \ldots \ldots \ldots \ldots \ldots \ldots \ldots \ldots \ldots \ldots \ldots \ldots \ldots \ldots \ldots \\
\text { Non-Hispanic white } \ldots \ldots \ldots \ldots \ldots \ldots \ldots \ldots\end{array}$ & $\begin{array}{r}357,209 \\
1,543,650\end{array}$ & $\begin{array}{l}24.7 \\
13.2\end{array}$ & $\begin{array}{l}20.0 \\
13.2\end{array}$ & $\begin{array}{l}17.5 \\
13.2\end{array}$ & $\begin{array}{r}361,957 \\
1,519,786\end{array}$ & $\begin{array}{l}26.2 \\
13.1\end{array}$ & $\begin{array}{l}20.7 \\
13.1\end{array}$ & $\begin{array}{l}17.6 \\
13.1\end{array}$ \\
\hline 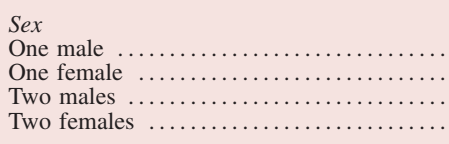 & $\begin{array}{r}915,120 \\
658,209 \\
26,074 \\
21,860\end{array}$ & $\begin{array}{l}21.3 \\
20.7 \\
19.8 \\
19.5\end{array}$ & $\begin{array}{l}21.3 \\
20.1 \\
19.8 \\
18.0\end{array}$ & $\begin{array}{l}21.3 \\
20.6 \\
19.8 \\
18.6\end{array}$ & $\begin{array}{r}918,501 \\
676,289 \\
24,431 \\
21,462\end{array}$ & $\begin{array}{l}22.1 \\
21.3 \\
18.6 \\
19.4\end{array}$ & $\begin{array}{l}22.1 \\
20.8 \\
18.6 \\
16.9\end{array}$ & $\begin{array}{l}22.1 \\
21.2 \\
18.6 \\
16.9\end{array}$ \\
\hline & \multicolumn{8}{|c|}{2007} \\
\hline & \multicolumn{4}{|c|}{$\mathrm{H} 1$} & \multicolumn{4}{|c|}{$\mathrm{H} 2$} \\
\hline 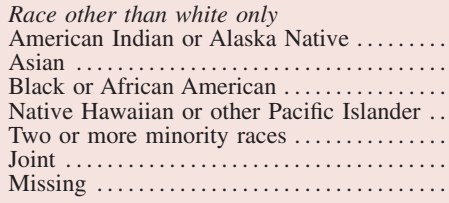 & $\begin{array}{r}12,326 \\
106,595 \\
206,186 \\
10,540 \\
1,384 \\
244,610 \\
233,947\end{array}$ & $\begin{array}{l}28.6 \\
17.1 \\
36.0 \\
28.2 \\
25.9 \\
14.7 \\
25.4\end{array}$ & $\begin{array}{l}25.1 \\
14.6 \\
31.6 \\
23.0 \\
24.7 \\
18.5 \\
24.4\end{array}$ & $\begin{array}{l}21.4 \\
15.0 \\
23.9 \\
21.1 \\
21.9 \\
15.4 \\
18.1\end{array}$ & $\begin{array}{r}10,301 \\
104,233 \\
158,701 \\
8,896 \\
1,440 \\
23,715 \\
207,299\end{array}$ & $\begin{array}{l}27.0 \\
17.7 \\
34.2 \\
26.7 \\
21.3 \\
14.4 \\
23.6\end{array}$ & $\begin{array}{l}23.8 \\
15.2 \\
29.3 \\
21.4 \\
19.3 \\
17.6 \\
21.5\end{array}$ & $\begin{array}{l}20.0 \\
15.1 \\
22.9 \\
19.5 \\
19.3 \\
15.3 \\
16.7\end{array}$ \\
\hline $\begin{array}{l}\text { White, by ethnicity } \\
\text { Hispanic white } \ldots . . . \\
\text { Non-Hispanic white }\end{array}$ & $\begin{array}{r}257,135 \\
1,307,913\end{array}$ & $\begin{array}{l}29.9 \\
13.3\end{array}$ & $\begin{array}{l}22.4 \\
13.3\end{array}$ & $\begin{array}{l}19.7 \\
13.3\end{array}$ & $\begin{array}{r}191,838 \\
1,187,866\end{array}$ & $\begin{array}{l}30.0 \\
13.2\end{array}$ & $\begin{array}{l}22.0 \\
13.2\end{array}$ & $\begin{array}{l}19.7 \\
13.2\end{array}$ \\
\hline $\begin{array}{l}\text { Sex } \\
\text { One male } \ldots \ldots \ldots \ldots \ldots \ldots \ldots \ldots \\
\text { One female } \ldots \ldots \ldots \ldots \ldots \ldots \ldots \ldots \ldots \\
\text { Two males } \ldots \ldots \ldots \ldots \ldots \ldots \ldots \ldots \\
\text { Two females } \ldots \ldots \ldots \ldots \ldots \ldots \ldots\end{array}$ & $\begin{array}{r}739,062 \\
527,172 \\
20,708 \\
18,053\end{array}$ & $\begin{array}{l}22.9 \\
22.2 \\
21.4 \\
22.1\end{array}$ & $\begin{array}{l}22.9 \\
21.7 \\
21.4 \\
20.6\end{array}$ & $\begin{array}{l}22.9 \\
22.1 \\
21.4 \\
20.2\end{array}$ & $\begin{array}{r}610,149 \\
440,646 \\
20,420 \\
17,131\end{array}$ & $\begin{array}{l}22.4 \\
20.9 \\
20.6 \\
20.0\end{array}$ & $\begin{array}{l}22.4 \\
20.6 \\
20.6 \\
18.1\end{array}$ & $\begin{array}{l}22.4 \\
21.2 \\
20.6 \\
18.7\end{array}$ \\
\hline
\end{tabular}

NoTE: Includes transition-period applications (those submitted before 2004). For explanation of modification factors, see text. See also note 1, table 18.A.

— withdrawn by the applicant

- file closed for incompleteness

- pre-approval program status (for home-purchase loans only)

— pre-approval request denied by financial institution

- pre-approval request approved but not accepted by individual

- loan amount

- loan type

- conventional

— insured by the Federal Housing Administration

- guaranteed by the Veterans Administration

- backed by the Farm Service Agency or Rural Housing Service
- lien status

- first lien

— junior lien

- unsecured

- loan purpose

- home purchase

- refinance

- home improvement

- type of purchaser (if the lender subsequently sold the loan during the year)

- Fannie Mae

- Ginnie Mae

- Freddie Mac

- Farmer Mac

- Private securitization

— Commercial bank, savings bank, or savings association 
20. Denial rates on applications, unmodified and modified for borrower- and lender-related factors, for conventional first liens on owner-occupied, one- to four-family, site-built homes, by half-year in which application was acted upon by lender and by race, ethnicity, and sex of applicant, 2006-07-Continued

B. Refinance

Percent except as noted

\begin{tabular}{|c|c|c|c|c|c|c|c|c|}
\hline \multirow[b]{2}{*}{ Race, ethnicity, and sex ${ }^{1}$} & \multirow{2}{*}{$\begin{array}{l}\text { Number of } \\
\text { applications } \\
\text { acted upon } \\
\text { by lender }\end{array}$} & \multirow{2}{*}{$\begin{array}{l}\text { Unmodified } \\
\text { denial rate }\end{array}$} & \multicolumn{2}{|c|}{$\begin{array}{l}\text { Modified denial rate, by } \\
\text { modification factor }\end{array}$} & \multirow{2}{*}{$\begin{array}{l}\text { Number of } \\
\text { applications } \\
\text { acted upon } \\
\text { by lender }\end{array}$} & \multirow{2}{*}{$\begin{array}{l}\text { Unmodified } \\
\text { denial rate }\end{array}$} & \multicolumn{2}{|c|}{$\begin{array}{l}\text { Modified denial rate, by } \\
\text { modification factor }\end{array}$} \\
\hline & & & $\begin{array}{l}\text { Borrower- } \\
\text { related }\end{array}$ & $\begin{array}{l}\text { Borrower- } \\
\text { related } \\
\text { plus lender }\end{array}$ & & & $\begin{array}{l}\text { Borrower- } \\
\text { related }\end{array}$ & $\begin{array}{l}\text { Borrower- } \\
\text { related } \\
\text { plus lender }\end{array}$ \\
\hline & \multicolumn{8}{|c|}{2006} \\
\hline & \multicolumn{4}{|c|}{$\mathrm{H} 1$} & \multicolumn{4}{|c|}{$\mathrm{H} 2$} \\
\hline 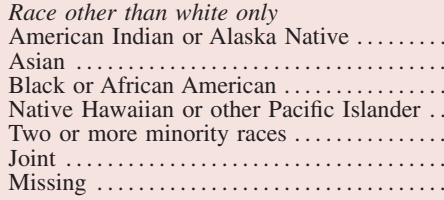 & $\begin{array}{r}31,582 \\
104,007 \\
431,030 \\
23,560 \\
2,804 \\
37,091 \\
736,949\end{array}$ & $\begin{array}{l}44.3 \\
28.3 \\
44.8 \\
35.8 \\
40.0 \\
34.0 \\
50.2\end{array}$ & $\begin{array}{l}44.8 \\
33.6 \\
46.1 \\
41.7 \\
43.0 \\
40.5 \\
51.3\end{array}$ & $\begin{array}{l}38.7 \\
35.3 \\
39.0 \\
37.8 \\
36.1 \\
35.0 \\
39.1\end{array}$ & $\begin{array}{r}32,175 \\
111,165 \\
452,812 \\
23,877 \\
3,074 \\
36,939 \\
711,665\end{array}$ & $\begin{array}{l}45.0 \\
27.1 \\
44.9 \\
37.0 \\
40.9 \\
34.1 \\
45.7\end{array}$ & $\begin{array}{l}44.2 \\
33.0 \\
46.0 \\
41.9 \\
43.4 \\
39.9 \\
47.6\end{array}$ & $\begin{array}{l}35.7 \\
33.8 \\
38.1 \\
37.0 \\
36.8 \\
33.7 \\
37.2\end{array}$ \\
\hline $\begin{array}{l}\text { White, by ethnicity } \\
\text { Hispanic white } \ldots \ldots \ldots \ldots \ldots \ldots \ldots \ldots \ldots \ldots \\
\text { Non-Hispanic white } \ldots \ldots \ldots \ldots \ldots \ldots \ldots\end{array}$ & $\begin{array}{r}387,469 \\
2,180,168\end{array}$ & $\begin{array}{l}33.3 \\
31.3\end{array}$ & $\begin{array}{l}36.4 \\
31.3\end{array}$ & $\begin{array}{l}36.7 \\
31.3\end{array}$ & $\begin{array}{r}414,344 \\
2,163,111\end{array}$ & $\begin{array}{l}33.7 \\
30.0\end{array}$ & $\begin{array}{l}37.1 \\
30.0\end{array}$ & $\begin{array}{l}35.2 \\
30.0\end{array}$ \\
\hline 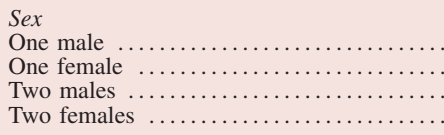 & $\begin{array}{r}1,151,237 \\
950,223 \\
25,064 \\
29,707\end{array}$ & $\begin{array}{l}38.3 \\
37.0 \\
36.5 \\
38.8\end{array}$ & $\begin{array}{l}38.3 \\
35.8 \\
36.5 \\
36.3\end{array}$ & $\begin{array}{l}38.3 \\
36.6 \\
36.5 \\
36.3\end{array}$ & $\begin{array}{r}1,172,849 \\
975,866 \\
25,806 \\
30,478\end{array}$ & $\begin{array}{l}36.9 \\
35.2 \\
36.5 \\
40.2\end{array}$ & $\begin{array}{l}36.9 \\
34.2 \\
36.5 \\
37.7\end{array}$ & $\begin{array}{l}22.1 \\
21.2 \\
36.5 \\
35.7\end{array}$ \\
\hline & \multicolumn{8}{|c|}{2007} \\
\hline & \multicolumn{4}{|c|}{ H1 } & \multicolumn{4}{|c|}{$\mathrm{H} 2$} \\
\hline 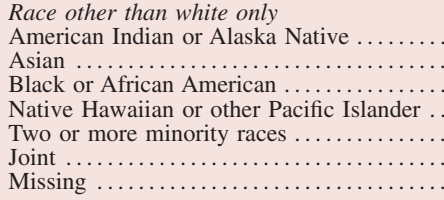 & $\begin{array}{r}32,148 \\
111,681 \\
408,342 \\
21,457 \\
3,276 \\
38,339 \\
646,545\end{array}$ & $\begin{array}{l}54.2 \\
30.1 \\
51.3 \\
43.6 \\
49.2 \\
38.9 \\
48.5\end{array}$ & $\begin{array}{l}51.0 \\
35.5 \\
51.4 \\
46.5 \\
50.4 \\
44.5 \\
49.8\end{array}$ & $\begin{array}{l}41.4 \\
36.4 \\
42.2 \\
41.3 \\
41.8 \\
37.1 \\
39.4\end{array}$ & $\begin{array}{r}27,626 \\
90,733 \\
329,444 \\
17,394 \\
2,928 \\
32,643 \\
500,917\end{array}$ & $\begin{array}{l}60.2 \\
35.6 \\
55.9 \\
49.7 \\
53.0 \\
44.5 \\
50.7\end{array}$ & $\begin{array}{l}56.1 \\
38.8 \\
56.4 \\
51.5 \\
53.9 \\
48.8 \\
49.7\end{array}$ & $\begin{array}{l}43.6 \\
39.5 \\
44.9 \\
44.6 \\
47.0 \\
40.3 \\
41.2\end{array}$ \\
\hline $\begin{array}{l}\text { White, by ethnicity } \\
\text { Hispanic white } \ldots \ldots \ldots \ldots \ldots \ldots \ldots \ldots \ldots \ldots \\
\text { Non-Hispanic white } \ldots \ldots \ldots \ldots \ldots \ldots \ldots\end{array}$ & $\begin{array}{r}377,168 \\
2,149,801\end{array}$ & $\begin{array}{l}40.1 \\
32.7\end{array}$ & $\begin{array}{l}42.0 \\
32.7\end{array}$ & $\begin{array}{l}39.8 \\
32.7\end{array}$ & $\begin{array}{r}318,369 \\
1,767,691\end{array}$ & $\begin{array}{l}47.3 \\
35.7\end{array}$ & $\begin{array}{l}46.6 \\
35.7\end{array}$ & $\begin{array}{l}43.4 \\
35.7\end{array}$ \\
\hline 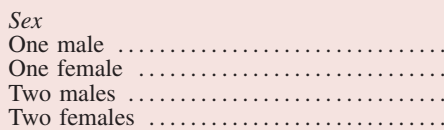 & $\begin{array}{r}1,125,730 \\
888,877 \\
25,663 \\
29,119\end{array}$ & $\begin{array}{l}40.6 \\
39.1 \\
40.1 \\
43.4\end{array}$ & $\begin{array}{l}40.6 \\
38.1 \\
40.1 \\
40.8\end{array}$ & $\begin{array}{l}40.6 \\
39.1 \\
40.1 \\
40.5\end{array}$ & $\begin{array}{r}891,020 \\
717,686 \\
22,436 \\
26,193\end{array}$ & $\begin{array}{l}44.2 \\
42.3 \\
43.1 \\
46.2\end{array}$ & $\begin{array}{l}44.2 \\
41.4 \\
43.1 \\
43.8\end{array}$ & $\begin{array}{l}44.2 \\
42.6 \\
43.1 \\
41.7\end{array}$ \\
\hline
\end{tabular}

NotE: See note to table 20.A.

- Life insurance company, credit union, mortgage bank, or finance company

- Affiliate institution

- Other type of purchaser

\section{For each applicant or co-applicant}

- race

- ethnicity

- $\operatorname{sex}$

- income relied on in credit decision

\section{For each property}

- location, by state, county, metropolitan statistical area, and census tract
- type of structure

— one- to four-family dwelling

- manufactured home

— multifamily property (dwelling with five or more units)

- occupancy status (owner occupied, non-owner occupied, or not applicable)

\section{For loans subject to price reporting}

- spread above comparable Treasury security

For loans subject to the Home Ownership and Equity Protection Act

- indicator of whether loan is subject to the Home Ownership and Equity Protection Act 


\section{APPENDIX B:}

\section{PRIVATE MORTGAGE INSURANCE DATA}

Historically, mortgage lenders have required prospective borrowers to make a down payment of at least 20 percent of a home's value before they will extend a loan to buy a home or refinance an existing loan. Such down payments are required because experience has shown that homeowners with little equity are substantially more likely to default on their mortgages. Private mortgage insurance (PMI) emerged as a response to creditors' concerns about the elevated credit risk of lending backed by little equity in a home as well as to the difficulties that some consumers encounter in accumulating sufficient savings to meet the required down payment and closing costs.

PMI protects a lender if a borrower defaults on a loan; it reduces a lender's credit risk by insuring against losses associated with default up to a contractually established percentage of the claim amount. The costs of the insurance are typically paid by the borrower through a somewhat higher interest rate on the loan.

In 1993, the Mortgage Insurance Companies of America (MICA) asked the Federal Financial Institutions Examination Council (FFIEC) to process data from PMI companies on applications for mortgage insurance and to produce disclosure statements for the public based on the data. ${ }^{36}$ The PMI data largely

36. Founded in 1973, MICA is the trade association for the PMI industry. The FFIEC prepares disclosure statements for each of the PMI companies. The statements are available at the corporate head- mirror the types of information submitted by lenders covered by HMDA. However, because the PMI companies do not receive all the information about a prospective loan from the lenders seeking insurance coverage, some HMDA items are not included in the PMI data. In particular, loan-pricing information, requests for pre-approval, and an indicator of whether a loan is subject to the Home Ownership and Equity Protection Act are unavailable in the PMI data.

The seven PMI companies that issued PMI during 2007 submitted data to the FFIEC through MICA. In total, these companies acted on nearly 2 million applications for insurance: 1.4 million applications to insure mortgages for purchasing homes and about 540,000 applications to insure mortgages for refinancing existing mortgages. PMI companies approved 92 percent of the applications they received. Approval rates for PMI companies are notably higher than they are for mortgage lenders because lenders applying for PMI are familiar with the underwriting standards used by the PMI companies and generally submit applications for insurance coverage only if the applications are likely to be approved.

quarters of each company and at a central depository in each metropolitan statistical area (MSA) in which HMDA data are held. The central depository also holds aggregate data for all the PMI companies active in that MSA. In addition, the PMI data are available from the FFIEC at www.ffiec.gov/reports.htm. 